\title{
Working
}

Paper 
The Chicago Plan Revisited

Jaromir Benes and Michael Kumhof 


\title{
IMF Working Paper
}

\author{
Research Department
}

\section{The Chicago Plan Revisited}

\section{Prepared by Jaromir Benes and Michael Kumhof}

\author{
Authorized for distribution by Douglas Laxton
}

August 2012

\section{This Working Paper should not be reported as representing the views of the IMF.} The views expressed in this Working Paper are those of the author(s) and do not necessarily represent those of the IMF or IMF policy. Working Papers describe research in progress by the author(s) and are published to elicit comments and to further debate.

\begin{abstract}
At the height of the Great Depression a number of leading U.S. economists advanced a proposal for monetary reform that became known as the Chicago Plan. It envisaged the separation of the monetary and credit functions of the banking system, by requiring $100 \%$ reserve backing for deposits. Irving Fisher (1936) claimed the following advantages for this plan: (1) Much better control of a major source of business cycle fluctuations, sudden increases and contractions of bank credit and of the supply of bank-created money.

(2) Complete elimination of bank runs. (3) Dramatic reduction of the (net) public debt.

(4) Dramatic reduction of private debt, as money creation no longer requires simultaneous debt creation. We study these claims by embedding a comprehensive and carefully calibrated model of the banking system in a DSGE model of the U.S. economy. We find support for all four of Fisher's claims. Furthermore, output gains approach 10 percent, and steady state inflation can drop to zero without posing problems for the conduct of monetary policy.
\end{abstract}

JEL Classification Numbers:E44, E52, G21

Keywords: Chicago Plan; Chicago School of Economics; 100\% reserve banking; bank lending; lending risk; private money creation; bank capital adequacy; government debt; private debt; boom-bust cycles.

Authors’ E-Mail Addresses: jbenes@imf.org; mkumhof@imf.org 


\section{Contents}

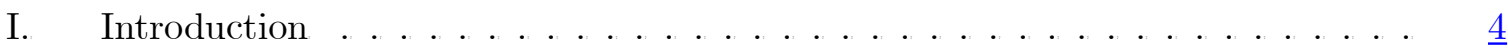

II. The Chicago Plan in the History of Monetary Thought . . . . . . . . . . . . 12

A. Government versus Private Control over Money Issuance . . . . . . . . $\underline{12}$

B. The Chicago Plan .................... . . 17

III. The Model under the Current Monetary System . . . . . . . . . . . . . . . . $\underline{20}$

A. Banks . . . . . . . . . . . . . . . . . . . . . . . 20

B. Lending Technologies ... . . . . . . . . . . . . . . . . . . . $\underline{24}$

C. Transactions Cost Technologies ................. . . . . $\underline{26}$

D. Equity Ownership and Dividends ............... . . $\underline{26}$

E. Unconstrained Households . . . . . . . . . . . . . . . . . . $\underline{27}$

F. Constrained Households . . . . . . . . . . . . . . . . . . $\underline{28}$

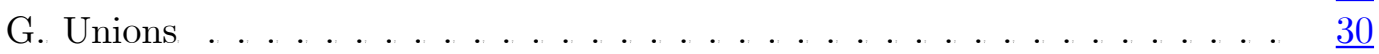

H. Manufacturers . . . . . . . . . . . . . . . . . . . . . . . . . . . . . . . . . . . . .

I. Capital Goods Producers . . . . . . . . . . . . . . . . . . . . $\underline{31}$

J. Capital Investment Funds . . . . . . . . . . . . . . . . . . . . . $3 \underline{31}$

K. Government . . . . . . . . . . . . . . . . . . . . . . . . . . . . . . . . . . . . . . .

1. Monetary Policy . . . . . . . . . . . . . . . . . . . . . . . . . . . . . . . . .

2. Prudential Policy ... . . . . . . . . . . . . . . . . . . . . $\underline{32}$

3. Fiscal Policy . . . . . . . . . . . . . . . . . . . . . $\underline{32}$

4. Government Budget Constraint . . . . . . . . . . . . . $\underline{33}$

L. Market Clearing . . . . . . . . . . . . . . . . . . . . . $\underline{33}$

IV. The Model under the Chicago Plan . . . . . . . . . . . . . . . . $\underline{33}$

A. Banks . . . . . . . . . . . . . . . . . . . . . . . . 33

B. Households . . . . . . . . . . . . . . . . . . . . . . . . . . . . . . . . . . . . . . . .

C. Manufacturers . . . . . . . . . . . . . . . . . . . . $\underline{37}$

D. Government . . . . . . . . . . . . . . . . . . . . . . . . . . . . . . .

1. Monetary Policy . . . . . . . . . . . . . . . . . . . . $\underline{37}$

2. Prudential Policy . . . . . . . . . . . . . . . . . . . . . . . . . . . . . . . . . . . . .

3. Fiscal Policy . . . . . . . . . . . . . . . . . . . $\underline{40}$

4. Government Budget Constraint . . . . . . . . . . . . . . $\underline{41}$

5. Controlling Boom-Bust Cycles - Additional Considerations . . . . . $\underline{42}$

V. Calibration .................................

VI. Transition to the Chicago Plan . . . . . . . . . . . . . $\underline{49}$

VII. Credit Booms and Busts Pre-Transition and Post-Transition . . . . . . . $\underline{52}$

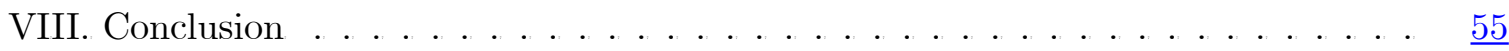

References ................................... $\underline{57}$ 
Figures

1. Changes in Bank Balance Sheet in Transition Period (percent of GDP) . . . . $\underline{64}$

2. Changes in Government Balance Sheet in Transition Period (percent of GDP) $\underline{65}$

3. Changes in Bank Balance Sheet - Details (percent of GDP) . . . . . . . $\underline{66}$

4. Transition to Chicago Plan - Bank Balance Sheets . . . . . . . . . . . . $\underline{67}$

5. Transition to Chicago Plan - Main Macroeconomic Variables . . . . . . . . $\underline{68}$

6. Transition to Chicago Plan - Fiscal Variables . . . . . . . . . . . . . $\underline{69}$

7. Business Cycle Properties Pre-Transition versus Post-Transition . . . . . . . $\underline{70}$ 


\section{Introduction}

The decade following the onset of the Great Depression was a time of great intellectual ferment in economics, as the leading thinkers of the time tried to understand the apparent failures of the existing economic system. This intellectual struggle extended to many domains, but arguably the most important was the field of monetary economics, given the key roles of private bank behavior and of central bank policies in triggering and prolonging the crisis.

During this time a large number of leading U.S. macroeconomists supported a fundamental proposal for monetary reform that later became known as the Chicago Plan, after its strongest proponent, professor Henry Simons of the University of Chicago. It was also supported, and brilliantly summarized, by Irving Fisher of Yale University, in Fisher (1936). The key feature of this plan was that it called for the separation of the monetary and credit functions of the banking system, first by requiring $100 \%$ backing of deposits by government-issued money, and second by ensuring that the financing of new bank credit can only take place through earnings that have been retained in the form of government-issued money, or through the borrowing of existing government-issued money from non-banks, but not through the creation of new deposits, ex nihilo, by banks.

Fisher (1936) claimed four major advantages for this plan. First, preventing banks from creating their own funds during credit booms, and then destroying these funds during subsequent contractions, would allow for a much better control of credit cycles, which were perceived to be the major source of business cycle fluctuations. Second, $100 \%$ reserve backing would completely eliminate bank runs. Third, allowing the government to issue money directly at zero interest, rather than borrowing that same money from banks at interest, would lead to a reduction in the interest burden on government finances and to a dramatic reduction of (net) government debt, given that irredeemable government-issued money represents equity in the commonwealth rather than debt. Fourth, given that money creation would no longer require the simultaneous creation of mostly private debts on bank balance sheets, the economy could see a dramatic reduction not only of government debt but also of private debt levels.

We take it as self-evident that if these claims can be verified, the Chicago Plan would indeed represent a highly desirable policy. Profound thinkers like Fisher, and many of his most illustrious peers, based their insights on historical experience and common sense, and were hardly deterred by the fact that they might not have had complete economic models that could formally derive the welfare gains of avoiding credit-driven boom-bust cycles, bank runs, and high debt levels. We do in fact believe that this made them better, not worse, thinkers about issues of the greatest importance for the common good. But we can say more than this. The recent empirical evidence of Reinhart and Rogoff (2009) documents the high costs of boom-bust credit cycles and bank runs throughout history. And the recent empirical evidence of Schularick and Taylor (2012) is supportive of Fisher's view that high debt levels are a very important predictor of major crises. The latter finding is also consistent with the theoretical work of Kumhof and Rancière (2010), who show how very high debt levels, such as those observed just prior to the Great Depression and the Great Recession, can lead to a higher probability of financial and real crises. 
We now turn to a more detailed discussion of each of Fisher's four claims concerning the advantages of the Chicago Plan. This will set the stage for a first illustration of the implied balance sheet changes, which will be provided in Figures 1 and 2 .

The first advantage of the Chicago Plan is that it permits much better control of what Fisher and many of his contemporaries perceived to be the major source of business cycle fluctuations, sudden increases and contractions of bank credit that are not necessarily driven by the fundamentals of the real economy, but that themselves change those fundamentals. In a financial system with little or no reserve backing for deposits, and with government-issued cash having a very small role relative to bank deposits, the creation of a nation's broad monetary aggregates depends almost entirely on banks' willingness to supply deposits. Because additional bank deposits can only be created through additional bank loans, sudden changes in the willingness of banks to extend credit must therefore not only lead to credit booms or busts, but also to an instant excess or shortage of money, and therefore of nominal aggregate demand. By contrast, under the Chicago Plan the quantity of money and the quantity of credit would become completely independent of each other. This would enable policy to control these two aggregates independently and therefore more effectively. Money growth could be controlled directly via a money growth rule. The control of credit growth would become much more straightforward because banks would no longer be able, as they are today, to generate their own funding, deposits, in the act of lending, an extraordinary privilege that is not enjoyed by any other type of business. Rather, banks would become what many erroneously believe them to be today, pure intermediaries that depend on obtaining outside funding before being able to lend. Having to obtain outside funding rather than being able to create it themselves would much reduce the ability of banks to cause business cycles due to potentially capricious changes in their attitude towards credit risk.

The second advantage of the Chicago Plan is that having fully reserve-backed bank deposits would completely eliminate bank runs, thereby increasing financial stability, and allowing banks to concentrate on their core lending function without worrying about instabilities originating on the liabilities side of their balance sheet. The elimination of bank runs will be accomplished if two conditions hold. First, the banking system's monetary liabilities must be fully backed by reserves of government-issued money, which is of course true under the Chicago Plan. Second, the banking system's credit assets must be funded by non-monetary liabilities that are not subject to runs. This means that policy needs to ensure that such liabilities cannot become near-monies. The literature of the 1930s and 1940s discussed three institutional arrangements under which this can be accomplished. The easiest is to require that banks fund all of their credit assets with a combination of equity and loans from the government treasury, and completely without private debt instruments. This is the core element of the version of the Chicago Plan considered in this paper, because it has a number of advantages that go beyond decisively preventing the emergence of near-monies. By itself this would mean that there is no lending at all between private agents. However, this can be insufficient when private agents exhibit highly heterogeneous initial debt levels. In that case the treasury loans solution can be accompanied by either one or both of the other two institutional arrangements. One is debt-based investment trusts that are true intermediaries, in that the trust can only lend government-issued money to net borrowers after net savers have first deposited these funds in exchange for debt instruments issued by the trust. But there is a risk that 
these debt instruments could themselves become near-monies unless there are strict and effective regulations. This risk would be eliminated under the remaining alternative, investment trusts that are funded exclusively by net savers' equity investments, with the funds either lent to net borrowers, or invested as equity if this is feasible (it may not be feasible for household debtors). We will briefly return to the investment trust alternatives below, but they are not part of our formal analysis because our model does not feature heterogeneous debt levels within the four main groups of bank borrowers.

The third advantage of the Chicago Plan is a dramatic reduction of (net) government debt. The overall outstanding liabilities of today's U.S. financial system, including the shadow banking system, are far larger than currently outstanding U.S. Treasury liabilities. Because under the Chicago Plan banks have to borrow reserves from the treasury to fully back these large liabilities, the government acquires a very large asset vis-à-vis banks, and government debt net of this asset becomes highly negative. Governments could leave the separate gross positions outstanding, or they could buy back government bonds from banks against the cancellation of treasury credit. Fisher had the second option in mind, based on the situation of the 1930s, when banks held the major portion of outstanding government debt. But today most U.S. government debt is held outside U.S. banks, so that the first option is the more relevant one. The effect on net debt is of course the same, it drops dramatically.

In this context it is critical to realize that the stock of reserves, or money, newly issued by the government is not a debt of the government. The reason is that fiat money is not redeemable, in that holders of money cannot claim repayment in something other than money. ${ }^{1}$ Money is therefore properly treated as government equity rather than government debt, which is exactly how treasury coin is currently treated under U.S. accounting conventions (Federal Accounting Standards Advisory Board (2012)).

The fourth advantage of the Chicago Plan is the potential for a dramatic reduction of private debts. As mentioned above, full reserve backing by itself would generate a highly negative net government debt position. Instead of leaving this in place and becoming a large net lender to the private sector, the government has the option of spending part of the windfall by buying back large amounts of private debt from banks against the cancellation of treasury credit. Because this would have the advantage of establishing low-debt sustainable balance sheets in both the private sector and the government, it is plausible to assume that a real-world implementation of the Chicago Plan would involve at least some, and potentially a very large, buy-back of private debt. In the simulation of the Chicago Plan presented in this paper we will assume that the buy-back covers all private bank debt except loans that finance investment in physical capital.

We study Fisher's four claims by embedding a comprehensive and carefully calibrated model of the U.S. financial system in a state-of-the-art monetary DSGE model of the U.S. economy. ${ }^{2}$ We find strong support for all four of Fisher's claims, with the potential for much smoother business cycles, no possibility of bank runs, a large reduction of debt levels across the economy, and a replacement of that debt by debt-free government-issued money.

\footnotetext{
${ }^{1}$ Furthermore, in a growing economy the government will never have a need to voluntarily retire money to maintain price stability, as the economy's monetary needs increase period after period.

${ }^{2}$ To our knowledge this is the first attempt to model the Chicago Plan in this way. Yamaguchi (2011) discusses the Chicago Plan using a systems dynamics approach.
} 
Furthermore, none of these benefits come at the expense of diminishing the core useful functions of a private financial system. Under the Chicago Plan private financial institutions would continue to play a key role in providing a state-of-the-art payments system, facilitating the efficient allocation of capital to its most productive uses, and facilitating intertemporal smoothing by households and firms. Credit, especially socially useful credit that supports real physical investment activity, would continue to exist. What would cease to exist however is the proliferation of credit created, at the almost exclusive initiative of private institutions, for the sole purpose of creating an adequate money supply that can easily be created debt-free.

At this point in the paper it may not be straightforward for the average reader to comprehend the nature of the balance sheet changes implied by the Chicago Plan. A complete analysis requires a thorough prior discussion of both the model and of its calibration, and is therefore only possible much later in the paper. But we feel that at least a preliminary presentation of the main changes is essential to aid in the comprehension of what follows. In Figures 1 and 2 we therefore present the changes in bank and government balance sheets that occur in the single transition period of our simulated model. The figures ignore subsequent changes as the economy approaches a new steady state, but those are small compared to the initial changes. In both figures quantities reported are in percent of GDP. Compared to Figure 3, which shows the precise results, the numbers in Figure 1 are rounded, in part to avoid having to discuss unnecessary details.

As shown in the left column of Figure 1, the balance sheet of the consolidated financial system prior to the implementation of the Chicago Plan is equal to $200 \%$ of GDP, with equity and deposits equal to $16 \%$ and $184 \%$ of GDP. Banks' assets consist of government bonds equal to $20 \%$ of GDP, investment loans equal to $80 \%$ of GDP, and other loans (mortgage loans, consumer loans, working capital loans) equal to $100 \%$ of GDP. The implementation of the plan is assumed to take place in one transition period, which can be broken into two separate stages. First, as shown in the middle column of Figure 1, banks have to borrow from the treasury to procure the reserves necessary to fully back their deposits. As a result both treasury credit and reserves increase by $184 \%$ of GDP. Second, as shown in the right column of Figure 1, the principal of all bank loans to the government (20\% of GDP), and of all bank loans to the private sector except investment loans $(100 \%$ of GDP), is cancelled against treasury credit. For government debt the cancellation is direct, while for private debt the government transfers treasury credit balances to restricted private accounts that can only be used for the purpose of repaying outstanding bank loans. Furthermore, banks pay out part of their equity to keep their net worth in line with now much reduced official capital adequacy requirements, with the government making up the difference of $7 \%$ of GDP by injecting additional treasury credit. The solid line in the balance sheet in the right column of Figure 1 represents the now strict separation between the monetary and credit functions of the banking system. Money remains nearly unchanged, but it is now fully backed by reserves. Credit consists only of investment loans, which are financed by a reduced level of equity equal to $9 \%$ of GDP, and by what is left of treasury credit, 71\% of GDP, after the buy-backs of government and private debts and the injection of additional credit following the equity payout.

Figure 2 illustrates the balance sheet of the government, which prior to the Chicago Plan consists of government debt equal to $80 \%$ of GDP, with unspecified other assets used as the balancing item. The issuance of treasury credit equal to $184 \%$ of GDP represents a 
large new financial asset of the government, while the issuance of an equal amount of reserves, in other words of money, represents new government equity. The cancellation of private debts reduces both treasury credit and government equity by $100 \%$ of GDP. The government is assumed to tax away the equity payout of banks to households before injecting those funds back into banks as treasury credit. This increases both treasury credit and government equity by $7 \%$ of GDP. Finally, the cancellation of bank-held government debt reduces both government debt and treasury credit by $20 \%$ of GDP.

To summarize, our analysis finds that the government is left with a much lower, in fact negative, net debt burden. It gains a large net equity position due to money issuance, despite the fact that it spends a large share of the one-off seigniorage gains from money issuance on the buy-back of private debts. These buy-backs in turn mean that the private sector is left with a much lower debt burden, while its deposits remain unchanged. Bank runs are obviously impossible in this world. These results, whose analytical foundations will be derived in the rest of the paper, support three out of Fisher's (1936) four claims in favor of the Chicago Plan. The remaining claim, concerning the potential for smoother business cycles, will be verified towards the end of the paper, once the full model has been developed. But we can go even further, because our general equilibrium analysis highlights two additional advantages of the Chicago Plan.

First, in our calibration the Chicago Plan generates longer-term output gains approaching 10 percent. This happens for three main reasons. Monetary reform leads to large reductions of real interest rates, as lower net debt levels lead investors to demand lower spreads on government and private debts. It permits much lower distortionary tax rates, due to the beneficial effects of much higher seigniorage income (despite lower inflation) on the government budget. And finally it leads to lower credit monitoring costs, because scarce resources no longer have to be spent on monitoring loans whose sole purpose was to create an adequate money supply that can easily be produced debt-free.

Second, steady state inflation can drop to zero without posing problems for the conduct of monetary policy. The reason is that the separation of the money and credit functions of the banking system allows the government to effectively control multiple policy instruments, including a nominal money growth rule that regulates the money supply, a Basel-III-style countercyclical bank capital adequacy rule that controls the quantity of bank lending, and finally an interest rate rule that controls the price of government credit to banks. The latter replaces the conventional Taylor rule for the interest rate on government debt. One critical implication of this different monetary environment is that liquidity traps cannot exist, for two reasons. First, the aggregate quantity of broad money in private agents' hands can be directly increased by the policymaker, without depending on banks' willingness to lend. And second, because the interest rate on treasury credit is not an opportunity cost of money for asset investors, but rather a borrowing rate for a credit facility that is only accessible to banks for the specific purpose of funding physical investment projects, it can become negative without any practical problems. In other words, a zero lower bound does not apply to this rate, which makes it feasible to keep steady state inflation at zero without worrying about the fact that nominal policy rates are in that case more likely to reach zero or negative values. ${ }^{3}$

\footnotetext{
${ }^{3}$ Zero steady state inflation has been found to be desirable in a number of recent models of the monetary business cycle (Schmitt-Grohé and Uribe (2004)).
} 
The ability to live with significantly lower steady state inflation also answers the somewhat confused claim of opponents of an exclusive government monopoly on money issuance, namely that such a system, and especially the initial injection of new government-issued money, would be highly inflationary. There is nothing in our theory that supports this claim. And as we will see in section II, there is also virtually nothing in the monetary history of ancient societies and of Western nations that supports this claim.

The critical feature of our theoretical model is that it exhibits the key function of banks in modern economies, which is not their largely incidental function as financial intermediaries between depositors and borrowers, but rather their central function as creators and destroyers of money. ${ }^{4}$ A realistic model needs to reflect the fact that under the present system banks do not have to wait for depositors to appear and make funds available before they can on-lend, or intermediate, those funds. Rather, they create their own funds, deposits, in the act of lending. This fact can be verified in the description of the money creation system in many central bank statements ${ }^{5}$, and it is obvious to anybody who has ever lent money and created the resulting book entries. ${ }^{6}$ In other words, bank liabilities are not macroeconomic savings, even though at the microeconomic level they can appear as such. Savings are a state variable, so that by relying entirely on intermediating slow-moving savings, banks would be unable to engineer the rapid lending booms and busts that are frequently observed in practice. Rather, bank liabilities are money that can be created and destroyed at a moment's notice. The critical importance of this fact appears to have been lost in much of the modern macroeconomics literature on banking, with the exception of Werner (2005), and the partial exception of Christiano et al. (2011). ${ }^{7}$ Our model generates this feature in a number of ways. First, it introduces agents who have to borrow for the sole purpose of generating sufficient deposits for their transactions purposes. This means that they simultaneously borrow from and deposit with banks, as is true for many households and firms in the real world. Second, the model introduces financially unconstrained agents who do not borrow from banks. Their savings consist of multiple assets including a fixed asset referred to as land, government bonds and deposits. This means that a sale of mortgageable fixed assets from these agents to credit-constrained agents (or of government bonds to banks) results in new bank credit, and thus in the creation of new deposits that are created for the purpose of paying for

\footnotetext{
${ }^{4}$ The relative importance of these two features can be illustrated with a very simple thought experiment: Assume an economy with banks and a single homogenous group of non-bank private agents that has a transactions demand for money. In this economy there is no intermediation whatsoever, yet banks remain critical. Their function is to create the money supply through the mortgaging of private agents' assets. We have verified that such a model economy works very similarly to the one presented in this paper, which features several distinct groups of non-bank private agents.

${ }^{5}$ Berry et al. (2007), which was written by a team from the Monetary Analysis Division of the Bank of England, states: "When banks make loans, they create additional deposits for those that have borrowed the money." Keister and McAndrews (2009), staff economists at the Federal Reserve Bank of New York, write: "Suppose that Bank A gives a new loan of $\$ 20$ to Firm X, which continues to hold a deposit account with Bank A. Bank A does this by crediting Firm X's account by $\$ 20$. The bank now has a new asset (the loan to Firm X) and an offsetting liability (the increase in Firm X's deposit at the bank). Importantly, Bank A still has [unchanged] reserves in its account. In other words, the loan to Firm X does not decrease Bank A's reserve holdings at all." Putting this differently, the bank does not lend out reserves (money) that it already owns, rather it creates new deposit money ex nihilo.

${ }^{6}$ This includes one of the authors of this paper.

${ }^{7}$ We emphasize that this exception is partial, because while bank deposits in Christiano et al. (2011) are modelled as money, they are also, with the empirically insignificant exception of a possible substitution into cash, modelled as representing household savings. The latter is not true in our model.
} 
those assets. Third, even for conventional deposit-financed investment loans the transmission is from lending to savings and not the reverse. When banks decide to lend more for investment purposes, say due to increased optimism about business conditions, they create additional purchasing power for investors by crediting their accounts, and it is this purchasing power that makes the actual investment, and thus saving ${ }^{8}$, possible. Finally, the issue can be further illuminated by looking at it from the vantage point of depositors. We will assume, based on empirical evidence, that the interest rate sensitivity of deposit demand is high at the margin. Therefore, if depositors decided, for a given deposit interest rate, that they wanted to start depositing additional funds in banks, without bankers wanting to make additional loans, the end result would be virtually unchanged deposits and loans. The reason is that banks would start to pay a slightly lower deposit interest rate, and this would be sufficient to strongly reduce deposit demand without materially affecting funding costs and therefore the volume of lending. The final decision on the quantity of deposit money in the economy is therefore almost exclusively made by banks, and is based on their optimism about business conditions.

Our model completely omits two other monetary magnitudes, cash outside banks and bank reserves held at the central bank. This is because it is privately created deposit money that plays the central role in the current U.S. monetary system, while government-issued money plays a quantitatively and conceptually negligible role. It should be mentioned that both private and government-issued monies are fiat monies, because the acceptability of bank deposits for commercial and official transactions has had to first be decreed by law. As we will argue in section II, virtually all monies throughout history, including precious metals, have derived most or all of their value from government fiat rather than from their intrinsic value.

Rogoff (1998) examines U.S. dollar currency outside banks for the late 1990s. He concludes that it was equal to around 5\% of GDP for the United States, but that $95 \%$ of this was held either by foreigners and/or by the underground economy. This means that currency outside banks circulating in the formal U.S. economy equalled only around $0.25 \%$ of GDP, while we will find that the current transactions-related liabilities of the U.S. financial system, including the shadow banking system, are equal to around 200\% of GDP.

Bank reserves held at the central bank have also generally been negligible in size, except of course after the onset of the 2008 financial crisis. But this quantitative point is far less important than the recognition that they do not play any meaningful role in the determination of wider monetary aggregates. The reason is that the "deposit multiplier" of the undergraduate economics textbook, where monetary aggregates are created at the initiative of the central bank, through an initial injection of high-powered money into the banking system that gets multiplied through bank lending, turns the actual operation of the monetary transmission mechanism on its head. This should be absolutely clear under the current inflation targeting regime, where the central bank controls an interest rate and must be willing to supply as many reserves as banks demand at that rate. But as shown by Kydland and Prescott (1990), the availability of central bank reserves did not even constrain banks during the period, in the 1970s and 1980s, when the central bank did in fact officially target monetary aggregates. ${ }^{9}$ These authors show that broad monetary

\footnotetext{
${ }^{8}$ In a closed economy saving must equal investment.

${ }^{9}$ Carpenter and Demiralp (2010), in a Federal Reserve Board working paper, have found the same result,
} 
aggregates, which are driven by banks' lending decisions, led the economic cycle, while narrow monetary aggregates, most importantly reserves, lagged the cycle. In other words, at all times, when banks ask for reserves, the central bank obliges. Reserves therefore impose no constraint. The deposit multiplier is simply, in the words of Kydland and Prescott (1990), a myth. ${ }^{10}$ And because of this, private banks are almost fully in control of the money creation process.

Apart from the central role of endogenous money, other features of our banking model are based on Benes and Kumhof (2011). This work differs from other recent papers on banking along several important dimensions. First, banks have their own balance sheet and net worth, and their profits and net worth are exposed to non-diversifiable aggregate risk determined endogenously on the basis of optimal debt contracts. ${ }^{11}$ Second, banks are lenders rather than holders of risky equity. ${ }^{12}$ Third, bank lending is based on the loan contract of Bernanke, Gertler and Gilchrist (1999), but with the crucial difference that lending is risky due to non-contingent lending interest rates. This implies that banks can make losses if a larger number of loans defaults than was expected at the time of setting the lending rate. Fourth, bank capital is subject to regulation that closely replicates the features of the Basel regulatory framework, including costs of violating minimum capital adequacy regulations. Capital buffers arise as an optimal equilibrium phenomenon resulting from the interaction of optimal debt contracts, endogenous losses and regulation. ${ }^{13}$ To maintain capital buffers, banks respond to loan losses by raising their lending rate in order to rebuild their net worth, with adverse effects for the real economy. Fifth, acquiring fresh capital is subject to market imperfections. This is a necessary condition for capital adequacy regulation to have non-trivial effects, and for the capital buffers to exist. We use the "extended family" approach of Gertler and Karadi (2010), whereby bankers (and also non-financial manufacturers and entrepreneurs) transfer part of their accumulated equity positions to the household budget constraint at an exogenously fixed rate. This is closely related to the original approach of Bernanke, Gertler and Gilchrist (1999), and to the dividend policy function of Aoki, Proudman and Vlieghe (2004).

The rest of the paper is organized as follows. Section II contains a survey of the literature on monetary history and monetary thought leading up to the Chicago Plan. Section III presents an outline of the model under the current monetary system. Section IV presents the model under the Chicago Plan. Section V discusses model calibration. Section VI studies impulse responses that simulate a dynamic transition between the current monetary system and the Chicago Plan, which allows us to analyze three of the four above-mentioned claims in favor of the Chicago Plan made by Fisher (1936). The remaining claim, regarding the more effective stabilization of bank-driven business cycles, is studied in Section VII. Section VIII concludes.

\footnotetext{
using more recent data and a different methodology.

${ }^{10}$ This is of course the reason why quantitative easing, at least the kind that works by making greater reserves available to banks and not the public, can be ineffective if banks decide that lending remains too risky.

${ }^{11}$ Christiano, Motto and Rostagno (2010) and Curdia and Woodford (2010) focus exclusively on how the price of credit affects real activity.

${ }^{12}$ Gertler and Karadi (2010) and Angeloni and Faia (2009) make the latter assumption.

${ }^{13}$ Van den Heuvel (2008) models capital adequacy as a continously binding constraint. Gerali et al. (2010) use a quadratic cost short-cut.
} 


\section{The Chicago Plan in the History of Monetary Thought}

\section{A. Government versus Private Control over Money Issuance}

The monetary historian Alexander Del Mar (1895) writes: "As a rule political economists do not take the trouble to study the history of money; it is much easier to imagine it and to deduce the principles of this imaginary knowledge." Del Mar wrote more than a century ago, but this statement still applies today. An excellent example is the textbook explanation for the origins of money, which holds that money arose in private trading transactions, to overcome the double coincidence of wants problem of barter. ${ }^{14}$ As shown by Graeber (2011), on the basis of extensive anthropological and historical evidence that goes back millennia, there is not a shred of evidence to support this story. Barter was virtually nonexistent in primitive and ancient societies, and instead the first commercial transactions took place on the basis of elaborate credit systems whose denomination was typically in agricultural commodities, including cattle, grain by weight, and tools. Furthermore, Graeber (2011), Zarlenga (2002) and the references cited therein provide plenty of evidence that these credit systems, and the much later money systems, had their origins in the needs of the state (Ridgeway (1892)), of religious/temple institutions (Einzig (1966), Laum (1924)) and of social ceremony (Quiggin (1949)), and not in the needs of private trading relationships.

Any debate on the origins of money is not of merely academic interest, because it leads directly to a debate on the nature of money, which in turn has a critical bearing on arguments as to who should control the issuance of money. Specifically, the private trading story for the origins of money has time and again, starting at least with Adam Smith (1776), been used as an argument for the private issuance and control of money. Until recent times this has mainly taken the form of monetary systems based on precious metals, especially under free coinage of bullion into coins. Even though there can at times be heavy government involvement in such systems, the fact is that in practice precious metals tended to accumulate privately in the hands of the wealthy, who would then lend them out at interest. Since the thirteenth century this precious-metals-based system has, in Europe, been accompanied, and increasingly supplanted, by the private issuance of bank money, more properly called credit. On the other hand, the historically and anthropologically correct state/institutional story for the origins of money is one of the arguments supporting the government issuance and control of money under the rule of law. In practice this has mainly taken the form of interest-free issuance of notes or coins, although it could equally take the form of electronic deposits.

There is another issue that tends to get confused with the much more fundamental debate concerning the control over the issuance of money, namely the debate over "real" precious-metals-backed money versus fiat money. As documented in Zarlenga (2002), this debate is mostly a diversion, because even during historical regimes based on precious metals the main reason for the high relative value of precious metals was precisely their role as money, which derives from government fiat and not from the intrinsic qualities of the metals. ${ }^{15}$ These matters are especially confused in Smith (1776), who takes a

\footnotetext{
${ }^{14}$ A typical early example of this claim is found in Menger (1892).

${ }^{15}$ For example, in many of the ancient Greek societies gold was not intrinsically valuable due to scarcity,
} 
primitive commodity view of money despite the fact that at his time the then private Bank of England had long since started to issue a fiat currency whose value was essentially unrelated to the production cost of precious metals. Furthermore, as Smith certainly knew, both the Bank of England and private banks were creating checkable book credits in accounts for borrowing customers who had not made any deposits of coin (or even of bank notes).

The historical debate concerning the nature and control of money is the subject of Zarlenga (2002), a masterful work that traces this debate back to ancient Mesopotamia, Greece and Rome. Like Graeber (2011), he shows that private issuance of money has repeatedly led to major societal problems throughout recorded history, due to usury associated with private debts. ${ }^{16}$ Zarlenga does not adopt the common but simplistic definition of usury as the charging of "excessive interest", but rather as "taking something for nothing" through the calculated misuse of a nation's money system for private gain. Historically this has taken two forms. The first form of usury is the private appropriation of the convenience yield of a society's money. Private money has to be borrowed into existence at a positive interest rate, while the holders of that money, due to the non-pecuniary benefits of its liquidity, are content to receive no or very low interest. Therefore, while part of the interest difference between lending rates and rates on money is due to a lending risk premium, another large part is due to the benefits of the liquidity services of money. This difference is privately appropriated by the small group that owns the privilege to privately create money. This is a privilege that, due to its enormous benefits, is often originally acquired as a result of intense rent-seeking behavior. Zarlenga (2002) documents this for multiple historical episodes. We will return to the issue of the interest difference between lending and deposit rates in calibrating our theoretical model. The second form of usury is the ability of private creators of money to manipulate the money supply to their benefit, by creating an abundance of credit and thus money at times of economic expansion and thus high goods prices, followed by a contraction of credit and thus money at times of economic contraction and thus low goods prices. A typical example is the harvest cycle in ancient farming societies, but Zarlenga (2002), Del Mar (1895), and the works cited therein contain numerous other historical examples where this mechanism was at work. It repeatedly led to systemic borrower defaults, forfeiture of collateral, and therefore the concentration of wealth in the hands of lenders. For the macroeconomic consequences it matters little whether this represents deliberate and malicious manipulation, or whether it is an inherent feature of a system based on private money creation. We will return to this in our theoretical model, too.

A discussion of the crises brought on by excessive debt in ancient Mesopotamia is contained in Hudson and van de Mierop (2002). It was this experience, acquired over millennia, that led to the prohibition of usury and/or to periodic debt forgiveness ("wiping the slate clean") in the sacred texts of the main Middle Eastern religions. The earliest known example of such debt crises in Greek history are the 599 BC reforms of Solon, which were a response to a severe debt crisis of small farmers, brought on by the

as temples had accumulated vast amounts over centuries. But gold coins were nevertheless highly valued, due to public fiat declaring them to be money. A more recent example is the collapse of the price of silver relative to gold following the widespread demonetization of silver that started in the $1870 \mathrm{~s}$.

${ }^{16}$ Reinhart and Rogoff (2009) contains an even more extensive compilation of historical financial crises. However, unlike Zarlenga (2002) and Del Mar (1895), these authors do not focus on the role of private versus public monetary control, the central concern of this paper. 
charging of interest on coinage by a wealthy oligarchy. It is extremely illuminating to realize that Solon's reforms, at this very early time, already contained many elements of what Henry Simons (1948), a principal proponent of the Chicago Plan, would later refer to as the "financial good society". First, there was widespread debt cancellation, and the restitution of lands that had been seized by creditors. Second, agricultural commodities were monetized by setting official monetary floor prices for them. Because the source of loan repayments for agricultural debtors was their output of these commodities, this turned debt finance into something closer to equity finance. Third, Solon provided much more plentiful government-issued, debt-free coinage that reduced the need for private debts. Solon's reforms were so successful that, 150 years later, the early Roman republic sent a delegation to Greece to study them. They became the foundation of the Roman monetary system from 454 BC (Lex Aternia) until the time of the Punic wars (Peruzzi (1985)). It is also at this time that a link was established between these ancient understandings of money and more modern interpretations. This happened through the teachings of Aristotle that were to have such a crucial influence on early Western thought. In Ethics, Aristotle clearly states the state/institutional theory of money, and rejects any commodity-based or trading concept of money, by saying "Money exists not by nature but by law." The Dialogues of Plato contain similar views (Jowett (1937)). This insight was reflected in many monetary systems of the time, which contrary to a popular prejudice among monetary historians were based on state-backed fiat currencies rather than commodity monies. Examples include the extremely successful Spartan system (approx. 750-415 BC), introduced by Lycurgus, which was based on iron disks of low intrinsic value, the 390-350 BC Athenian system, based on copper, and most importantly the early Roman system (approx. 700-150 BC), which was based on bronze tablets, and later coins, whose material value was far below their face value.

Many historians (Del Mar (1895)) have partly attributed the eventual collapse of the Roman republic to the emergence of a plutocracy that accumulated immense private wealth at the expense of the general citizenry. Their ascendancy was facilitated by the introduction of privately controlled silver money, and later gold money, at prices that far exceeded their earlier commodity value prices, during the emergency period of the Punic wars. With the collapse of Rome much of the ancient monetary knowledge and experience was lost in the West. But the teachings of Aristotle remained important through their influence on the scholastics, including St. Thomas Acquinas (1225-1274). This may be part of the reason why, until the Industrial Revolution, monetary control in the West remained generally either in government or religious hands, and was inseparable from ultimate sovereignty in society. However, this was to change eventually, and the beginnings can be traced to the first emergence of private banking after the fall of Byzantium in 1204, with rulers increasingly relying on loans from private bankers to finance wars. But ultimate monetary control remained in sovereign hands for several more centuries. The Bank of Amsterdam (1609-1820) in the Netherlands was still government-owned and maintained a 100\% reserve backing for deposits. And the Mixt Moneys of Ireland (1601) legal case in England confirmed the right of the sovereign to issue intrinsically worthless base metal coinage as legal tender. It was the English Free Coinage Act of 1666, which placed control of the money supply into private hands, and the founding of the privately controlled Bank of England in 1694, that first saw a major sovereign relinquishing monetary control, not only to the central bank but also to the private banking interests behind it. The following centuries would provide ample opportunities to compare the 
results of government and private control over money issuance.

The results for the United Kingdom are quite clear. Shaw (1896) examined the record of monarchs throughout English history, and found that, with one exception (Henry VIII), the king had used his monetary prerogative responsibly for the benefit of the nation, with no major financial crises. On the other hand, Del Mar (1895) finds that the Free Coinage Act inaugurated a series of commercial panics and disasters which to that time were completely unknown, and that between 1694 and 1890 twenty-five years never passed without a financial crisis in England.

The principal advocates of this system of private money issuance were Adam Smith (1776) and Jeremy Bentham (1818), whose arguments were based on a fallacious notion of commodity money. But a long line of distinguished thinkers argued in favor of a return to (or, depending on the country and the time, a maintenance of) a system of government money issuance, with the intrinsic value of the monetary metal (or material) being of no consequence. The list of their names, over the centuries, includes John Locke $(1692,1718)$, Benjamin Franklin (1729), George Berkeley (1735), Charles de Montesquieu (1748, in Montague (1952)), Thomas Paine (1796), Thomas Jefferson (1803), David Ricardo (1824), Benjamin Butler (1869), Henry George (1884), Georg Friedrich Knapp (1924), Frederick Soddy (1926, 1933, 1943), Pope Pius XI (1931) and the Archbishop of Canterbury (1942, in Dempsey (1948)).

The United States monetary experience provides similar lessons to that of the United Kingdom. Colonial paper monies issued by individual states were of the greatest economic advantage to the country (Franklin (1729)), and English suppression of such monies was one of the major reasons for the revolution (Del Mar (1895)). The Continental Currency issued during the revolutionary war was crucial for allowing the Continental Congress to finance the war effort. There was no over-issuance by the colonies, and the only reason why inflation eventually took hold was massive British counterfeiting (Franklin (1786), Schuckers (1874)). ${ }^{17}$ The government also managed the issuance of paper monies in the periods 1812-1817 and 1837-1857 conservatively and responsibly (Zarlenga (2002)). The Greenbacks issued by Lincoln during the Civil War were again a crucial tool for financing the war effort, and as documented by Randall (1937) and Studenski and Kroos (1952) their issuance was responsibly managed, resulting in comparatively less inflation than the financing of the war effort in World War I. ${ }^{18}$ Finally, the Aldrich-Vreeland system of the 1907-1913 period, where money issuance was government controlled through the Comptroller of the Currency, was also very effectively administered (Friedman and Schwartz (1963), p. 150). The one blemish on the record of government money issuance was deflationary rather than inflationary in nature. The van Buren presidency triggered the 1837 depression by insisting that the government issuance of money had a $100 \%$ gold/silver backing. This completely unnecessary straitjacket meant that the money supply was inadequate for a growing economy. As for the U.S. experience with private money issuance, the record was much worse. Private banks and the privately-owned First and especially Second Bank of the United States repeatedly triggered disastrous business cycles due to initial monetary over-expansion accompanied by high debt levels, followed by

\footnotetext{
${ }^{17}$ The assignats of the French revolution also resulted in very high inflation partly due to British counterfeiting (Dillaye (1877))

${ }^{18}$ Zarlenga (2002) documents very persistent attempts by the private banking industry, throughout the late 19th century, to have the Greenbacks withdrawn from circulation.
} 
monetary contraction and debt deflation, with bankers eventually collecting the collateral of defaulting debtors, thereby contributing to an increasing concentration of wealth. Massive losses were also caused by spurious private bank note issuance in the 1810-1820 period, and similar experiences continued throughout the century (Gouge (1833), Knox (1903)). ${ }^{19}$ The large expansion of private credit in the period leading up to the Great Depression was another example of a bank-induced boom-bust cycle, although its severity was exacerbated by mistakes of the Federal Reserve (Friedman and Schwartz (1963)). ${ }^{20}$

Finally, a brief word on a favorite example of advocates of private control over money issuance, the German hyperinflation of 1923, which was supposedly caused by excessive government money printing. The Reichsbank president at the time, Hjalmar Schacht, put the record straight on the real causes of that episode in Schacht (1967). Specifically, in May 1922 the Allies insisted on granting total private control over the Reichsbank. This private institution then allowed private banks to issue massive amounts of currency, until half the money in circulation was private bank money that the Reichsbank readily exchanged for Reichsmarks on demand. The private Reichsbank also enabled speculators to short-sell the currency, which was already under severe pressure due to the transfer problem of the reparations payments pointed out by Keynes (1929). ${ }^{21}$ It did so by granting lavish Reichsmark loans to speculators on demand, which they could exchange for foreign currency when forward sales of Reichsmarks matured. When Schacht was appointed, in late 1923, he stopped converting private monies to Reichsmark on demand, he stopped granting Reichsmark loans on demand, and furthermore he made the new Rentenmark non-convertible against foreign currencies. The result was that speculators were crushed and the hyperinflation was stopped. Further support for the currency came from the Dawes plan that significantly reduced unrealistically high reparations payments. This episode can therefore clearly not be blamed on excessive money printing by a government-run central bank, but rather on a combination of excessive reparations claims and of massive money creation by private speculators, aided and abetted by a private central bank. It should be pointed out that many more recent hyperinflations in emerging markets also took place in the presence of large transfer problems and of intense private speculation against the currency. But a detailed evaluation of the historical experiences of emerging markets is beyond the scope of the present paper.

To be fair, there have of course been historical episodes where government-issued currencies collapsed amid high inflation. But the lessons from these episodes are so obvious, and so unrelated to the fact that monetary control was exercised by the government, that they need not concern us here. These lessons are: First, do not put a convicted murderer and gambler, or similar characters, in charge of your monetary system (the 1717-1720 John Law episode in France). Second, do not start a war, and if you do, do not lose it (wars, especially lost ones, can destroy any currency, irrespective of whether monetary control is exercised by the government or by private parties).

\footnotetext{
${ }^{19}$ The widespread financial fraud committed prior to the U.S. S\&L crisis (Black (2005)) and to the Great Recession (Federal Bureau of Investigations (2007)) is the 20th- and 21st-century equivalent of fraudulent bank note issuance - of counterfeiting money.

${ }^{20}$ This interpretation of Friedman and Schwartz (1963) is not shared by all students of history. Keen (2011) argues that the main cause of the Great Depression was excessive prior credit expansion by banks.

${ }^{21}$ The transfer problem arises when a large foreign debt is denominated in foreign currency, but has to be serviced by raising revenue in domestic currency. As this leads to the domestic currency's rapid depreciation, it makes debt service harder.
} 
To summarize, the Great Depression was just the latest historical episode to suggest that privately controlled money creation has much more problematic consequences than government money creation. Many leading economists of the time were aware of this historical fact. They also clearly understood the specific problems of bank-based money creation, including the fact that high and potentially destabilizing debt levels become necessary just to create a sufficient money supply, and the fact that banks and their fickle optimism about business conditions effectively control broad monetary aggregates. ${ }^{22}$ The formulation of the Chicago Plan was the logical consequence of these insights.

\section{B. The Chicago Plan}

The Chicago Plan provides an outline for the transition from a system of privately-issued debt-based money to a system of government-issued debt-free money. The history of the Chicago Plan is explained in Phillips (1994). It was first formulated in the United Kingdom by the 1921 Nobel Prize winner in chemistry, Frederick Soddy, in Soddy (1926). Professor Frank Knight of the University of Chicago picked up the idea almost immediately, in Knight (1927). The first, March 1933 version of the plan is a memorandum to President Roosevelt (Knight (1933)). Many of Knight's distinguished University of Chicago colleagues supported the plan and signed the memorandum, including especially Henry Simons, who was the author of the second, more detailed memorandum to Roosevelt in November 1933 (Simons et al. (1933)). The Chicago economists, and later Irving Fisher of Yale, were in constant contact with the Roosevelt administration, which seriously considered their proposals, as reflected for example in the government memoranda of Gardiner Means (1933) and Lauchlin Currie (1934), and the bill of Senator Bronson Cutting (see Cutting (1934)). Fisher supported the Chicago Plan for the same reason as the Chicago economists, but he had one additional concern not shared by them, the improved ability to use monetary policy to affect debtor-creditor relations through reflation, in an environment where, in his opinion, over-indebtedness had become a major source of crises for the economy.

Several of the signers of the Chicago Plan were later to become known as the founders of the Chicago School of Economics. Though they were strong proponents of laissez-faire in industry, they did not question the right of the federal government to have an exclusive monopoly on money issuance (Phillips (1994)). ${ }^{23}$ The Chicago Plan was a strategy for establishing that monopoly. There was concern because it called for a major change in the structure of banking, but 1933 was a year of major financial crisis, and "...most of us suspect that measures at least as drastic as those described in our statement can hardly be avoided, except temporarily, in any event." (Knight (1933)). Furthermore, in Fisher (1935) we find supportive statements from bankers arguing that the conversion to $100 \%$ reserve backing would be a simple matter. Friedman (1960) expresses the same view.

Many different versions of the Chicago Plan circulated in the 1930s and beyond. All of

\footnotetext{
${ }^{22}$ This understanding is evident in statements by leading economists at the time, including Wicksell (1906), "The lending operations of the bank will consist rather in its entering in its books a fictitious deposit equal to the amount of the loan..." and Rogers (1929), "a large proportion of ... [deposits] under certain circumstances may be manufactured out of whole cloth by the banking institutions themselves."

${ }^{23}$ Furthermore, unlike today's free market economists, they argued for a strong government role in infrastructure provision and in regulation, see e.g. Simons (1948).
} 
them were very similar in their prescriptions for money, but they differed significantly in their prescriptions for credit. For money, all of them envisaged $100 \%$ reserve backing for deposits, either immediately or over time, and all of them advocated monetary rules rather than discretion. For credit, the original plan advocated the replacement of traditional banks with investment trusts that issue equity, and that in addition sell their own private non-monetary interest-bearing securities to fund lending. But Simons was always acutely aware that such securities might over time develop into near monies, thereby defeating the purpose of the Chicago Plan by turning the investment trusts into new creators of money. There are two alternatives that avoid this outcome. Simons himself, in Simons (1946), advocated a "financial good society" where all private property eventually takes the form of either government currency, government bonds, corporate stock, or real assets. The investment trusts that take over the credit function would therefore be both funded by equity and invest in corporate equity, as corporate debt disappears completely. The other alternative is for banks to issue their debt instruments to the government rather than to the private sector. This option is considered in the government versions of the plan formulated by Means (1933) and Currie (1934), and also in the academic proposal by Angell (1935). Beyond preventing the emergence of new near-monies, this alternative has three major additional advantages. First, it makes it possible to effect an immediate and full transition to the Chicago Plan even if the deposits that need to be backed by reserves are very large relative to outstanding amounts of government debt that can be used to back them. This was the main concern of Angell (1935). The reason is that when government funding is available, banks can immediately borrow any amount of required reserves from the government. Second, switching to full government funding of credit can maximize the fiscal benefits of the Chicago Plan. This gives the government budgetary space to reduce tax distortions, which stimulates the economy. Third, when investment trusts need to switch their funding from cheap deposits to more expensive privately held debt liabilities, their cost of funding, and therefore the interest rate on loans, increases relative to the rate on risk-free government debt. This will tend to reduce any economic activity that continues to depend on bank lending. When the switch is to treasury-held debt liabilities, the government is free to set a lower funding interest rate that keeps interest rates on bank loans to private agents aligned with government borrowing costs. It is for all of these reasons that we use this version of the Chicago Plan for the core of our theoretical model. Specifically, after the government buy-back of non-investment loans, the remaining credit function of banks is carried out by private institutions that fund conventional investment loans with a combination of equity and treasury credit provided at a policy-determined rate.

In our model there is no need for Simons' investment trusts, because the four different classes of private bank debtors are assumed to have identical debt levels within each class. This means that a fair debt buy-back, in the sense that the government makes equal per capita transfers to each debtor within a given group, leads to the exact cancellation of every single agent's debts. But if the same transfers were to be received by agents with highly heterogeneous debt levels, e.g. due to idiosyncratic income processes, some agents would end up with a residual debt while others would end up with a residual financial asset. In order to prevent the latter from adding to the money supply, by becoming near-monies, intermediating these assets by way of Simons' investment trusts would be the natural solution. Under the version of the Chicago Plan considered in this paper these trusts would be quantitatively less significant than originally envisaged by Simons, 
because treasury-funded banks remain at the core of the financial system. But they retain a key function by facilitating intertemporal smoothing by households and firms.

In another respect our proposal remains very close to Simons: After the large-scale debt buy-backs made possible by the government's initial seigniorage gains, bank credit to households can in net aggregate terms be completely eliminated, as can short-term working capital credit to firms. This is because credit is no longer needed to create the economy's money supply, with both households and firms replacing debt-based private money with debt-free government-issued money. The only credit that remains is lending for productive investment purposes. In terms of the composition of bank assets, our remaining banking system therefore ends up closely resembling the banking structures in pre-World-War-I/II France (advocated by the Saint-Simonians) and especially Germany. It should be remembered that prior to World War I Germany's industrial successes were widely viewed as reflecting the superior efficiency of its financial system, which was based on the notion that successful industrial development needed long-term stable financing and government support. This view was articulated in Naumann (1915), with subsequent support from both UK and U.S. economists (Foxwell (1917a,b), Veblen (1921)). Simons (1946) is essentially in the same tradition. The main reason why the more short-term-oriented Anglo-Saxon tradition of finance has come to dominate throughout the world is the victory of the United States, Britain and their allies in the two world wars.

The Chicago Plan was never adopted as law, due to strong resistance from the banking industry. But it played a major role in the passage of the 1935 Banking Act, which also faced resistance but was considered more acceptable to banks. As documented in Phillips (1994), the 1935 Act was at the time not considered the final word on banking reform, and efforts by proponents of the Chicago Plan, especially by Irving Fisher, continued for many years afterwards. The long list of academic treatments in the 1930s, almost universally sympathetic, includes Whittlesey (1935), Douglas (1935), Angell (1935), Fisher (1936) and Graham (1936). Advocacy for the Chicago Plan continued after the war, with Allais (1947), Friedman (1960), who was a lifelong supporter, and Tobin (1985). The "narrow banking" literature is in the same tradition, but with a narrower focus on the safety of the deposit part of banks' business. See Phillips (1994) for references.

Friedman's work is especially important. In Friedman (1967) he explains that his support for the Chicago Plan is partly based on different arguments from those of Simons and Fisher. Simons's and Fisher's main concern was the instability of bank credit in a world where that credit determines the money supply. They therefore advocated more governmental control over the money creation process via more control over bank lending. Friedman was interested in precisely the opposite, his concern was with making the government commit to fixed rules in order to otherwise keep it from interfering with borrowing and lending relationships. This would become possible because under the Chicago Plan a fixed money growth rule would give the policymaker much more control over actual monetary aggregates than under the current monetary system. Simons and Fisher also advocated a fixed money growth rule, so in this respect the Chicago Plan would satisfy both sides. But the degree to which it otherwise approximates the ideals of these thinkers depends on details of the implementation on the credit side. Our proposed implementation is closer to Simons and Fisher than to Friedman, by mostly eliminating private debt funding (but not equity funding) of banks' residual lending business, because of the multiple above-mentioned advantages of this approach. 


\section{The Model under the Current Monetary System}

The model economy consists of two household sectors, a productive sector, a banking sector and a government. It features a number of nominal and real rigidities. A comprehensive model, with multiple sectors and multiple rigidities, has three major advantages for the task we set ourselves in this paper. First, it provides an integrated framework where all of the critical differences between the Chicago Plan and current monetary arrangements emerge simultaneously. Second, it generates an empirically realistic scenario of the transition to the Chicago Plan, based on an accurate (as far as possible) estimate of the balance sheet sizes of different types of bank borrowers. Third, it makes our model consistent with the findings of the empirical DSGE literature, which has identified a number of nominal and real rigidities that are critical for the ability of such models to generate reasonable impulse responses.

Four types of private agents interact directly with banks. Financially unconstrained households have large financially unencumbered investments that include not only bank deposits but also land and government debt. Financially constrained households own bank deposits and land that serve as collateral for consumer loans and mortgages.

Manufacturers own bank deposits that serve as collateral for working capital loans. Capital investment funds own physical capital that serves as collateral for investment loans. Other sectors include capital goods producers, who produce the economy's capital stock subject to investment adjustment costs, and unions, who supply labor subject to nominal rigidities in wage setting.

The economy experiences a constant positive technology growth rate $g=T_{t} / T_{t-1}$, where $T_{t}$ is the level of labor augmenting technology. When the model's nominal variables, say $X_{t}$, are expressed in real normalized terms, we divide by the price level $P_{t}$ and the level of technology $T_{t}$. We use the notation $\check{x}_{t}=X_{t} /\left(T_{t} P_{t}\right)=x_{t} / T_{t}$, with the steady state of $\check{x}_{t}$ denoted by $\bar{x}$. The population shares of unconstrained and constrained households are given by $\omega$ and $1-\omega$.

Our exposition of each agent's optimization problem is kept brief in the interest of space. A complete derivation is contained in the Technical Appendix. Because of their central role in the economy, we start our exposition with banks.

\section{A. Banks}

Banks lend to constrained households by way of consumer loans secured on bank deposits (superscript $c$ ) and of mortgages secured on land (superscript $a$ ), to manufacturers by way of working capital loans secured on bank deposits (superscript $m$ ), to capital investment funds by way of investment loans secured on fixed capital (superscript $k$ ), and to the government by way of holdings of part of the outstanding stock of government bonds.

Banks maintain deposits for unconstrained households (superscript $u$ ), constrained households and manufacturers. Bank deposits are modelled as a single asset type with a one-period maturity. We emphasize that in our calibration this will correspond to all bank liabilities, and therefore includes not just demand deposits but also all other near-monies. 
This will allow our model to address the concerns with near-monies stressed by Simons (1946, 1948), Angell (1935) and Allais (1947).

Apart from deposits, banks' own net worth is another important source of funds. The reason why banks maintain positive net worth is that the government imposes official minimum capital adequacy requirements (henceforth referred to as MCAR), to neutralize the moral hazard created by the fact that banks operate under limited liability. These regulations are modeled to closely resemble the current Basel regime, by requiring banks to pay penalties if they violate the MCAR. ${ }^{24}$ Banks' total equity exceeds the minimum requirements in equilibrium, in order to provide a buffer against adverse shocks that could cause equity to drop below the MCAR and trigger penalties.

Moral hazard creates an incentive for banks to not protect themselves against negative shocks to profits that are larger than their existing equity base. In the absence of regulation, banks therefore have an incentive to take on large amounts of lending risk and to minimize their own equity base. As this would mean that depositors would be exposed to significant risks of capital losses, one solution is for deposit contracts to reflect that risk, and to thereby discipline bankers. But this solution is impractical, as it requires depositors to engage in costly monitoring, and also because it may leave the financial system prone to bank runs. The preferred policy solution has therefore generally been some form of deposit insurance that obviates the need for complicated deposit contracts, and that minimizes the probability of bank runs. But in that case, given that deposit insurance schemes are generally not sufficiently funded to insure against systemic crises, the risks of large capital losses accrue to taxpayers rather than depositors. Deposit insurance therefore has to be accompanied by direct capital adequacy regulations that penalize banks for maintaining an insufficient equity buffer, and thereby exposing taxpayers to the risk of capital losses. That is the environment assumed in this paper, and the calibration of these regulations will be such that the probability of banks becoming insolvent and having to call on deposit insurance is vanishingly small.

Banks are assumed to face heterogeneous realizations of credit risks, and are therefore indexed by $j$. We sometimes use the general notation $x \in\{c, a, m, k, u\}$ to represent the different groups of agents with which banks interact. Banks' nominal and real normalized loan stocks between periods $t$ and $t+1$ are given by $L_{t}^{x}(j)$ and $\check{\ell}_{t}^{x}(j)$, while their deposit stocks are $D_{t}^{x}(j)$ and $\check{d}_{t}^{x}(j)$, holdings of government bonds are $B_{t}^{b}(j)$ and $\check{b}_{t}^{b}(j)$, and net worth is $N_{t}^{b}(j)$ and $\check{n}_{t}^{b}(j)$. Banks' nominal and ex-post real deposit rates are given by $i_{d, t}$ and $r_{d, t}$, where $r_{d, t}=i_{d, t-1} / \pi_{t}$, and where $\pi_{t}=P_{t} / P_{t-1}$. Their wholesale cost of funding loans is given by $i_{\ell, t}$ and $r_{\ell, t}$ for all loans except mortgage loans, and by $i_{\ell, t}^{h}$ and $r_{\ell, t}^{h}$ for mortgage loans. Banks' retail nominal and real lending rates, which add a credit risk spread to the wholesale rates, are given by $i_{r, t}^{x}$ and $r_{r, t}^{x}$. Finally, nominal and real interest rates on government debt are denoted by $i_{t}$ and $r_{t}$. Bank $j$ 's balance sheet in real normalized terms is given by

$$
(1-\omega)\left(\check{\ell}_{t}^{c}(j)+\check{\ell}_{t}^{a}(j)\right)+\check{\ell}_{t}^{m}(j)+\check{\ell}_{t}^{k}(j)+\check{b}_{t}^{b}(j)=\omega \check{d}_{t}^{u}(j)+(1-\omega) \check{d}_{t}^{c}(j)+\check{d}_{t}^{m}(j)+\check{n}_{t}^{b}(j),
$$

where for future reference we define $\check{\ell}_{t}(j)=(1-\omega) \check{\ell}_{t}^{c}(j)+\check{\ell}_{t}^{m}(j)+\check{\ell}_{t}^{k}(j)$, $\check{\ell}_{t}^{h}(j)=(1-\omega) \check{\ell}_{t}^{a}(j), \check{\ell}_{t}^{\ell}(j)=\check{\ell}_{t}(j)+\check{\ell}_{t}^{h}(j)$, and $\check{d}_{t}(j)=\omega \check{d}_{t}^{u}(j)+(1-\omega) \check{d}_{t}^{c}(j)+\check{d}_{t}^{m}(j)$.

\footnotetext{
${ }^{24}$ Furfine (2001) and van den Heuvel (2005) contain a list of such penalties, according to the Basel rules or to national legislation, such as the U.S. Federal Deposit Insurance Corporation Improvement Act of 1991.
} 
Banks can make losses on each of their four loan categories, which are given by $\check{\Lambda}_{t}^{b}(j)=(1-\omega)\left(\check{\Lambda}_{t}^{c}(j)+\check{\Lambda}_{t}^{a}(j)\right)+\check{\Lambda}_{t}^{m}(j)+\check{\Lambda}_{t}^{k}(j)$. The stock of government bonds on banks' balance sheets is assumed to equal a fixed share of the total balance sheet, $\check{b}_{t}^{b}(j)=s_{b}\left(\check{d}_{t}(j)+\check{n}_{t}^{b}(j)\right)$. This cash constraint specification is based on the fact that banks, on a daily basis, require government bonds as collateral in order to be able to make payments to other financial market participants. This is therefore a financial markets equivalent to the usual goods market rationale for cash constraints. We assume a cash constraint rather than a cash-in-advance constraint because this simplifies the analysis without losing any important insights.

Our model focuses on bank solvency considerations and ignores liquidity management problems. Banks are therefore modeled as having no incentive, either regulatory or precautionary, to maintain cash reserves at the central bank. Because, furthermore, for households cash is dominated in return by bank deposits, in this economy there is no demand for government-provided real cash balances. Empirically, as discussed in the introduction, such balances are vanishingly small relative to the size of bank deposits.

Banks are assumed to face pecuniary costs of falling short of official minimum capital adequacy ratios. The regulatory framework we assume introduces a discontinuity in outcomes for banks. In any given period, a bank either remains sufficiently well capitalized, or it falls short of capital requirements and must pay a penalty. In the latter case, bank net worth suddenly drops further. The cost of such an event, weighted by the appropriate probability, is incorporated into the bank's optimal capital choice. Modeling this regulatory framework under the assumption of homogenous banks would lead to outcomes where all banks simultaneously either pay or do not pay the penalty. A more realistic specification therefore requires a continuum of banks, each of which is exposed to idiosyncratic shocks, so that there is a continuum of ex-post capital adequacy ratios across banks, and a time-varying small fraction of banks that have to pay penalties in each period.

Specifically, banks are assumed to be heterogeneous in that the return on their loan book is subject to an idiosyncratic shock $\omega_{t+1}^{b}$ that is lognormally distributed, with $E\left(\omega_{t+1}^{b}\right)=1$ and $\operatorname{Var}\left(\ln \left(\omega_{t+1}^{b}\right)\right)=\left(\sigma_{t+1}^{b}\right)^{2}$ and with the density function and cumulative density function of $\omega_{t+1}^{b}$ denoted by $f_{t}^{b}\left(\omega_{t+1}^{b}\right)$ and $F_{t}^{b}\left(\omega_{t+1}^{b}\right)$. This can reflect a number of individual bank characteristics, such as differing loan recovery rates, and differing success at raising non-interest income and minimizing non-interest expenses, where the sum of the last two categories would have to sum to zero over all banks.

The regulatory framework stipulates that banks have to pay a real penalty of $\chi\left(\check{\ell}_{t}^{\ell}(j)+\breve{b}_{t}^{b}(j)\right)$ at time $t+1$ if the sum of the gross returns on their loan book, net of gross deposit interest expenses and loan losses, is less than a fraction $\gamma_{t}$ of the gross risk-weighted returns on their loan book. Different risk-weights will be one of the critical determinants of equilibrium interest rate spreads. We assume that the risk-weight on all non-mortgage loans is $100 \%$, the risk-weight on mortgage loans is $\zeta$, and the risk weight on government debt is zero. Then the penalty cutoff condition is given by

$$
\begin{gathered}
\left(r_{\ell, t+1} \check{\ell}_{t}(j)+r_{\ell, t+1}^{h} \check{\ell}_{t}^{h}(j)+r_{t+1} \check{b}_{t}^{b}(j)\right) \omega_{t+1}^{b}-r_{d, t+1} \check{d}_{t}(j)-\check{\Lambda}_{t+1}^{b}(j) \\
<\gamma_{t}\left(r_{\ell, t+1} \check{\ell}_{t}(j)+\zeta r_{\ell, t+1}^{h} \check{\ell}_{t}^{h}(j)\right) \omega_{t+1}^{b} .
\end{gathered}
$$


Because the left-hand side equals pre-dividend (and pre-penalty) net worth in $t+1$, while the term multiplying $\gamma_{t}$ equals the value of risk-weighted assets in $t+1, \gamma_{t}$ represents the minimum capital adequacy ratio of the Basel regulatory framework. We denote the cutoff idiosyncratic shock to loan returns below which the MCAR is breached by $\bar{\omega}_{t}^{b}$. It is given by

$$
\bar{\omega}_{t}^{b} \equiv \frac{r_{d, t} \check{d}_{t-1}+x \check{\Lambda}_{t}^{b}}{\left(1-\gamma_{t-1}\right) r_{\ell, t} \check{\ell}_{t-1}+\left(1-\gamma_{t-1} \zeta\right) r_{\ell, t}^{h} \check{\ell}_{t-1}^{h}+r_{t} \check{b}_{t-1}^{b}} .
$$

Banks choose their loan volumes to maximize their pre-dividend net worth, which equals the sum of gross returns on the loan book minus gross interest charges on deposits, loan losses, and penalties:

$$
\begin{gathered}
\underset{\check{\ell}_{t}(j), \check{\ell}_{t}^{h}(j)}{\operatorname{Max}} E_{t}\left[\left(r_{\ell, t+1} \check{\ell}_{t}(j)+r_{\ell, t+1}^{h} \check{\ell}_{t}^{h}(j)+r_{t+1} \check{b}_{t}^{b}(j)\right) \omega_{t+1}^{b}-r_{d, t+1} \check{d}_{t}(j)\right. \\
\left.-\check{\Lambda}_{t+1}^{b}(j)-\chi\left(\check{\ell}_{t}(j)+\check{\ell}_{t}^{h}(j)+\check{b}_{t}^{b}(j)\right) F_{t}^{b}\left(\bar{\omega}_{t+1}^{b}\right)\right] .
\end{gathered}
$$

The optimality conditions are shown in full in the Technical Appendix. ${ }^{25}$ They state that banks' wholesale lending rates $i_{\ell, t}$ and $i_{\ell, t}^{h}$ are at a premium over their deposit rate $i_{d, t}$ by magnitudes that depend on the size of the MCAR $\gamma_{t}$, the penalty coefficient $\chi$ for breaching the MCAR, and expressions $F_{t}^{b}\left(\bar{\omega}_{t+1}^{b}\right)$ and $f_{t}^{b}\left(\bar{\omega}_{t+1}^{b}\right)$ that reflect the expected riskiness of banks $\sigma_{t+1}^{b}$ and therefore the likelihood of a breach. Banks' retail rates $i_{r, t}^{x}$ on the other hand, whose determination is discussed in the next subsection, are at another premium over $i_{\ell, t}$ and $i_{\ell, t}^{h}$, to compensate for the bankruptcy risks of the four different borrower types. A sensible interpretation of the wholesale rate is therefore as the rate a bank would charge to a hypothetical borrower (not present in the model) with zero default risk. Note that the policy rate $i_{t}$ does not enter these optimality conditions as the marginal cost of funds, because the marginal cost of funds is given by the rate at which banks can create their own funds, which is $i_{d, t}$.

Another outcome of this optimization problem is banks' actually maintained Basel capital adequacy ratio $\gamma_{t}^{a}$. This will be considerably above the minimum requirement $\gamma_{t}$, because by maintaining an optimally chosen buffer banks protect themselves against the risk of penalties while minimizing the cost of excess capital. There is no simple formula for $\gamma_{t}^{a}$, which in general depends nonlinearly on a number of parameters. We will however calibrate its steady state value below, for which we use the notation $\bar{\gamma}^{a}$.

Given the linearity of banks' technology, balance sheet items can be easily aggregated over all banks, and we can therefore drop bank-specific indices. Banks' aggregate net worth $\check{n}_{t}^{b}$ represents an additional state variable of the model, and is given by the gross return on loans, minus the sum of gross interest on deposits, loan losses, penalties incurred, and dividends. The cost of penalties, which is partly a lump-sum transfer to households and partly a real resource cost, is $\check{\mathcal{M}}_{t}^{b}=\frac{\chi}{x}\left(\check{\ell}_{t-1}+\check{\ell}_{t-1}^{h}+\check{b}_{t-1}^{b}\right) F_{t}^{b}\left(\bar{\omega}_{t}^{b}\right)$. Dividends, which will be discussed in more detail below, are given by $\delta^{b} \check{n}_{t}^{b}$. Then we have

$$
\check{n}_{t}^{b}=\frac{1}{x}\left(r_{\ell, t} \check{\ell}_{t-1}+r_{\ell, t}^{h} \check{\ell}_{t-1}^{h}+r_{t} \check{b}_{t-1}^{b}-r_{d, t} \check{d}_{t-1}\right)-\check{\Lambda}_{t}^{b}-\check{\mathcal{M}}_{t}^{b}-\delta^{b} \check{n}_{t}^{b}
$$

\footnotetext{
${ }^{25}$ While the optimality conditions are shown in terms of expected real interest rates, which are subject to uncertainty in inflation, our discussion is in terms of the unconditional (except for default) nominal interest rates actually set by banks. Our course inflation affects all real rates in the same fashion.
} 


\section{B. Lending Technologies}

Almost identical forms of the borrowing problem are solved by constrained households (for consumer and mortgage loans), manufacturers and capital investment funds. In this subsection we again use general notation, with $x \in\{c, a, m, k\}$ representing the four different types of loans. Borrowers use an optimally chosen combination of nominal/real bank loans $L_{t}^{x}(j) / \ell_{t}^{x}(j)$ and internal funds to purchase nominal/real assets $X_{t} / x_{t}$. The ex-post nominal/real returns on the latter are denoted by $\operatorname{Ret}_{x, t}$ and ret $_{x, t}$.

After the asset purchase each borrower of type $x$ draws an idiosyncratic shock which changes $x_{t}(j)$ to $\omega_{t+1}^{x} x_{t}(j)$ at the beginning of period $t+1$, where $\omega_{t+1}^{x}$ is a unit mean lognormal random variable distributed independently over time and across borrowers of type $x$. The standard deviation of $\ln \left(\omega_{t+1}^{x}\right), S_{t+1}^{z} \sigma_{t+1}^{x}$, is itself a stochastic process that will play a key role in our analysis. We will refer to this as the borrower riskiness shock. It has an aggregate component $S_{t+1}^{z}$ that is common across borrower types, and a type-specific component $\sigma_{t+1}^{x}$. The density function and cumulative density function of $\omega_{t+1}^{x}$ are given by $f_{t}^{x}\left(\omega_{t+1}^{x}\right)$ and $F_{t}^{x}\left(\omega_{t+1}^{x}\right)$.

We assume that each borrower receives a standard debt contract from the bank. This specifies a nominal loan amount $L_{t}^{x}(j)$ and a gross nominal retail rate of interest $i_{r, t}^{x}$ to be paid if $\omega_{t+1}^{x}$ is sufficiently high to rule out default. The critical difference between our model and those of Bernanke et al. (1999) and Christiano et al. (2011) is that the interest rate $i_{r, t}^{x}$ is assumed to be pre-committed in period $t$, rather than being determined in period $t+1$ after the realization of time $t+1$ aggregate shocks. The latter, conventional assumption ensures zero ex-post profits for banks at all times, while under our debt contract banks make zero expected profits, but realized ex-post profits generally differ from zero. Borrowers who draw $\omega_{t+1}^{x}$ below a cutoff level $\bar{\omega}_{t+1}^{x}$ cannot pay this interest rate and go bankrupt. They must hand over all their assets to the bank, but the bank can only recover a fraction $\left(1-\xi^{x}\right)$ of the asset value of such borrowers. The remaining fraction represents monitoring costs, which are assumed to be partially paid out to households in a lump-sum fashion, with the remainder representing a real resource cost. Banks' ex-ante zero profit condition for borrower group $x$, in real terms, is given by

$E_{t}\left\{r_{\ell, t+1} \check{\ell}_{t}^{x}(j)-\left[\left(1-F_{t}^{x}\left(\bar{\omega}_{t+1}^{x}\right)\right) r_{r, t+1}^{x} \check{\ell}_{t}^{x}(j)+\left(1-\xi^{x}\right) \int_{0}^{\bar{\omega}_{t+1}^{x}} x_{t}(j) r e t_{x, t+1} \omega^{x} f_{t}^{x}\left(\omega^{x}\right) d \omega^{x}\right]\right\}=0$.

This states that the payoff to lending must equal wholesale interest charges $r_{\ell, t+1} \check{\ell}_{t}^{x}(j) .{ }^{26}$ The first term in square brackets is the gross real interest income on loans to borrowers whose idiosyncratic shock exceeds the cutoff level, $\omega_{t+1}^{x} \geq \bar{\omega}_{t+1}^{x}$. The second term is the amount collected by the bank in case of the borrower's bankruptcy, where $\omega_{t+1}^{x}<\bar{\omega}_{t+1}^{x}$. This cash flow is based on the return $\operatorname{ret}_{x, t+1} \omega$ on the asset $x_{t}(j)$, but multiplied by the factor $\left(1-\xi^{x}\right)$ to reflect a proportional bankruptcy cost $\xi^{x}$. The ex-post cutoff productivity level is determined by equating, at $\omega_{t}^{x}=\bar{\omega}_{t}^{x}$, the gross interest charges due in the event of continuing operations $r_{r, t}^{x} \check{\ell}_{t-1}^{x}(j)$ to the gross idiosyncratic return on the borrower's asset $\operatorname{ret}_{x, t} x_{t-1}(j) \bar{\omega}_{t}^{x}$. Using this equation, we can replace the previous equation by the zero-profit condition

$$
E_{t}\left\{r_{\ell, t+1} \check{\ell}_{t}^{x}-\check{x}_{t} r e t_{x, t+1}\left(\Gamma_{x, t+1}-\xi^{x} G_{x, t+1}\right)\right\}=0
$$

\footnotetext{
${ }^{26}$ For mortgage loans, due to a lower Basel risk-weighting, the wholesale interest rate $r_{\ell, t+1}^{h}$ is lower than $r_{\ell, t+1}$.
} 
where $\Gamma_{x, t+1}$ is the bank's gross share in the earnings of the underlying asset

$$
\Gamma_{x, t+1}=\int_{0}^{\bar{\omega}_{t+1}^{x}} \omega_{t+1}^{x} f_{t}^{x}\left(\omega_{t+1}^{x}\right) d \omega_{t+1}^{x}+\bar{\omega}_{t+1}^{x} \int_{\bar{\omega}_{t+1}^{x}}^{\infty} f_{t}^{x}\left(\omega_{t+1}^{x}\right) d \omega_{t+1}^{x},
$$

and $\xi^{x} G_{x, t+1}$ is the proportion of earnings of the asset that the lender has to spend on monitoring costs

$$
\xi^{x} G_{x, t+1}=\xi^{x} \int_{0}^{\bar{\omega}_{t+1}^{x}} \omega_{t+1}^{x} f_{t}^{x}\left(\omega_{t+1}^{x}\right) d \omega_{t+1}^{x} .
$$

In other words, the bank will set the terms of the lending contract, in particular the unconditional nominal lending rate $i_{r, t}^{x}$, such that its expected gross share in the earnings of the underlying assets is sufficient to cover monitoring costs and the opportunity cost of the loan. The borrower is left with a share $1-\Gamma_{x, t+1}$ of the asset's earnings.

The remainder of the analysis is very similar to Bernanke et al. (1999). Specifically, the borrower selects the optimal level of investment in the respective assets by maximizing $E_{t}\left\{\left(1-\Gamma_{x, t+1}\right) \check{x}_{t} r e t_{x, t+1}\right\}$ subject to (5). Borrower-specific indices can in each case be dropped because the problems are linear in balance sheet quantities. For the case of capital investment funds, whose owners will be referred to as entrepreneurs, the condition for the optimal loan contract is identical to Bernanke et al. (1999),

$$
E_{t}\left\{\left(1-\Gamma_{k, t+1}\right) \frac{r e t_{k, t+1}}{r_{\ell, t+1}}+\tilde{\lambda}_{t+1}^{k}\left[\frac{r e t_{k, t+1}}{r_{\ell, t+1}}\left(\Gamma_{k, t+1}-\xi^{k} G_{k, t+1}\right)-1\right]\right\}=0
$$

with $\tilde{\lambda}_{t+1}^{k}=\Gamma_{k, t+1}^{\omega} /\left(\Gamma_{k, t+1}^{\omega}-\xi^{k} G_{k, t+1}^{\omega}\right)$, and where $\Gamma_{k, t+1}^{\omega}$ and $G_{k, t+1}^{\omega}$ are the derivatives of $\Gamma_{k, t+1}$ and $G_{k, t+1}$ with respect to $\bar{\omega}_{t+1}^{k}$.

For the remaining three types of loan contract there are some small differences to (6). First, the nature of the asset is different. For capital investment funds the value of the asset equals $x_{t}=q_{t} k_{t}$, where $k_{t}$ is the real capital stock and $q_{t}$ is the shadow value of installed capital (Tobin's q). For mortgages this is replaced by the value of constrained households' land $p_{t}^{a} a_{t}^{c}$, where $a_{t}^{c}$ is holdings of land and $p_{t}^{a}$ is the price of land. For consumer loans and working capital loans it is replaced by the value of deposit balances $d_{t}^{c}$ and $d_{t}^{m}$. Second, for these last two cases deposit balances enter a transactions cost technology, so that in the conditions for the optimal loan contracts of those two agents there will be additional terms due to monetary wedges. Similarly, land enters the utility function of constrained households, which means that the condition for the optimal mortgage loan contract contains an additional utility-related term.

The net worth evolution of each borrower group is affected by banks' net loan losses. These are positive if wholesale interest expenses, which are the opportunity cost of banks' retail lending, exceed banks' net (of monitoring costs) share in borrowers' gross earnings on their assets. This will be the case if a larger than anticipated number of borrowers defaults, so that, ex-post, banks find that they have set their pre-committed retail lending rate at an insufficient level to compensate for lending losses. Of course, if losses are positive for banks, this corresponds to a gain for their borrowers.

Finally, according to Fisher (1936) banks' optimism about business conditions is a key driver of business cycle volatility. We evaluate this claim by studying, in both the current 
monetary environment and under the Chicago Plan, a standardized shock $S_{t}^{z}$ that multiplies each standard deviation of borrower riskiness, $\sigma_{t}^{x}, x \in\{c, a, m, k\}$. Similar to Christiano et al. (2011) and Christiano et al. (2010), this shock captures the notion of a generalized change in banks' perception of borrower riskiness. We assume that it consists of two components, $S_{t}^{z}=S_{t}^{z 1} S_{t}^{z 2}$. We specify the first component as consisting of the sum of news shocks $\varepsilon_{t}^{\text {news }}$ received over the current and the preceding 12 quarters, $\ln S_{t}^{z 1}=\Sigma_{j=0}^{12} \varepsilon_{t-j}^{\text {news }}$, while the second component is autoregressive and given by $\ln S_{t}^{z 2}=\rho_{z} \ln S_{t-1}^{z 2}+\varepsilon_{t}^{z 2}$.

\section{Transactions Cost Technologies}

Unconstrained households, constrained households and manufacturers (with superscripts $x \in\{u, c, m\}$ ), require bank deposits for transactions purposes. Our specification of the transactions cost technologies follows Schmitt-Grohé and Uribe (2004), with a nonnegative transactions cost term $s_{t}^{x}$ that is increasing in velocity $v_{t}^{x}$, or in other words decreasing in the amount of deposits held by the respective agent,

$$
s_{t}^{x}=A_{x} v_{t}^{x}+\frac{B_{x}}{v_{t}^{x}}-2 \sqrt{A_{x} B_{x}} .
$$

The velocity term $v_{t}^{x}$ is different for different agents. For households, total consumption expenditures equal $c_{t}^{x}\left(1+\tau_{c, t}\right)\left(1+s_{t}^{x}\right)$, where $c_{t}^{x}$ is the consumption level, $\tau_{c, t}$ is the consumption tax rate, and velocity is given by

$$
v_{t}^{x}=\frac{c_{t}^{x}\left(1+\tau_{c, t}\right)}{d_{t}^{x}}
$$

For manufacturers, total expenditures on inputs equal $\left(w_{t} h_{t}+r_{k, t} k_{t-1}\right)\left(1+s_{t}^{m}\right)$, where $w_{t}$ is the real wage, $h_{t}$ is aggregate hours, $r_{k, t}$ is the return to capital, and velocity $v_{t}^{m}$ is given by

$$
v_{t}^{m}=\frac{w_{t} h_{t}+r_{k, t} k_{t-1}}{d_{t}^{m}}
$$

\section{Equity Ownership and Dividends}

In our model the acquisition of fresh capital by banks, manufacturers and entrepreneurs is subject to market imperfections. This is a necessary condition for capital adequacy regulations to have non-trivial effects on banks, and for external finance premia to arise in the interactions between banks and their borrowers. We use the "extended family" approach of Gertler and Karadi (2010), whereby bankers, manufacturers and entrepreneurs transfer part of their accumulated equity positions to the household budget constraint at an exogenously fixed rate.

Each unconstrained and constrained household represents an extended family that consists of four types of members, workers, manufacturers, entrepreneurs and bankers. Manufacturers, entrepreneurs and bankers enter their occupations for random lengths of time, after which they revert to being workers. There is perfect consumption insurance 
within each household. Workers supply labor, and their wages are returned to the household each period. Each manufacturer (entrepreneur, banker) manages a firm (capital investment fund, bank) and transfers earnings back to the household at the time when his period as a manufacturer (entrepreneur, banker) ends. Before that time he retains accumulated earnings within the firm (capital investment fund, bank). This means that while the household ultimately owns firms (capital investment funds, banks), equity cannot be freely injected into or withdrawn from these entities. That in turn means that equity and leverage matter for the decisions of firms (capital investment funds, banks).

Specifically, at a given point in time a fraction $(1-\mathfrak{f})$ of the representative household's members are workers, a fraction $\mathfrak{f}(1-\mathfrak{b}) \mathfrak{m}$ are manufacturers, a fraction $\mathfrak{f}(1-\mathfrak{b})(1-\mathfrak{m})$ are entrepreneurs, and a fraction $\mathfrak{f} \mathfrak{b}$ are bankers. Manufacturers (entrepreneurs, bankers) stay in their occupations for one further period with unconditional probability $p^{m}\left(p^{k}, p^{b}\right)$. This means that in each period $\left(1-p^{m}\right) \mathfrak{f}(1-\mathfrak{b}) \mathfrak{m}$ manufacturers, $\left(1-p^{k}\right) \mathfrak{f}(1-\mathfrak{b})(1-\mathfrak{m})$ entrepreneurs, and $\left(1-p^{b}\right) \mathfrak{f} \mathfrak{b}$ bankers, exit to become workers, and the same number of workers is assumed to randomly become manufacturers (entrepreneurs, bankers). The shares of workers, manufacturers, entrepreneurs and bankers within the representative household therefore remain constant over time. Distribution of net worth by manufacturers (entrepreneurs, bankers), at the time they revert to being workers, ensures that the aggregate net worth of the corporate and banking sectors does not grow to the point where debt financing (deposit financing in the case of banks) becomes unnecessary. Finally, the representative household supplies startup funds to its new manufacturers (entrepreneurs, bankers), and we assume that these represent small fractions $\iota^{m}\left(\iota^{k}, \iota^{b}\right)$ of the existing stocks of aggregate net worth in these three sectors. Each existing manufacturer (entrepreneur, banker) makes identical decisions that are proportional to his existing stock of accumulated earnings, so that aggregate decision rules for these three sectors are straightforward to derive. Therefore, the parameters that matter for aggregate dynamics are the shares of aggregate firm net worth $n_{t}^{m}$, capital investment fund net worth $n_{t}^{k}$, and banking sector net worth $n_{t}^{b}$ paid out to households each period, $\left(1-p^{m}\right) \mathfrak{f}(1-\mathfrak{b}) \mathfrak{m} n_{t}^{m},\left(1-p^{k}\right) \mathfrak{f}(1-\mathfrak{b})(1-\mathfrak{m}) n_{t}^{k}$, and $\left(1-p^{b}\right) \mathfrak{f} \mathfrak{b} n_{t}^{b}$, net of startup funds $\iota^{m} n_{t}^{m}, \iota^{k} n_{t}^{k}$ and $\iota^{b} n_{t}^{b}$. As all of these terms are proportional to the aggregate stocks of net worth, their net effects can be denoted by $\delta^{m} n_{t}^{m}, \delta^{k} n_{t}^{k}$ and $\delta^{b} n_{t}^{b}$, and our calibration is therefore simply in terms of $\delta^{m}, \delta^{k}$ and $\delta^{b}$. These parameters can alternatively be thought of as fixed dividend policies of the firm, capital investment fund and banking sectors, and for simplicity we will utilize this terminology in the remainder of the paper.

\section{E. Unconstrained Households}

The utility of a financially unconstrained household, indexed by $i$, at time $t$ depends on an external consumption habit $c_{t}^{u}(i)-\nu c_{t-1}^{u}$, where $c_{t}^{u}(i)$ is individual per capita consumption and $c_{t}^{u}$ is aggregate per capita consumption, and where consumption is a CES aggregate over goods varieties supplied by manufacturers, with elasticity of substitution $\theta$. Utility also depends on labor hours, $h_{t}^{u}(i)$, and on the real quantity of land held, $a_{t}^{u}(i)$. Lifetime expected utility at time 0 of an individual household is given by

$$
\operatorname{Max} E_{0} \sum_{t=0}^{\infty} \beta_{u}^{t}\left\{\left(1-\frac{v}{x}\right) \log \left(c_{t}^{u}(i)-\nu c_{t-1}^{u}\right)-\psi \frac{h_{t}^{u}(i)^{1+\frac{1}{\eta}}}{1+\frac{1}{\eta}}+\kappa \log \left(a_{t}^{u}(i)\right)\right\},
$$


where $\beta_{u}$ is the discount factor, $v$ indexes the degree of habit persistence, $\eta$ is the labor supply elasticity, and $\psi$ and $\kappa$ fix the utility weights of labor and land. All unconstrained households have identical initial endowments and behave identically. The household index $i$ is therefore only required for the distinction between $c_{t}(i)$ and $c_{t-1}$, and can henceforth be dropped.

The assets held by unconstrained households include land $a_{t}^{u}$, whose real normalized price is given by $\check{p}_{t}^{a}$, real domestic government debt $\check{b}_{t}^{u}$, and real bank deposits $\check{d}_{t}^{u}$. The time subscript $t$ denotes financial claims held from period $t$ to period $t+1$. The recent empirical literature has found that equilibrium real interest rates exhibit a small but positive elasticity with respect to the level of government debt (see section V). The model replicates this feature by assuming that the acquisition of financial assets requires a small transactions cost $\left(\check{b}_{t}^{u}+\breve{d}_{t}^{u}\right) \phi_{b}\left(b_{t}^{r a t}-\bar{b}^{r a t}\right)$, where $b_{t}^{r a t}=\check{b}_{t}^{g} /\left(4 g \check{d} p_{t}\right)$ is the government debt-to-GDP ratio, and $\bar{b}^{r a t}$ is its initial steady state value. ${ }^{27}$ This cost is taken as exogenous by unconstrained households, and is redistributed back to them by way of a lump-sum transfer $\check{\Psi}_{t}^{u}$.

Unconstrained households receive after-tax labor income $\check{w}_{t}^{h} h_{t}^{u}\left(1-\tau_{L, t}\right)$, where $\check{w}_{t}^{h}$ is the real wage received from unions and $\tau_{L, t}$ is the proportional labor income tax rate, and they pay net lump-sum taxes $\check{\tau}_{t}^{\mathrm{u} u}$ to the government. They also receive, in a lump-sum fashion, the profits and investment adjustment costs of the capital goods producing sector, $\check{\Pi}_{t}^{k}+\check{\mathfrak{C}}_{I, t}$, price adjustment costs $\check{\mathfrak{C}}_{P, t}$, and a share $(1-\iota) / \omega$ of other income $\check{o}_{t}$. The latter includes total dividends distributed by manufacturers, entrepreneurs and banks, plus a portion of overall monitoring costs $\check{\mathcal{M}}_{t}$ and transactions costs $\check{\mathcal{T}}_{t}$. The remaining portion of $\check{\mathcal{M}}_{t}$ and $\check{\mathcal{T}}_{t}$ is a real cost that enters the aggregate resource constraint. Monitoring costs arise in connection with the bankruptcy monitoring of bank borrowers, and also with the capital adequacy penalties of the banking sector itself, while transactions costs arise due to the monetary wedges $s_{t}^{x}$ mentioned above.

We have the overall budget constraint

$$
\begin{aligned}
& \left(\check{b}_{t}^{u}+\check{d}_{t}^{u}\right)\left(1+\phi_{b}\left(b_{t}^{r a t}-\bar{b}^{r a t}\right)\right)+\check{p}_{t}^{a} a_{t}^{u} \\
= & \frac{r_{t}}{x} \check{b}_{t-1}^{u}+\frac{r_{d, t}}{x} \check{d}_{t-1}^{u}+\check{p}_{t}^{a} a_{t-1}^{u}+\check{\Psi}_{t}^{u} \\
& -\check{c}_{t}^{u}\left(1+s_{t}^{u}\right)\left(1+\tau_{c, t}\right)-\check{\tau}_{t}^{u}+\check{w}_{t}^{h} h_{t}^{u}\left(1-\tau_{L, t}\right) \\
& +\check{\Pi}_{t}^{k}+\check{\mathfrak{C}}_{I, t}+\check{\mathfrak{C}}_{P, t}+\frac{1-\iota}{\omega} \check{o}_{t} .
\end{aligned}
$$

The unconstrained household maximizes (10) subject to (11). We obtain a set of standard optimality conditions that are listed in full in the Technical Appendix.

\section{F. Constrained Households}

The lifetime utility function of a financially constrained household is identical to that of an unconstrained household, with the sole exception that the discount factor $\beta_{c}$ is allowed

\footnotetext{
${ }^{27}$ The assumption of transaction costs that are quadratic in the debt-to-output ratio is commonly used in other literatures. The main example is the open economy literature with incomplete asset markets (SchmittGrohé and Uribe (2003), Neumeyer and Perri (2005)). In the closed economy literature, Heaton and Lucas (1996) have used the same device.
} 
to differ from $\beta_{u}$. We have

$$
\operatorname{Max} E_{0} \sum_{t=0}^{\infty} \beta_{c}^{t}\left\{S_{t}^{c}\left(1-\frac{v}{x}\right) \log \left(c_{t}^{c}(i)-\nu c_{t-1}^{c}\right)-\psi \frac{h_{t}^{c}(i)^{1+\frac{1}{\eta}}}{1+\frac{1}{\eta}}+\kappa \log \left(a_{t}^{c}(i)\right)\right\} .
$$

Constrained households can invest in bank deposits $\check{d}_{t}^{c}$ and land $a_{t}^{c}$. However, unlike unconstrained households they cannot finance the desired levels of these assets completely out of their own resources, and therefore have to borrow from banks. The associated consumption and mortgage loans are denoted by $\check{\ell}_{t}^{c}$ and $\check{\ell}_{t}^{a}$. Constrained households' budget constraint in period $t$, in real normalized terms, is given by

$$
\begin{aligned}
& \check{d}_{t}^{c}\left(1+\phi_{b}\left(b_{t}^{r a t}-\bar{b}^{r a t}\right)\right)+\check{p}_{t}^{a} a_{t}^{c}-\check{\ell}_{t}^{c}-\check{\ell}_{t}^{a} \\
= & \frac{r_{d, t}}{x} \check{d}_{t-1}^{c}\left(1-\xi^{c} G_{c, t}\right)+\check{\Lambda}_{t}^{c}-\frac{r_{\ell, t} \check{\ell}_{t-1}^{c}}{x}+\check{p}_{t}^{a} a_{t-1}^{c}\left(1-\xi^{a} G_{a, t}\right)+\check{\Lambda}_{t}^{a}-\frac{r_{\ell, t}^{h}}{x} \check{\ell}_{t-1}^{a} \\
& -\check{c}_{t}^{c}\left(1+s_{t}^{c}\right)\left(1+\tau_{c, t}\right)-\check{\tau}_{t}^{c c}+\check{\varpi}_{t}^{h} h_{t}^{c}\left(1-\tau_{L, t}\right)+\check{\Psi}_{t}^{c}+\frac{\iota}{1-\omega} \check{o}_{t}+\delta^{u} \check{n}_{t}^{u} .
\end{aligned}
$$

The terms on the second line represent the net cash flows from debt-financed investments in bank deposits and land, with $\xi^{c} G_{c, t}$ and $\xi^{a} G_{a, t}$ denoting the shares of gross asset returns spent on monitoring costs, and $\check{\Lambda}_{t}^{c}$ and $\check{\Lambda}_{t}^{a}$ representing banks' net losses (and thus borrowers' gains) on the respective loans. All other terms are familiar, with an appropriate change of notation, from the cash flow of unconstrained households, except for the dividends of unions $\delta^{u} \check{n}_{t}^{u}$, which are assumed to be received only by constrained households. For utility maximization we also need to consider the budget constraint in period $t+1$, which is identical in form to the time $t$ budget constraint, except that the terms on the second row become

$$
\left(1-\Gamma_{c, t+1}\right) \frac{r_{d, t+1}}{x} \breve{d}_{t}^{c}+\left(1-\Gamma_{a, t+1}\right) \check{p}_{t+1}^{a} a_{t}^{c},
$$

where $\left(1-\Gamma_{c, t+1}\right)$ and $\left(1-\Gamma_{a, t+1}\right)$ denote the expected shares of gross returns on deposits and land retained by households, that is after either repaying bank loans or going bankrupt. These terms are familiar from the description of the optimal loan contract studied in subsection III.B. Most of the optimality conditions for constrained households are standard and shown in the Technical Appendix. We list here only the conditions for the optimal consumer loan contracts,

$$
\begin{gathered}
\check{\lambda}_{t}^{c}\left(1+\phi_{b}\left(b_{t}^{r a t}-\bar{b}^{r a t}\right)\right)\left(1-s_{t}^{c^{\prime}}\left(v_{t}^{c}\right)^{2}\right) \\
=E_{t} \frac{\beta_{c}}{x} \check{\lambda}_{t+1}^{c} r_{d, t+1}\left[\left(1-\Gamma_{c, t+1}\right)+\tilde{\lambda}_{t+1}^{c}\left(\Gamma_{c, t+1}-\xi^{c} G_{c, t+1}\right)\right], \\
\check{\lambda}_{t}^{c}=E_{t} \frac{\beta_{c}}{x} \check{\lambda}_{t+1}^{c} \tilde{\lambda}_{t+1}^{c} r_{\ell, t+1},
\end{gathered}
$$

and for optimal mortgage loan contracts,

$$
\begin{aligned}
& \check{\lambda}_{t}^{c}-\frac{\kappa}{\check{p}_{t}^{a} a_{t}^{c}} \\
&= E_{t} \beta_{c} \check{\lambda}_{t+1}^{c} \frac{\check{p}_{t+1}^{a}}{\check{p}_{t}^{a}}\left[\left(1-\Gamma_{a, t+1}\right)+\tilde{\lambda}_{t+1}^{a}\left(\Gamma_{a, t+1}-\xi^{a} G_{a, t+1}\right)\right], \\
& \check{\lambda}_{t}^{c}=E_{t} \frac{\beta_{c}}{x} \check{\lambda}_{t+1}^{c} \tilde{\lambda}_{t+1}^{a} r_{\ell, t+1}^{h} .
\end{aligned}
$$

We observe that these take a very similar form to the optimal loan contract for capital investment funds in (6), except for the presence of a monetary wedge in (13), and of a utility wedge in (14). 


\section{G. Unions}

Unions have unit mass and are indexed by $i$. Each union buys homogenous labor from households at the nominal household wage $W_{t}^{h}$, and sells labor variety $i$ to manufacturers at the nominal producer wage $W_{t}(i)$. Each manufacturer demands a CES composite of labor varieties, with elasticity of substitution $\theta_{w}$, so that unions' gross markup of $W_{t}(i)$ over $W_{t}^{h}$ equals $\mu_{w}=\theta_{w} /\left(\theta_{w}-1\right)$. The aggregate nominal producer wage is given by $W_{t}$. Unions face wage adjustment costs $\mathfrak{C}_{W, t}(i)$ that, as in Ireland (2001), make it costly to change the rate of wage inflation: $\mathfrak{C}_{W, t}(i)=\frac{\phi_{w}}{2} h_{t} T_{t}\left(\frac{W_{t}(i)}{W_{t-1}(i)} / \frac{W_{t-1}}{W_{t-2}}-1\right)^{2}$. Their optimization problem yields a familiar New Keynesian Phillips curve for wages. Unions are owned by constrained households, who receive the full value of the union's cash flow as a dividend in each period.

\section{H. Manufacturers}

Manufacturers have unit mass and are indexed by $j$. Each buyer of manufacturing output demands a CES composite of goods varieties with elasticity of substitution $\theta$, so that manufacturers' gross steady state markup of their nominal price $P_{t}(j)$ over nominal marginal cost $M C_{t}$ equals $\mu=\theta /(\theta-1)$. Manufacturers face price adjustment costs $\mathfrak{C}_{P, t}(i)$ that, as in Ireland (2001), make it costly for them to change the rate of price inflation: $\mathfrak{C}_{P, t}(i)=\frac{\phi_{p}}{2} y_{t}\left(\frac{P_{t}(j)}{P_{t-1}(j)} / \frac{P_{t-1}}{P_{t-2}}-1\right)^{2}$. Demand for manufacturers' output is given by $y_{t}(j)=y_{t}\left(P_{t}(j) / P_{t}\right)^{-\theta}$, while their technology is given by a standard Cobb-Douglas production function in labor and capital $y_{t}(j)=\left(T_{t} h_{t}(j)\right)^{1-\alpha} k_{t-1}(j)^{\alpha}$. Manufacturers need to maintain bank deposits to minimize the transactions costs associated with payments for their inputs. They finance deposits partly out of their own net worth, and partly by borrowing from banks, with their balance sheet constraint given by

$$
\check{d}_{t}^{m}=\check{\ell}_{t}^{m}+\check{n}_{t}^{m}
$$

Manufacturers' time $t$ optimization problem, in nominal terms, is

$$
\begin{aligned}
& \underset{P_{t}(j), h_{t}(j), k_{t}(j), D_{t}^{m}(j), \bar{\omega}_{t+1}^{m}(j), \tilde{\lambda}_{t}^{m}(j)}{M a x} E_{t}\left\{\left[P_{t}(j) y_{t}\left(\frac{P_{t}(j)}{P_{t}}\right)^{-\theta}+\left(1-\Gamma_{m, t+1}\right) i_{d, t} D_{t}^{m}(j)\right.\right. \\
&+M C_{t}\left(\left(T_{t} S_{t}^{a} h_{t}(j)\right)^{1-\alpha} k_{t-1}(j)^{\alpha}-y_{t}\left(\frac{P_{t}(j)}{P_{t}}\right)^{-\theta}\right) \\
&-\left(W_{t} h_{t}(j)+R_{k, t} k_{t-1}(j)\right)\left(1+s_{t}^{m}(j)\right) \\
&\left.-P_{t} T_{t} \mathfrak{F}-P_{t} \mathfrak{C}_{P, t}(i)\right]-\frac{1}{i_{t}^{\ell}} P_{t+1} \mathfrak{C}_{P, t+1}(i) \\
&\left.+\tilde{\lambda}_{t+1}^{m}(j)\left[\left(\Gamma_{m, t+1}(j)-\xi^{m} G_{m, t+1}(j)\right) D_{t}^{m}(j) i_{d, t}-i_{\ell, t} D_{t}^{m}(j)+i_{\ell, t} N_{t}^{m}(j)\right]+\ldots\right\}
\end{aligned}
$$


The first line shows sales revenues plus earnings on deposits net of the share going to banks. This latter expression is familiar from our general exposition of the optimal loan contract in subsection III.B. The second line imposes the constraint that supply equals demand for good $j$. The term on the third line is the input cost of labor and capital, with an added transaction costs term that depends on the amount of deposits held. The first term on the fourth line is a fixed cost, and the remaining terms are inflation adjustment costs. The fifth line is the bank participation constraint.

We assume that all manufacturers have identical initial stocks of bank deposits, loans and net worth. In that case all manufacturers make identical choices in equilibrium, and we can drop the index $j$ in what follows. The optimality conditions for price setting and input choice are standard, except for the presence of a monetary wedge in marginal cost terms. They are shown in the Technical Appendix. We list here only the condition for the optimal loan contract for working capital loans:

$$
E_{t}\left\{\left[\left(1-\Gamma_{m, t+1}\right) i_{d, t}+s_{t}^{m^{\prime}}\left(v_{t}^{m}\right)^{2}\right]+\tilde{\lambda}_{t+1}^{m}\left[\left(\Gamma_{m, t+1}-S_{t+1}^{x} \xi_{t+1}^{m} G_{m, t+1}\right) i_{d, t}-i_{\ell, t}\right]\right\}=0
$$

Similar to the condition for the optimal consumer loan contract, this features a monetary wedge, but it is otherwise identical to the optimality condition for investment loans (6).

Finally, the net worth accumulation of manufacturers is given by

$$
\begin{gathered}
\check{n}_{t}^{m}=\frac{r_{d, t}}{x} \check{d}_{t-1}^{m}\left(1-\xi^{m} G_{m, t}\right)+\check{\Lambda}_{t}^{m}-\frac{r_{\ell, t}}{x} \check{\ell}_{t-1}^{m} \\
+\check{y}_{t}-\left(\check{w}_{t} h_{t}+r_{k, t} \frac{\check{k}_{t-1}}{x}\right)\left(1+s_{t}^{m}\right)-\check{\mathfrak{C}}_{P, t}-\mathfrak{F}-\delta^{m} \check{n}_{t}^{m} .
\end{gathered}
$$

The terms on the first line represent the net cash flow from debt-financed investment in bank deposits, with $\xi^{m} G_{m, t}$ denoting the share of gross returns spent on monitoring costs, and $\check{\Lambda}_{t}^{m}$ representing banks' net losses (and thus borrowers' gains) on the loan. The terms on the second line represent the net cash flow from goods production, including a fixed cost $\mathfrak{F}$, minus the dividend payment.

\section{Capital Goods Producers}

As in Bernanke et al. (1999), the production of the capital good $k_{t}$ is performed by a separate agent that is subject to investment adjustment costs $\mathfrak{C}_{I, t}=\left(\phi_{I} / 2\right) I_{t}\left(I_{t} /\left(I_{t-1} x\right)-1\right)^{2}$, where $I_{t}$ is investment. We obtain a standard Euler equation for optimal investment over time. Capital accumulation is given by $k_{t}=(1-\Delta) k_{t-1}+I_{t}$, where $\Delta$ is the depreciation rate.

\section{J. Capital Investment Funds}

The balance sheet constraint of capital investment funds is given by

$$
q_{t} \check{k}_{t}=\check{n}_{t}^{k}+\check{\ell}_{t}^{k}
$$


The ex-post return to capital is $\operatorname{ret}_{k, t}=\left(r_{k, t}+(1-\Delta) q_{t}-\tau_{k, t}\left(r_{k, t}-\Delta q_{t}\right)\right) / q_{t-1}$, where $\tau_{k, t}$ is the tax rate on capital income. The condition for the optimal loan contract of capital investment funds was shown in (6). Their net worth accumulation takes the by now familiar form

$$
\check{n}_{t}^{k}=\frac{\operatorname{ret}_{k, t}}{x} q_{t-1} \check{k}_{t-1}\left(1-\xi^{k} G_{k, t}\right)+\check{\Lambda}_{t}^{k}-\frac{r_{\ell, t}}{x} \check{\ell}_{t-1}^{k}-\delta^{k} \check{n}_{t}^{k}
$$

\section{K. Government}

\section{Monetary Policy}

Monetary policy is given by a conventional inflation forecast-based interest rate rule

$$
i_{t}=\left(i_{t-1}\right)^{m_{i}}\left(\frac{x}{\beta_{u}} \bar{\pi}\left(1+\phi_{b}\left(b_{t}^{r a t}-\bar{b}^{r a t}\right)\right)\right)^{\left(1-m_{i}\right)}\left(\frac{\pi_{4, t+3}}{(\bar{\pi})^{4}}\right)^{\frac{\left(1-m_{i}\right) m_{\pi}}{4}}
$$

where the second term on the right-hand side is the steady state nominal interest rate, and where $\pi_{4, t}=\pi_{t} \pi_{t-1} \pi_{t-2} \pi_{t-3}$. Under the current monetary regime the government controls an interest rate that affects both money and credit. But this control is quite weak. For credit it operates through the effects, by arbitrage, of the policy rate on the deposit rate. But banks' decisions on lending standards and on spreads over the deposit rate have a much stronger effect on the availability and cost of credit. Because, except for banks' retained earnings, money equals credit under the current monetary system, the effect of the policy rate on money is also weak compared to banks' decisions on lending standards and thus on the overall volume of credit.

\section{Prudential Policy}

We assume that prudential policy under the current monetary regime follows a fixed Basel rule that sets a constant minimum capital adequacy ratio, $\gamma_{t}=\bar{\gamma}$. Alternatives to this assumption are discussed in Benes and Kumhof (2011).

\section{Fiscal Policy}

Fiscal policy follows a structural deficit rule. Specifically, the government's long-run target for the deficit-to-GDP ratio $g d_{t}^{r a t}=\left(\check{b}_{t}^{g}-\check{b}_{t-1}^{g} /\left(x \pi_{t}\right)\right) / g \check{d} p_{t}$ is fixed at $\overline{g d^{r a t}}$. But because of automatic stabilizers the deficit is allowed to fluctuate with the output gap $\ln \left(g \check{d} p_{t} / g d p_{s s}\right)$

$$
g d_{t}^{r a t}=\overline{g d^{r a t}}-d^{g d p} \ln \left(\frac{g \check{d} p_{t}}{g d p_{s s}}\right) .
$$

We assume that the labor income tax rate $\tau_{L, t}$ is adjusted to make this rule hold over the business cycle. But we assume that the other two distortionary tax rates of the model follow labor income tax rates in proportional fashion, by positing the auxiliary rules $\left(\tau_{c, t}-\bar{\tau}_{c}\right) / \bar{\tau}_{c}=\left(\tau_{L, t}-\bar{\tau}_{L}\right) / \bar{\tau}_{L}$ and $\left(\tau_{k, t}-\bar{\tau}_{k}\right) / \bar{\tau}_{k}=\left(\tau_{L, t}-\bar{\tau}_{L}\right) / \bar{\tau}_{L}$. Lump-sum taxes 
are given by $\check{\tau}_{l s, t}=\omega \check{\tau}_{t}^{\mathrm{uu}}+(1-\omega) \check{\tau}_{t}^{c c}$, and we assume that the portion affecting constrained agents is determined by the parameter $f_{c c}$ in $\check{\tau}_{t}^{c c}=f_{c c} \check{\tau}_{t}^{l s} /(1-\omega)$.

Government spending spending $\check{g}_{t}$ is assumed to equal a fixed fraction $s_{g}$ of GDP.

\section{Government Budget Constraint}

The government budget constraint is given by

$$
\check{b}_{t}^{g}=\frac{r_{t}}{x} \check{b}_{t-1}^{g}+\check{g}_{t}-\check{\tau}_{t}
$$

where tax revenue is given by $\check{\tau}_{t}=\tau_{c, t} \check{c}_{t}+\tau_{L, t} \check{w}_{t}^{h} h_{t}+\tau_{k, t}\left(r_{k, t}-\Delta q_{t}\right) \frac{\check{k}_{t-1}}{x}+\check{\tau}_{l s, t}$. For future reference we note that the steady state relationship between debt- and deficit-to-GDP ratios is given by the accounting relationship $\overline{b^{r a t}}=\left(\overline{g d^{r a t}} / 4\right) \frac{x \bar{\pi}}{x \bar{\pi}-1}$, where the factor of proportionality 4 is due to the fact that our model is quarterly.

\section{Market Clearing}

The goods market clearing condition is given by $\check{y}_{t}=\check{c}_{t}+\check{I}_{t}+\check{g}_{t}+\mathfrak{F}+\mathfrak{r}\left(\check{\mathcal{M}}_{t}+\check{\mathcal{T}}_{t}\right)$, where $\mathfrak{r}$ is the fraction of monitoring and transactions costs that represents a real resource cost, and where the remaining fraction $1-\mathfrak{r}$ is a lump-sum transfer to households. The labor market clearing condition is given by $h_{t}=\omega h_{t}^{u}+(1-\omega) h_{t}^{c}$, land market clearing by $a=\omega a_{t}^{u}+(1-\omega) a_{t}^{c}$, where $a$ is the fixed and exogenous supply of land, and bonds market clearing is given by $\omega \breve{b}_{t}^{u}+\breve{b}_{t}^{b}=\check{b}_{t}^{g}$. Finally, aggregate consumption is defined as $c_{t}=\omega c_{t}^{u}+(1-\omega) c_{t}^{c}$, and GDP as $g \check{d} p_{t}=\check{c}_{t}+\check{I}_{t}+\check{g}_{t}$.

\section{The Model under the Chicago Plan}

We now describe the model economy under the Chicago Plan. We will refer to this as the post-transition economy, while the economy under the current monetary regime will be referred to as the pre-transition economy. Except when specifically mentioned in this section, the structures and calibration of the two economies are identical. The transition is assumed to take place in exactly one period, and in this period budget constraints contain additional terms that relate to large one-off stock changes on balance sheets. We therefore introduce a dummy parameter that will be set to $\mathfrak{d}=1$ in the transition period, and to $\mathfrak{d}$ $=0$ in all subsequent periods. Banks, households, manufacturers, and the government exhibit differences under the Chicago Plan, and we now deal with each in turn. As before, we start with banks.

\section{A. Banks}

The key requirement of the Chicago Plan is that banks have to back $100 \%$ of their deposits $\check{d}_{t}$ by government-issued reserves $\check{m}_{t}$ :

$$
\check{d}_{t}=\check{m}_{t} \text {. }
$$


This means that banks cannot lend by creating new deposits. Rather, their loan portfolio now has to be backed by a combination of their own equity and non-monetary liabilities $\check{f}_{t}$. For the reasons discussed in section II.B, we assume that this funding $\check{f}_{t}$ is supplied exclusively by the government treasury, with private agents limited to holding either bank equity or monetary instruments $\breve{d}_{t}$ that do not fund any lending. ${ }^{28}$ We will therefore refer to $\check{f}_{t}$ as treasury credit. Under this funding scheme the government separately controls the aggregate volume of credit and the money supply. The transition to this new balance sheet conceptually takes place in two stages that both happen in a single transition period. In the first stage, banks instantaneously increase their reserve backing for deposits from $0 \%$ to $100 \%$, by borrowing from the treasury, so that $\check{f}_{t}=\check{m}_{t}=\check{d}_{t}$. In the second stage, the government can independently control money $\check{m}_{t}$ and treasury credit $\check{f}_{t}$. It exercises this ability by cancelling all government debt on banks' balance sheets against treasury credit, and by transferring part of the remaining treasury credit claims against banks to constrained households and manufacturers, by way of restricted accounts that must be used to repay outstanding bank loans. This second stage leaves only investment loans $\check{\ell}_{t}^{k}$ outstanding, with money $\check{m}_{t}$ unchanged and treasury credit $\check{f}_{t}$ much reduced. Net interest charges from the previous period remain the responsibility of the respective borrowers. With this, the overall bank balance sheet becomes $\check{\ell}_{t}^{k}+\check{m}_{t}=\check{f}_{t}+\check{d}_{t}+\check{n}_{t}^{b}$, while the credit function of the banking system is simply given by

$$
\check{\ell}_{t}^{k}=\check{f}_{t}+\check{n}_{t}^{b} .
$$

The government affects the price of lending through its control of the interest rate on treasury credit $i_{f, t}$. It can also affect the volume of lending through capital adequacy regulations. But unless those regulations are tight, banks retain considerable power to determine the aggregate quantity of credit. And of course they are completely in charge of choosing the allocation of that credit. There is therefore nothing in the monetary arrangements of the Chicago Plan that interferes with the ability of the private financial sector to facilitate the allocation of capital to its most productive uses.

Other important details change for the banking sector. First, the government sets the nominal interest rate on reserves $i_{m, t}$. We assume that the deposit function of banks is perfectly competitive, and that banks face zero marginal costs in providing deposit services. This means that banks pass $i_{m, t}$ on to depositors one for one, $i_{m, t}=i_{d, t}$. We will therefore describe policy in terms of the government directly setting $i_{d, t}$. Given that private credit is now only extended to capital investment funds, the expression for total loan losses/gains simplifies to $\check{\Lambda}_{t}^{b}=\check{\Lambda}_{t}^{k}$. Capital adequacy regulation now only applies to the credit portion of the balance sheet, but otherwise takes an identical form to the current arrangements. Details are shown in the Technical Appendix. Banks' optimality condition for the optimal volume of loans takes the same form as before, but in this case it determines the spread between the wholesale rate $i_{\ell, t}$ and the government-determined treasury credit rate $i_{f, t}$, rather than between $i_{\ell, t}$ and the privately determined deposit rate $i_{d, t}$.

\footnotetext{
${ }^{28}$ Of course private agents can also hold real assets and government debt. Also, for the case of heterogeneity within household groups, they can lend to or borrow from non-bank investment trusts.
} 
Banks' net worth accumulation is given by

$$
\begin{aligned}
\check{n}_{t}^{b}= & \frac{1}{x}\left(r_{\ell, t} \check{\ell}_{t-1}+r_{\ell, t}^{h} \check{\ell}_{t-1}^{h}+r_{t} \check{b}_{t-1}^{b}-r_{d, t} \check{d}_{t-1}-x \check{\Lambda}_{t}^{b}\right) \\
& -\frac{\chi}{x}\left(\check{\ell}_{t-1}+\check{\ell}_{t-1}^{h}+\check{b}_{t-1}^{b}\right) F_{t}^{b}\left(\bar{\omega}_{t}^{b}\right)-\delta^{b} \check{n}_{t}^{b} \\
& +\frac{1}{x}\left(r_{d, t} \check{m}_{t-1}-r_{f, t} \check{f}_{t-1}\right)-\mathfrak{d} \check{\Delta}_{t}^{n w} .
\end{aligned}
$$

The first two lines are identical to the pre-transition economy, although several of the lagged entries remain at zero after the transition period. The third line is new. The first item is gross interest on the reserve backing of deposits paid by the government to banks. The second item is gross interest on treasury credit paid by banks to the government. The third item is a one-off equity payout in the transition period. The reason for the latter is that, after a large portion of bank loans is bought back by the government at an unchanged MCAR, banks' equity requirements drop significantly, so that banks would ordinarily respond by temporarily reducing their lending margin to run down their equity. An instantaneous equity payout of appropriate size ensures that the loan buy-back has no significant effect on the pricing of the remaining loans. We assume that the excess equity is paid out to shareholders according to the formula

$$
\check{\Delta}_{t}^{n w}=\check{n}_{t-1}^{b}-\bar{\gamma}^{a} \check{\ell}_{t}^{k}
$$

where $\bar{\gamma}^{a}$ is the unchanged steady steady capital adequacy ratio.

In the above analysis we make the simplifying assumption, common in macroeconomic models, that there is no heterogeneity in debt levels across constrained households, or across manufacturers. This is certainly not true in the real world. But it is straightforward to understand the implications of this additional complication. If we make the reasonable assumption that a government would not want to penalize low-debt individuals in a debt buy-back, then the buy-back would take the form of a flat per capita transfer $\breve{d}_{t}^{\text {new }}$ into the above-mentioned restricted private accounts. ${ }^{29}$ For individuals whose outstanding bank debt $\check{\ell}_{t}^{\text {old }}$ exactly equals $\check{d}_{t}^{\text {new }}$ this would exactly cancel the debt as before. But individuals that started out without debt would be left with the full new balance $\check{d}_{t}^{\text {new }}$, while individuals with debt that exceeds $\check{d}_{t}^{\text {new }}$ would be left with the residual debt. To make sure that the balances of net savers do not add to the money supply, they could then be converted into the equity shares or non-monetary debt instruments of the investment trusts envisaged by Simons. Because treasury-funded banks remain at the core of the financial system, these trusts would be less important than envisaged by Simons. But their presence ensures that there is nothing in the monetary arrangements of the Chicago Plan that prevents households and firms from intertemporal smoothing.

\footnotetext{
${ }^{29}$ A flat per capita transfer is a natural starting point for this thought experiment. But it should be clear that the transition to the Chicago Plan would represent a unique opportunity to address some of the serious income inequality problems that have developed over recent decades, by making larger transfers to lower-income households. As shown in Kumhof and Rancière (2010) and Kumhof et al. (2012), such inequalities can make economies more vulnerable to financial crises, and they can contribute to current account imbalances.
} 


\section{B. Households}

Upon the announcement of the transition, due to the full buy-back of household debt by the government, all households become unconstrained. We model previously distinct households as identical post-transition by setting the population share parameter to $\omega_{t}=1$ from the transition period onwards. The new overall budget constraint correctly reflects the inherited assets and liabilities of both household groups. In the transition period households only pay the net interest charges on past debts incurred by constrained households to the banking sector. The principal is instantaneously cancelled against banks' new borrowing from the treasury, after part of the latter has been transferred to the above-mentioned restricted private accounts and then applied to loan repayments. From that moment onwards the household sector has zero net bank debt ${ }^{30}$, while their financial assets consist of government bonds and deposits, the latter now being $100 \%$ reserve backed. Their new budget constraint is

$$
\begin{aligned}
& \left(\check{b}_{t}^{u}+\check{d}_{t}^{u}\right)\left(1+\phi_{b}\left(b_{n e t, t}^{r a t}-\bar{b}^{r a t}\right)\right)+\check{p}_{t}^{a} a \\
= & \frac{r_{t}}{x} \omega_{t-1} \check{b}_{t-1}^{u}+\frac{r_{d, t}}{x}\left(\omega_{t-1} \check{d}_{t-1}^{u}+\left(1-\omega_{t-1}\right) \check{d}_{t-1}^{c}\right)+\check{p}_{t}^{a} a+\check{\Psi}_{t}^{u} \\
& -\check{c}_{t}^{u}\left(1+s_{t}^{u}\right)\left(1+\tau_{c, t}\right)-\check{\tau}_{t}^{l s}+\check{w}_{t}^{h} h_{t}^{u}\left(1-\tau_{L, t}\right) \\
& -\mathfrak{d}\left(1-\omega_{t-1}\right)\left(\frac{r_{\ell, t}}{x}-1\right) \check{\ell}_{t-1}^{c}-\mathfrak{d}\left(1-\omega_{t-1}\right)\left(\frac{r_{\ell, t}^{h}}{x}-1\right) \check{\ell}_{t-1}^{a}+\check{o}_{t}-\mathfrak{d} \tau_{t}^{\text {once }} .
\end{aligned}
$$

The transition-period-only terms on the last line are new relative to the pre-transition period. The first two terms state that households pay the net interest due on consumer loans and mortgages in the transition period. The dividend portion of other income $\check{o}_{t}$ now includes one additional term, $\mathfrak{d} \Delta_{t}^{n w}$. This represents the above-mentioned one-off equity distribution (share buyback) from banks to households in the transition period. The final item on the last line, $\tau_{t}^{\text {once }}$, is a one-off lump-sum tax levied by the government in the transition period. We set $\tau_{t}^{\text {once }}=\Delta_{t}^{n w}$, so that the lump-sum tax taxes away the benefits of the equity distribution. This allows the government to finance the additional treasury credit to banks that is necessary to replace the lost equity, without having to resort to temporarily higher distortionary taxation.

The government-debt-related interest rate premium on financial assets is now determined by $b_{n e t, t}^{\text {rat }}$ rather than $b_{t}^{\text {rat }}$, where

$$
b_{n e t, t}^{r a t}=\frac{\left(\check{b}_{t}^{g}-\vartheta \check{f}_{t}\right)}{4 g \check{d} p_{t}} .
$$

Here $\vartheta$ indicates the weight that investors attach to treasury credit, that is to government assets vis-à-vis the private sector, in computing net government debt. That weight, in our calibration, will be determined by the relative interest burdens of these two financial instruments. Other changes to the budget constraint reflect the fact that all lump-sum transfers and other income are now received by one household group. Also, the monitoring cost term in other income is much reduced due to the cancellation of a large stock of bank loans.

\footnotetext{
${ }^{30}$ Again, with heterogeneity within household groups gross asset and liability positions would continue to exist.
} 


\section{Manufacturers}

For manufacturers, the equations describing the technology, optimal input choice, and inflation dynamics remain unchanged. In the transition period manufacturers only pay the net interest charges on past debt incurred to the banking sector. The principal is instantaneously cancelled against banks' new borrowing from the treasury, after part of the latter has been transferred to the above-mentioned restricted private accounts and then applied to loan repayments. From that moment onwards the manufacturing sector has zero net bank debt. Manufacturers' main financial asset remains bank deposits, which are now fully backed by reserves and thus debt-free. The debt buy-back therefore implies a large increase in the net worth of this sector, which from this moment onwards is financed almost exclusively by equity.

We assume that, post-transition, manufacturers can still smooth business cycle fluctuations through borrowing and lending. But given their much lower credit risk after the debt buy-back, they can now access the market for riskless debt, in the same way as the government. The net steady state level of this borrowing is however zero. ${ }^{31}$ We denote manufacturers' net holdings of riskless debt by $\check{b}_{t}^{m}$. Their post-transition balance sheet is given by

$$
\check{d}_{t}^{m}+\check{b}_{t}^{m}=\check{n}_{t}^{m}
$$

Manufacturers' opportunity cost of holding bank deposits is therefore now given by the spread between the rate on riskless debt and the deposit rate, with optimal money holdings determined by

$$
i_{t}=i_{t}^{d}+s_{t}^{m^{\prime}}\left(v_{t}^{m}\right)^{2} .
$$

Finally, manufacturers' net worth accumulation is now given by

$$
\begin{gathered}
\check{n}_{t}^{m}=\frac{r_{d, t}}{x} \check{d}_{t-1}^{m}+\frac{r_{t}}{x} \check{b}_{t-1}^{m}-\mathfrak{d}\left(\frac{r_{\ell, t}}{x}-1\right) \check{\ell}_{t-1}^{m}-\delta^{m} \check{n}_{t}^{m} \\
+\check{y}_{t}-\left(\check{w}_{t} h_{t}+r_{k, t} \frac{\check{k}_{t-1}}{x}\right)\left(1+s_{t}^{m}\right)-\check{\mathfrak{C}}_{P, t}-\mathfrak{F} .
\end{gathered}
$$

This reflects the absence of a bank lending relationship, and of associated monitoring costs.

\section{Government}

\section{Monetary Policy}

In the pre-transition environment the government only has a single policy instrument, the nominal interest rate on short-term government bonds, to affect both money and credit. As we have discussed, the effect on each is indirect and weak. In the post-transition environment the government directly controls the quantity of money, while its control over credit is still indirect but potentially much more powerful.

\footnotetext{
${ }^{31}$ Similar to households, non-bank investment trusts could accommodate the credit needs of heterogeneous manufacturers.
} 


\section{Money}

For money, the government follows a Friedman money growth rule whereby the nominal quantity of money grows at the constant (gross) rate $\pi_{m}$,

$$
\check{d}_{t}=\pi_{m} \frac{\check{d}_{t-1}}{x \pi_{t}} \text {. }
$$

The main reason why monetarism had to be abandoned in the 1980s is the fact that under the present monetary system the government can only pursue a rule such as (30) for the narrow monetary aggregates under its direct control. This is only effective if there is a stable deposit multiplier that relates broad to narrow monetary aggregates. However, as discussed in section I, the deposit multiplier is a myth. Under the current monetary system, broad monetary aggregates are created by banks as a function, almost exclusively, of their attitude towards credit risk, without narrow aggregates imposing any effective constraint. On the other hand, under the Chicago Plan the rule (30) directly controls the broadest monetary aggregate. In other words, monetarism becomes highly effective at achieving its main objective. This is the main reason why Friedman (1967) was in favor of the $100 \%$ reserve solution.

Furthermore the government, as the sole issuer of money, can directly control the nominal interest rate on reserves, and given our assumptions about banks' technology, this rate is passed on to depositors one for one. We assume, without loss of generality, that the government's long-run deposit rate equals $\bar{\imath}_{d}=1$, in other words the government eventually pays zero interest on money. However, during a brief period following the implementation of the Chicago Plan real interest rates can become excessively volatile if the deposit rate is lowered too fast. For the immediate post-transition period we therefore assume a fixed autoregressive path for the nominal deposit interest rate, with an initial value that equals the privately determined deposit interest rate of the last pre-transition period:

$$
i_{d, t}=\left(1-\rho_{d}\right) \bar{\imath}_{d}+\rho_{d} i_{d, t-1}
$$

\section{Credit}

To control credit growth, policy is assumed to control both the nominal interest rate on treasury credit $i_{f, t}$ and a countercyclical component of capital adequacy requirements $\gamma_{t}$. As the latter falls under prudential policy, it is discussed in the next subsection.

Because inflation is controlled by the money growth rule, control of the nominal interest rate on treasury credit is equivalent to control of the real interest rate on treasury credit, and thus indirectly of the real interest rate on bank credit.

The zero lower bound on the policy interest rate in the present monetary environment binds because at a less than zero nominal interest rate on bonds private agents can switch their investment to cash. This is not a relevant consideration for treasury credit, which is only accessible to banks for the specific purpose of funding investment loans. The policy rate $i_{f, t}$ is therefore not constrained by a zero lower bound. The government thus has the ability to charge banks a negative nominal/real interest rate on treasury credit during severe downturns, and thereby to offset the higher banking spreads (due to higher lending risk) during such periods. The absence of a zero lower bound implies that policy can 
switch to an environment with both zero inflation and very low steady state treasury credit rates, without running the risk of losing the ability to lower rates further during a downturn.

For the purpose of our simulations we again distinguish between two different environments for the policy rate $i_{f, t}$. In the first environment the economy has reached its new post-transition steady state, while in the second we describe the immediate post-transition period. Around the new post-transition steady state we assume a feedback rule

$$
i_{f, t}=\left(\bar{\imath}_{f}\right)^{1-m_{i}}\left(i_{f, t-1}\right)^{m_{i}}\left(\frac{\pi_{4, t+3}}{(\bar{\pi})^{4}}\right)^{\left(1-m_{i}\right) m_{\pi}} .
$$

This has an identical functional form to the pre-transition policy rule (20) for $i_{t}$. But apart from this there are major differences. First, there is no "natural rate" for this policy rate, so that the government is free to choose the steady state rate $\bar{\imath}_{f}$. Second, there is no zero lower bound for $i_{f, t}$. Third, this rate, through the banking system, only affects investment decisions directly. It is therefore easier to use this rate in a targeted fashion if the nature of shocks is known.

The immediate post-transition period is characterized by a fixed autoregressive path that gradually lowers the treasury credit rate from the pre-transition deposit rate $i_{d, t-1}$ to the long-run target $\bar{\imath}_{f}$ :

$$
i_{f, t}=\left(1-\rho_{f}\right) \bar{\imath}_{f}+\rho_{f}\left(\mathfrak{d} i_{d, t-1}+(1-\mathfrak{d}) i_{f, t-1}\right) .
$$

For the simulation of this transition, we are less concerned with the business cycle stabilizing properties of the new policy rate, and therefore ignore policy feedback to inflation. Reintroducing this feature would make only a minimal difference to our results. We assume that the policymaker sets the steady state rate $\bar{\imath}_{f}$ so that in the long-run the steady state rate on wholesale bank lending $\bar{\imath}_{\ell}$ (before risk spreads) equals the steady state rate on government bonds $\bar{\imath}$. In other words, by providing relatively cheap credit the government subsidizes banks to equalize the average funding costs of the government and of the lowest-risk private corporations.

We have found that if the transition to $\bar{\imath}_{f}$ was modelled as taking place very rapidly, the result would be an immediate explosion in investment demand, with highly destabilizing effects, through inflation and real interest rates, on the rest of the economy. We therefore calibrate the speed of the reduction in this interest rate to be fairly slow, by choosing a high value for $\rho_{f}$.

\section{Prudential Policy}

We assume that policy can, if desired, control credit not only through the interest rate on treasury credit, but also through quantitative lending targets. While these targets are assumed to be flexible in that banks make the ultimate decision on the volume of investment loans, policy can nevertheless impose very costly penalties on excessively volatile lending. In our model these penalties are imposed through countercyclical capital adequacy regulations. 
We recall that in the pre-transition economy we had assumed a Basel regime with a constant MCAR, $\gamma_{t}=\bar{\gamma}$. We retain this assumption when simulating the transition to the new steady state of the Chicago Plan. However, when describing the economy's behavior in response to business cycle shocks under the Chicago Plan, we will assume that prudential policy can have a strong countercyclical component.

As shown in Benes and Kumhof (2011), a Basel regime can be made more flexible by responding to the state of banks' balance sheet. However, when banks lend to a variety of different borrowers, and when a variety of different shocks hit the economy, it may become hard to efficiently calibrate the response of a prudential rule to an appropriate target variable. This problem is very much reduced under the Chicago Plan, because banks exclusively finance investment projects. In this case prudential policy can focus on limiting volatility in the amount of approved investment projects. Because the level of investment can be affected by both the price and the quantity of credit, it is preferable to target neither of those variables through the prudential rule, but rather to target the quantity of investment directly. The rule is

$$
\gamma_{t}=\bar{\gamma}\left(\frac{\check{I}_{t}}{\bar{I}}\right)^{p_{\ell}}
$$

where $p_{\ell}>0$. In other words, the minimum reserve requirement is raised, possibly aggressively, when the quantity of investment is at a cyclical high, thereby forcing banks to hold significantly more equity per unit of loans if they decide to approve a very large volume of investment loans. The result is a combination of reduced lending and higher lending rates on the remaining loans. As we will see, this can be an extremely effective way to limit the business cycle effects of banks' attitudes towards credit risk.

\section{Fiscal Policy}

The fiscal policy rule under the Chicago Plan remains unchanged, as do the rules endogenizing tax rates, and the exogenous process for government spending. But because the fiscal rule targets the government deficit, which equals the change in the stock of government debt, it needs to be modified for the transition period. The reason is that at that time there is a large discontinuous change in the stock of government debt, due to the repayment of the government debt held by the banking system. We therefore have

$$
\begin{gathered}
g d_{t}^{r a t}=(1-\mathfrak{d})\left(\overline{g d^{r a t}}-d^{g d p} \ln \left(\frac{g \check{d} p_{t}}{g d p_{s s}}\right)\right)+\mathfrak{d} \Delta_{t}^{b g}, \\
\Delta_{t}^{b g}=4\left(\bar{b}_{t}^{r a t}-\frac{\bar{b}_{t-1}^{r a t}}{x \pi_{t}\left(g \check{d} p_{t} / g \check{d} p_{t-1}\right)}\right),
\end{gathered}
$$

where the last expression follows directly from the long-run relationship between debt and deficits. Note that the long-run debt-to-GDP ratios are here shown with time subscripts, because in the transition period there is an instantaneous and permanent reduction in the steady state debt-to-GDP ratio, due to the buy-back of bank-held government debt against the cancellation of treasury credit. 


\section{Government Budget Constraint}

Relative to the pre-transition government budget constraint (22), the post-transition budget constraint features new terms related to money issuance and treasury credit issuance, as well as one-off stock adjustment terms in the transition period. We have

$$
\begin{gathered}
\check{b}_{t}^{g}+\check{m}_{t}-\check{f}_{t}-\mathfrak{d} \Delta_{t}^{c o m p}=\frac{r_{t}}{x} \check{b}_{t-1}^{g}+\frac{r_{d, t}}{x} \check{m}_{t-1}-\frac{r_{f, t}}{x} \check{f}_{t-1}+\check{g}_{t}-\check{\tau}_{t} \\
\check{\tau}_{t}=\check{\tau}_{l s, t}+\mathfrak{d} \tau_{t}^{\text {once }}+\tau_{c, t} \check{c}_{t}+\tau_{L, t} \check{w}_{t}^{h} h_{t}+\tau_{k, t}\left(r_{k, t}-\Delta q_{t}\right) \frac{\check{k}_{t-1}}{x} .
\end{gathered}
$$

There are two new flow items that play a key role in the fiscal accounts under the Chicago Plan. The first is net seigniorage from government money provision $\check{m}_{t}-\frac{r_{d, t}}{x} \check{m}_{t-1}$, which in a steady state with $\bar{r}_{d}=1$ and a positive growth rate $x$ represents a cash inflow. The second is net cash flow from government credit provision $-\check{f}_{t}+\frac{r_{f, t}}{x} \check{f}_{t-1}$, which in steady state represents a cash outflow when, as we will assume, the government keeps the real interest rate on treasury credit below the growth rate, $\bar{r}_{f}<x$.

The new stock items in the transition period need to be discussed carefully. On impact there is a one-off cash flow $\check{m}_{t}-\check{f}_{t}$. At the moment at which banks purchase their new reserve backing, this cash flow is clearly equal to zero. But we assume that this is instantaneously followed by another set of transactions whereby the government buys back a number of government and private debts by cancelling them against $\check{f}_{t}$, thereby reducing $\check{f}_{t}$. First, there is a one-off negative cash flow $\check{b}_{t}^{g}-\frac{r_{t}}{x} \check{b}_{t-1}^{g}$ that is exactly balanced by a commensurate reduction in $\check{f}_{t}$. This is due to the repayment of government debt held by banks, so that $\check{b}_{t}^{g}$ is significantly smaller than $\check{b}_{t-1}^{g}$. Second, there is a one-off negative cash-flow from the cancellation of the principal of private debts against treasury credit, which again represents a reduction in $\check{f}_{t}$ :

$$
\Delta_{t}^{c o m p}=\left(1-\omega_{t-1}\right)\left(\check{\ell}_{t-1}^{c}+\check{\ell}_{t-1}^{a}\right)+\check{\ell}_{t-1}^{m} .
$$

Third, without an additional tax the government's cash flow in the transition period would suffer from the fact that banks distribute part of their stock of equity $\Delta_{t}^{n w}$ to households in that period, and need to make up the lost funding by borrowing additional funds from the government, thereby raising the required $\check{f}_{t}$. By raising a one-off lump-sum $\operatorname{tax} \tau_{t}^{\text {once }}=\Delta_{t}^{n w}$ that taxes away households' gain from the bank equity distribution, the government's cash flow remains smooth and does not require a large spike in distortionary taxes in the transition period in order to procure the additional funds. A maintained assumption in this argument is of course that the government maintains its fiscal rule at all times. With this set of assumptions the regular flow items of the government's budget constraint remain insulated from the large one-off stock effects of the transition.

In terms of stock items, the government and the private sector share the benefits of replacing debt-based private money with debt-free government-issued money. The government swaps debt for equity, because the large new stock of irredeemable government-issued money represents government equity rather than government debt. This is not traded equity that pays dividends, but rather equity in the commonwealth, whose return comes in the form of lower government interest costs, lower distortionary taxes, and lower financial market monitoring costs. At the same time, treasury credit to 
banks dramatically reduces the government's overall net debt. The non-bank private sector also swaps debt for equity, in this case due to government transfers that increase private sector wealth and reduce debt levels.

\section{Controlling Boom-Bust Cycles - Additional Considerations}

Two additional considerations, both of which have to remain outside the formal model, suggest that the effectiveness of countercyclical policy would be further enhanced under the Chicago Plan relative to present monetary arrangements.

First, banks that are subject to a $100 \%$ reserve requirement know that they cannot create their own funds to fuel a lending boom, but that instead they have to borrow these funds from the government at rates that increase in a lending boom, and that the additional borrowing could furthermore be subject to much higher capital requirements. Arguably this knowledge makes it much less likely that banks will develop their intermittent bouts of optimism and pessimism in the first place.

Second, under the present monetary regime, especially during a boom, capital adequacy requirements impose virtually no effective constraint, because the money that is injected as equity does not need to represent other agents' savings. Instead, any additional funds required as equity by Bank A can simply be created by Bank B as credit to a household, who then injects those funds as equity into Bank A. ${ }^{32}$ This is impossible under the Chicago Plan, as the banking system is unable to create its own funds through credit, while any government credit is specifically earmarked for investment projects. Therefore, just like in the case of the money growth rule, a prudential MCAR rule becomes far more effective under the Chicago Plan.

\section{Calibration}

We calibrate the steady state of our model economy, for the period prior to the transition to the Chicago Plan, based on U.S. data for the period 1990-2006, where available. The reason is that 2006 is the last full year before the onset of the Great Recession, which led to massive fluctuations in many of the data required for our calibration, particularly in balance sheet data. For most of our calibration of the real economy we use data for the full 1990-2006 period to compute averages. However, for balance sheet data, including balance sheets of banks, firms, households and the government, we use a calibration based on the final years preceding the crisis. This is because balance sheets, unlike key ratios in the real economy, have changed dramatically since the early 1990s, so that earlier data are no longer representative as a starting point when trying to evaluate the effects of policies whose immediate impact is on balance sheets. In the interest of space we do not display the data underlying our calibration choices. Detailed figures are shown in the Technical Appendix. One period corresponds to one quarter.

The trend real growth rate $x$ is calibrated at $2 \%$ per annum and the average inflation rate $\bar{\pi}$ at $3 \%$ per annum. The historical average for the real interest rate on U.S. government

\footnotetext{
${ }^{32}$ See Huber (2011).
} 
debt is around $2.5 \%-3.0 \%$ per annum. We calibrate it at $3 \%$ per annum. The population share of unconstrained households is assumed to be $10 \%$, or $\omega=0.1$. The parameter $\iota$, which determines the relative income and therefore consumption levels of unconstrained and constrained household, is fixed to obtain a steady ratio of unconstrained to constrained households' per capita consumption of 4:1, in line with evidence from the U.S. Survey of Consumer Finance. The parameter $\mathfrak{r}$, which determines the share of monitoring and transactions costs that represent real resource costs rather than lump-sum payments back to households, is fixed at $\mathfrak{r}=0.25$.

The labor income share is calibrated at $61 \%$ by fixing $\alpha$. This is in line with recent BLS data for the U.S. business sector. This share has exhibited a declining trend over recent decades, and we therefore base our calibration on the more recent values. The private investment to GDP ratio is set to $19 \%$ of GDP, roughly its average in U.S. data. The implied depreciation rate, at close to $10 \%$ per annum, is in line with much of the literature. The investment adjustment cost parameter, at $\phi_{I}=2.5$, follows Christiano et al. (2005). The price and wage markups of monopolistically competitive manufacturers and unions are fixed, in line with much of the New Keynesian literature, at 10\%, or $\mu_{p}=\mu_{w}=1.1$. Together with the assumptions for the price and wage inflation stickiness parameters of $\phi_{p}=200$ and $\phi_{w}=200$, this implies an average duration of price and wage contracts of 5 quarters in an equivalent Calvo (1983) setup with full indexation to past inflation. This is consistent with the results of Christiano et al. (2005). Unions' dividends are assumed to be fully distributed to constrained households in each period, $\delta_{u}=1$.

The government accounts are calibrated in considerable detail, because the effects of the Chicago plan include a substantial reduction in both gross and net government debt, and large effects on deficits of the previously non-existent items net seigniorage and net new treasury credit. To evaluate the desirability of such a development, it is critical to study its implications for interest rates and for different types of distortionary taxation. The government spending to GDP ratio is set to its approximate historical average of $18 \%$ of GDP. Tax rates on labor, capital and consumption are fixed to reproduce the historical ratios of the respective tax revenues to GDP, which are $17.6 \%$ for labor income taxes, $3.2 \%$ for capital income taxes, and $4.6 \%$ for consumption taxes. The implied initial steady state tax rates are $\tau_{L}=0.317, \tau_{k}=0.259$ and $\tau_{c}=0.073$. The implied steady state value for $\tau_{l s}$ is a lump-sum transfer to households of $6.6 \%$ of GDP, of which constrained households are assumed to receive $95 \%$ by setting $f_{c c}=0.95$. The calibrated value for the government debt-to-GDP ratio, at $80 \%$, is based on the most recent available data. The elasticity of the real interest rate with respect to the level of government debt is calibrated at 3 basis points for each percentage point increase in the government debt-to-GDP ratio. This is consistent with the empirical estimates reported in Laubach (2009), Engen and Hubbard (2004) and Gale and Orszag (2004). Fiscal policy can be characterized by the degree to which automatic stabilizers work, in other words by the size of $d^{g d p}$. This has been quantified by the OECD (Girouard and André (2005)), whose estimate for the United States is $d^{g d p}=0.34$. We adopt this for the business cycle comparison of the pre-transition and post-transition economies, but for the illustration of the transition dynamics without business cycle shocks we simplify by assuming a balanced budget rule with $d^{g d p}=0$. All three distortionary tax rates are assumed to move in proportion. We assume a conventional calibration of the monetary policy rule, similar to what has for example been used in the Federal Reserve's SIGMA model, by setting $m_{i}=0.7$ and 
$m_{\pi}=2.0$. For the prudential rule, we set $p_{\ell}=0$ except for one of the simulations of business cycle shocks in the post-transition economy.

In household preferences, all parameters except for the discount factors are identical across unconstrained and constrained households. We set the labor supply elasticity $1 / \eta$ to one, a common choice in the business cycle literature. The degree of habit persistence is $v=0.7$.

For banks, the parameter $\bar{\gamma}$ determining the Basel minimum capital adequacy ratio is set to $8 \%$ of risk-weighted assets, as under both the Basel II and the new Basel III regulations. ${ }^{33}$ Both Basel II and III regulations feature a $35 \%$ risk weight for residential property and a $100 \%$ risk weight for commercial real estate. We therefore set the parameter $\zeta$, which represents the risk weight for mortgages in the model, to an intermediate value of $\zeta=0.5$. Banks are assumed to maintain an average actual capital adequacy ratio of $10.5 \%$, which means that they maintain a buffer of $2.5 \%$, as envisaged under Basel III. The percentage of banks violating the minimum capital adequacy ratio is set to $2.5 \%$ of all banks per quarter.

Our calibration of the interest rate margin between the policy rate $i_{t}$ and banks' deposit rate $i_{d, t}$ is based on Ashcraft and Steindel (2008), who find a margin of 1.34\%, in 2006, between the average rate of commercial banks' portfolio of treasury and agency securities on the one hand, and their overall portfolio of liabilities on the other hand. We have repeated their computations for a longer time span, and found similar spreads in the 1990s and more recently, but lower spreads from 2001-2004. During that period the policy rate was lowered to unprecedented levels while interest rates on bank liabilities, of which a significant portion is of longer duration, did not drop to the same extent. This in fact suggests that during times of steady policy rates the margin of Ashcraft and Steindel (2008) may be biased downwards because banks' portfolio of liabilities has a longer duration, and thus a larger term premium, relative to their portfolio of government securities. On the other hand, our paper uses a broader concept of deposit-like liabilities than Ashcraft and Steindel (2008), who focus only on commercial banks, while we include all financial institutions that offer liquid liabilities, including the shadow banking system. The liabilities of non-bank financial institutions are less liquid on average than those of commercial banks, and therefore need to offer a larger interest rate. Our compromise calibration is to choose a steady state interest rate margin between $i_{t}$ and $i_{d, t}$ of $1 \%$. Finally, the steady state interest rate margin between the deposit rate $i_{d, t}$ and the rate that banks would charge on riskless private loans $i_{\ell, t}$ is fixed at $1.5 \%$ per annum in steady state. $^{34}$ This means that the margin of the riskless private lending rate over the policy rate is $0.5 \%$, which is roughly equal to the historical spread of the 3-month US\$ LIBOR over the 3-month treasury bill rate. The implied value for penalty costs $\chi$ equals around $0.7 \%$ of the value of assets. This is not an unrealistically large number, because it only applies to the small fraction of banks that do violate the minimum capital adequacy requirement in any given period. As a fraction of the value of total assets of the banking system the penalty only equals $0.02 \%$ per period in steady state.

The overall size of the financial system's balance sheet is calibrated at $200 \%$ of GDP, with liabilities at $184.25 \%$ of GDP and bank equity at $15.75 \%$ of GDP. The figure for liabilities

\footnotetext{
${ }^{33}$ Details on the Basel III regulations are available at http://www.bis.org/bcbs/basel3.htm.

${ }^{34}$ While in the model no borrower is charged the rate $i_{\ell, t}$, it is important as the base lending rate to which different risk-based spreads are added.
} 
is a compromise, in that it exceeds the $100 \%$ of GDP reported for 2006 by the Federal Financial Institutions Examination Council (2007), while it is well below the almost $350 \%$ of GDP reported for safe or information-insensitive financial assets by Gorton et al. (2012). Federal Financial Institutions Examination Council (2007) includes U.S. commercial banks, U.S. branches and agencies of foreign banks, thrift institutions, and credit unions, but it excludes the shadow banking system, while Gorton et al. (2012) include shadow banks. Similar numbers to Gorton et al. (2012) are provided by Pozsar et al. (2010), who use the Flow of Funds database to show that, just prior to the onset of the 2007 crisis, total liabilities of the U.S. commercial banking sector equalled around $100 \%$ of GDP, while the size of the shadow banking sector was around $150 \%$ of GDP, and despite a large subsequent contraction it still exceeded the size of the commercial banking sector in 2010. Gorton (2010) emphasizes that a key component of the shadow banking system is the repo market, but that its size is very hard to estimate reliably due to a lack of comprehensive data coverage. Nevertheless, available estimates for the most recent period range between U.S.\$10 trillion (gross) according to Hördahl and King (2008) and U.S.\$ 12 trillion according to Gorton (2010). Our reason for including at least a conservative estimate of the liabilities of the shadow banking system is that these liabilities perform money-like functions that must not be omitted from a model of the modern U.S. financial system. This is also emphasized by Gorton et al. (2012), who describe the functions of safe or information-insensitive financial sector liabilities as follows: "To the extent that debt is information-insensitive, it can be used efficiently as collateral in financial transactions, a role in finance that is analogous to the role of money in commerce." A large share, and perhaps by now the majority, of financial system debt can therefore command an interest rate discount below the policy rate by yielding these financial, rather than purely goods market, transactions services. Because, in terms of our model, the full menu of safe assets considered by Gorton et al. (2012) ${ }^{35}$, and also by Pozsar et al. (2010), includes items not always intermediated by the financial system (e.g. treasuries) and items that would represent double-counting in a model with a single aggregated banking system (e.g. interbank loans), we adopt the compromise calibration of approximately $185 \%$ of GDP. ${ }^{36}$

This figure also turns out to be approximately consistent with Flow of Funds information on the size of borrowing exposures of the U.S. corporate and household sectors. Just before the onset of the recent crisis, the total amount of credit market debt outstanding for non-financial businesses reached $80 \%$ of GDP, according to the Survey of Consumer Finance (SCF). Ueda and Brooks (2011) show that around 20\%-25\% of this was short-term debt with a maturity of up to one year. We therefore set the steady state values of short-term or working capital loans $\check{\ell}_{t}^{m}$ equal to $20 \%$ of GDP. ${ }^{37}$ We allocate the remaining $60 \%$ of GDP to long-term or investment loans $\check{\ell}_{t}^{k}$. Similarly, just prior to the crisis the ratio of residential mortgages to GDP reached around $80 \%$ of GDP. Our model does not feature housing investment, but rather a fixed factor referred to as land. A

\footnotetext{
${ }^{35}$ The asset categories included in safe assets by Gorton et al. (2012), who use the Federal Reserve's Flow of Funds database, include bank deposits, money market mutual fund shares, commercial paper, federal funds, repurchase agreements, short-term interbank loans, treasuries, agency debt, municipal bonds, securitized debt and high-grade financial sector corporate debt.

${ }^{36}$ Primarily due to the inclusion of the shadow banking system, this figure is much larger than traditional measures of the money supply such as M2, MZM or M3 (discontinued in 2006), with even M3 only reaching around 80 percent of GDP in 2006.

${ }^{37}$ Bates et al. (2008) show that, as in our model, nonfinancial firms simultaneously borrow and hold large amounts of cash, reaching a cash-to-assets ratio of $23.2 \%$ in 2006.
} 
significant portion of housing investment does of course represent the acquisition of the underlying land, and a significant portion of the remainder represents purchases of pre-existing houses where additional investment is only a minor consideration. We find that very important insights can be gained by representing such investment as investment in a fixed factor. On the other hand, housing construction does of course play an important role, and in fact in the official U.S. statistics it is included as part of private investment. Out of the stock of residential mortgages, we therefore allocate one quarter or $20 \%$ of GDP to $\check{\ell}_{t}^{k}$, to represent the housing component of aggregate investment and investment loans, taking the total to $80 \%$ of GDP. We allocate the remaining $60 \%$ of GDP to mortgage loans $\check{\ell}_{t}^{a}$. The Flow of Funds data show that short-term consumer loans reached just under $20 \%$ of GDP prior to the onset of the crisis, and we therefore set $\check{\ell}_{t}^{c}$ to equal $20 \%$ of GDP in steady state. ${ }^{38}$ Finally, the financial system also holds significant amounts of government debt, but, unlike at the time of the Chicago Plan in the 1930s, the majority of U.S. government debt is nowadays held outside the banking system. We therefore calibrate the model so that the domestic financial system holds, and therefore intermediates, government debt equal to $20 \%$ of steady state GDP. This is equal to around $25 \%$ of total outstanding marketable debt. The composition of the liability side of the overall financial system's balance sheet is mainly determined by our assumptions about various agents' leverage, on which we comment next.

Ueda and Brooks (2011) contain information on the leverage or debt-to-equity ratio of all listed U.S. companies. For the overall non-financials group this has fluctuated around $140 \%$ since the early 1990s, while for the core manufacturing and services sectors it has fluctuated around $110 \%$. Leverage for unlisted companies is likely to have been lower on average due to more constrained access to external financing. We therefore choose a steady state leverage ratio of $100 \%$ for both working capital loans and investment loans. For consumer loans, data are not readily available to make a similar determination. We fix leverage for these loans at the same $100 \%$ level as for working capital loans. For mortgages we use data from the Flow of Funds and Fannie Mae to decompose the total value of the U.S. housing stock into its equity and mortgage-debt components. We then deduct one third of the value of the housing stock from the equity component, to account for the fact that one third of U.S. residential property is owned free and clear, based on the 2005 U.S. census. ${ }^{39}$ In our model this mortgage-free component of the housing stock is owned by unconstrained households, and therefore needs to be removed in computing the leverage of constrained households. The ratio of mortgages to the remaining equity equalled around $200 \%$ in the two decades prior to the crisis (since then it has risen dramatically), and we use this to calibrate our steady state.

Steady state interest rate spreads over the policy rate $i_{t}$ are computed from average margins between different corporate and household borrowing rates over 3-month U.S. treasury bill rates. Ashcraft and Steindel (2008) compute, for 2006, a 2\% spread for real estate loans, a $3 \%$ spread for commercial and industrial loans, and a $5 \%$ spread for credit card and other consumption loans. We therefore fix the following steady state spreads: $2 \%$ for mortgage loans, $5 \%$ for consumer loans, $3 \%$ for working capital loans, and $1.5 \%$ for investment loans. Only the latter deviates from Ashcraft and Steindel (2008), principally

\footnotetext{
${ }^{38}$ Laibson et al. (2001) discuss that, as in our model, typical U.S. households simultaneously borrow and hold cash balances.

${ }^{39}$ This information is available at http://www.census.gov/hhes/www/housing/ahs/ahs05/tab3-15.pdf.
} 
because these authors only consider the commercial banking sector, while long-term corporate funding, to the extent that it does not come directly from capital markets, comes to a significant extent from the shadow banking system where spreads tend to be lower. For example, in the commercial paper market average spreads prior to the crisis averaged less than $0.5 \%$.

We calibrate additional parameters by fixing steady state loan default rates at levels that are consistent with the data. Ueda and Brooks (2011) show that the default rate for non-financial listed U.S. companies has averaged around $1.5 \%$ since the early $1990 \mathrm{~s}$. Default rates for smaller, non-listed companies are known to be higher. We therefore set the steady state default rate for investment loans to $1.5 \%$ of all firms per period, and the default rate for working capital loans to $3 \%$. As for household loans, the average personal bankruptcy rate has been just under $1 \%$ over the last two decades. But, as discussed in White (1998), only a fraction of households who default file for bankruptcy, even though in her estimation $15 \%$ of households would benefit financially from doing so. For banks it is often more cost-efficient to simply write off the debt, especially for smaller personal loans. And even for mortgage loans, lenders may be willing to incur significant costs in restructuring the loan before forcing the borrower to resort to the protection of bankruptcy. In our model such plans and associated costs, and not only outright bankruptcy, do represent default events. We therefore fix the steady default rate on mortgages at $2.5 \%$, and on short-term household loans at $4 \%$. These high rates can also be justified by appealing to the U.S. credit score distribution and associated delinquency rates, where delinquency is a $90+$ days late payment on any type of debt. In the United States, $15 \%$ of households fall into a score range that exhibits a delinquency rate of $50 \%$ or more, and another $12 \%$ into a range that exhibits a delinquency rate of around one third.

The interest semi-elasticity of money demand is the percent change in money demand in response to a one percentage point increase in the opportunity cost of holding money. Traditional empirical studies have estimated money demand equations separately rather than as part of an overall general equilibrium model, and have found interest semi-elasticities of -0.05 (Ball (2001)) or even lower (Ireland (2007), O'Brien (2000)). We find that when such elasticities are adopted for a general equilibrium model where money is a very broad aggregate representing all transactions-related (goods and financial markets transactions) liabilities of the financial system, the implications are highly counterfactual. Specifically, a bank lending boom triggered by greater optimism about the creditworthiness of borrowers raises the volume of lending and therefore of deposits. However, despite the fact that lending spreads over the deposit rate fall, with a low interest semi-elasticity the overall cost of lending would rise dramatically, because the increase in deposits would require a much larger increase of deposit interest rates relative to the policy rate. This has not been a feature of interest rate data during lending booms. To the contrary, the data suggest that the marginal depositor is willing to increase his holdings of deposits with little increase in deposit rates relative to policy rates. In other words, the marginal depositor's money demand exhibits a high interest semi-elasticity. We accommodate this by assuming that unconstrained households have an interest semi-elasticity of -1.00. Their money demand can be thought of as representing the demand for liquidity in financial transactions stressed in the recent literature. On the other hand, the money demand of constrained households and of manufacturers represents a more traditional demand for goods and factor market transactions, and for this group 
we therefore adopt the conventional semi-elasticity of -0.05 .

The combination of the above assumptions about capital adequacy, interest margins, leverage and money demand implies the composition of the liability side of the financial system's balance sheet, with equity equal to $15.75 \%$ of $\mathrm{GDP}^{40}$, constrained households' and manufacturers' deposits each equal to $40 \%$ of GDP, and unconstrained households' deposits equal to $104.25 \%$ of GDP. The overall initial steady state balance sheet is shown as the leftmost of three balance sheets in Figure 3.

We now proceed to discuss the calibration of the post-transition economy that operates under the monetary arrangements of the Chicago Plan. We assume that all the main structural parameters are identical to those of the pre-transition economy. The exceptions are mainly due to the fact that the size of post-transition balance sheets is very different. There are also some new policy parameters.

We start with the latter. The nominal growth rate of money $\pi_{m}$ is set equal to the real growth rate of output $x$, which ensures zero inflation in steady state. The steady state net nominal interest rate paid on reserves is set equal to zero, $\bar{\imath}_{d}=1$. The interest rate charged by the government on treasury loans to the banking system is set to ensure that banks' wholesale rate equals the rate on government bonds in steady state, $\bar{\imath}_{\ell}=\bar{\imath}$. The rates at which the deposit and treasury credit rates converge to their new steady state values during the transition period are determined by $\rho_{d}=0.25$ and $\rho_{f}=0.9$. The steady state value of the gross government debt-to-GDP ratio is, following the permanent repayment of the government debt held by the banking system, reduced from $80 \%$ to $60 \%$. The coefficient $\vartheta$ that is used to determine the net government debt-to-GDP ratio, which in turn determines long-run equilibrium real interest rates, is set equal to $\vartheta=0.5$. This takes into account the approximate ratio between the real interest cost on government bonds $\check{b}_{t}^{g}$ and on treasury credit $\check{f}_{t}$. Specifically, steady state nominal (and real) interest rates in the Chicago Plan economy are $1.07 \%$ on government bonds, $0.49 \%$ on treasury credit, and $0 \%$ on deposits.

The monetary policy rule for the treasury credit rate is calibrated identically to the pre-transition rule for the policy rate, $m_{i}=0.7$ and $m_{\pi}=2.0$. For the prudential rule, we set $p_{\ell}=0$ as in the pre-transition economy, but when discussing countercyclical policies we also consider an alternative calibration with $p_{\ell}=8$.

Under our chosen money demand specification, it can be shown that the average interest semi-elasticity of money demand across unconstrained and constrained households in the pre-transition economy is equal to a simple weighted average of their individual semi-elasticities. We set the post-transition money demand coefficients of unconstrained households such that their interest semi-elasticity equals that pre-transition average.

Finally, the balance sheets of banks and manufacturers change dramatically following the stock transactions in the transition period. Our calibration ensures that banks' steady state Basel ratio continues to equal 10.5\%, and that the steady state leverage ratio of manufacturers remains at the $0 \%$ reached immediately after the debt cancellation of the transition period.

\footnotetext{
${ }^{40}$ This is below the $21 \%$ suggested by a simple-minded application of the $10.5 \%$ steady state Basel ratio. The reason is the less than $100 \%$ risk weighting of government bonds and mortgages.
} 


\section{Transition to the Chicago Plan}

In this section we study the reaction of the model economy to the implementation of the Chicago Plan, including its effects in the implementation period itself, and the subsequent adjustment towards a new steady state. This will allow us to study all but the first claim of Irving Fisher (1936) mentioned in the abstract and introduction. The first claim relates to the business cycle properties of the model, and is studied in the next section.

Figure 3 shows bank balance sheets in the transition period. It repeats Figure 1, which is discussed in the introduction, but contains more details concerning the composition of loans and deposits. For continuity with the subsequent discussion, we repeat here the main points made in our discussion of Figure 1. The figure breaks the transition into two separate stages. First, the original balance sheet remains unchanged but banks have to borrow from the treasury to procure the reserves necessary to fully back their deposits. As a result both treasury credit and reserves increase by $184.25 \%$ of GDP. Second, the principal of all of banks' original loans to the government and the private sector, except investment loans, is cancelled against treasury credit in a debt buy-back. Furthermore, banks pay out part of their equity to keep their net worth in line with the now much reduced capital adequacy requirements. The balance sheet on the right of Figure 3 shows that the overall volume of deposits only drops very slightly, with a drop in household deposits nearly matched by an increase in manufacturer deposits. The solid line in that balance sheet represents the now strict separation between the monetary and credit functions of the banking system. The credit function consists only of investment loans, which are financed by a reduced level of equity and by what is left of treasury credit after the buy-backs of other debts. The slight increase in investment loans reflects the beginning of a sustained increase in investment as the economy starts to move towards a new steady state.

Figure 4 shows the full dynamic adjustment of bank balance sheets to the Chicago Plan over the first 60 quarters. In this and all subsequent figures the dotted lines, which jump in the transition period, represent the pre- and post-transition steady states of the model, while the solid lines represent the dynamic adjustment paths. Loans to the private sector and to the government drop by $100 \%$ and $20 \%$ of GDP on impact, with bank net worth dropping by around $7 \%$ of GDP, and treasury credit rising from zero to initially just over $70 \%$ of GDP, to replace deposits and the paid-out equity as the funding source for investment loans. Investment loans subsequently increase by almost $20 \%$ of GDP, but due to the assumed very slow reduction of the cost of treasury credit this adjustment happens very gradually, and therefore does not lead to excessive short-run volatility. It is accompanied by an equally gradual increase in bank net worth that keeps the capital adequacy ratio within a fairly narrow range. The volume of household deposits falls due to a slightly larger spread between bond and deposit rates, while manufacturers' deposits increase due to growing economic activity, with an overall long-run decline in deposits of around $4 \%$ of GDP. Reserves rise from zero to around $180 \%$ of GDP to back this level of deposits. The riskiness of banks drops dramatically, with the share of banks violating the MCAR dropping from $2.5 \%$ to around $0.8 \%$ per period, mainly due to a much lower ratio of funding interest rates to lending rates. Finally, monitoring costs as a share of GDP drop from $2.0 \%$ to $0.7 \%$. In the pre-transition economy extensive monitoring is required to facilitate the private creation of the economy's money stock at an acceptable risk to 
banks. When this is replaced by debt-free government money creation, these monitoring costs, which are costly both because they use significant real resources and because they lead to higher equilibrium real interest rates, become largely unnecessary. The only exception is the monitoring of productive investment projects, which represents a core function of the remaining banking system.

Figure 5 shows the macroeconomic effects of the balance sheet changes illustrated in Figure 4. The post-transition economy exhibits a very large output gain that eventually approaches $10 \%$ for GDP. This is mainly driven by a $27 \%$ increase in investment, and accompanied by an eventually almost $5 \%$ increase in consumption. Over the first few years however consumption drops, because the very rapid increase in investment initially crowds out some consumption. The reason for the large output gain is a combination of lower real interest rates, lower distortionary taxes and lower monitoring costs. The latter has already been discussed, while the other two are illustrated in Figure 5.

The balance sheet changes in Figure 4 cause major drops in equilibrium real interest rates. Gross government debt drops from $80 \%$ to $60 \%$ of GDP, and with treasury credit jumping to around $70 \%$ of GDP on impact, and to $90 \%$ of GDP eventually, unadjusted net government debt immediately, and then increasingly, turns negative. But it is the adjusted net government debt $b_{n e t, t}^{\text {rat }}$ that determines investors' desired real interest rates. Because this net debt applies a weight of $\vartheta=0.5$ to treasury credit, it drops from $80 \%$ of GDP to an eventually very much lower but still positive $16 \%$ of GDP. The consequence is a gradual $1.93 \%$ per annum reduction in real bond and deposit rates, with an additional $3 \%$ per annum reduction in the corresponding nominal rates due to the elimination of steady state inflation. The reduction in the nominal deposit rate is allowed to happen almost instantaneously, while the nominal treasury credit rate, which is shown in Figure 5 relative to the initial nominal deposit rate, is only allowed to fall very gradually. This credit policy is desirable because of its effects on the dynamics of investment. An investment boom begins immediately upon the implementation of the Chicago Plan, due to much lower tax rates, most importantly capital income tax rates, made possible by the favorable fiscal effects of the plan (see below). An initial slight increase in the treasury credit rate, and therefore in the real lending rate on investment loans, followed by a gradual rate reduction, insures that this boom does not become too rapid and destabilizing. The extent of the ultimate drop in the treasury credit rate is determined by the government's objective to subsidize banks' funding costs in order to equalize the real wholesale rate and the real government bond rate. This requires an eventual drop in the real treasury credit rate of $1.51 \%$ per annum, to $0.49 \%$ per annum, which compares to a $2 \%$ per annum drop, to $0 \%$, in the real deposit rate. Real wholesale lending rates eventually drop even further than bond and deposit rates, by $2.43 \%$ per annum. Retail real rates on investment loans on the other hand drop somewhat less, by $1.64 \%$ per annum, because corporate leverage increases in the new steady state, which calls for a higher external finance premium.

Figure 5 also illustrates the third reason for the output gains under the Chicago Plan, very large drops in distortionary tax rates, by almost 5 percentage points for the labor income tax rate, 4 percentage points for the capital income tax rate, and just over one percentage point for the consumption tax rate. The explanation requires a detailed analysis of the budgetary implications of the Chicago Plan, which is shown in Figure 6 . 
Figure 6 illustrates the dramatic beneficial effect of the Chicago Plan on government finances. ${ }^{41}$ Debt service, that is net nominal interest charges on government debt, drops by $4.2 \%$ of GDP. Only a small part of this is due to the 20 percentage point reduction in government debt, while the major part is due to a large drop in nominal interest rates from $6 \%$ per annum pre-transition to just over $1 \%$ per annum post-transition. More than half of this is in turn due to the $3 \%$ per annum reduction in inflation, with the remainder due to much lower real interest rates. The reduction in inflation is the main reason why the government is able to reduce its deficit ratio by $2.8 \%$ of $\mathrm{GDP}^{42}$, while the reduction in real interest rates on the gross debt is sufficient to finance the government's issuance of net new treasury credit at favorable real interest rates. Treasury credit requires an ongoing budgetary expenditure of $1.3 \%$ of GDP because its $0.49 \%$ real interest rate is below the economy's $2 \%$ growth rate. The two main remaining budget items, seigniorage and tax revenue, are equal but of opposite sign. Government issuance of a large stock of reserves allows it to collect seigniorage equal to $3.6 \%$ of GDP. This number is so large not because of an inflation tax, given that inflation is zero in steady state, but rather because of the large size of the stock of reserves at over $180 \%$ of GDP, combined with the fact that $2 \%$ per annum economic growth exceeds the zero nominal and real rate paid on reserves. ${ }^{43}$ The government is assumed to use this new source of revenue to finance a reduction in distortionary taxes equal to $3.6 \%$ of GDP. This is the reason for the above-mentioned drops in tax rates. It should be added that other ways of spending the additional seigniorage revenue could be considered, including spending on public infrastructure. Finally, government spending remains constant as a share of GDP, while transfers are kept constant in real terms and therefore decline by 0.6 percentage points relative to GDP.

We therefore conclude that Fisher's (1936) claims (2) through (4) regarding the Chicago Plan, as listed in the abstract of this paper, are validated by our model.

First, bank runs can obviously be completely eliminated, as bank solvency considerations are no longer an issue in the safety of bank deposits, because money is now debt-free and therefore independent of banks' performance in the credit part of their business. A run on the credit part of banks' business is impossible because banks' debt liabilities are held by the government. A run on the investment trusts discussed in Section IV.A needs to be ruled out through strict and effective regulations, or by insisting on equity investment trusts.

Second, government debt net of treasury credit goes from being highly positive to highly negative if unadjusted for the real interest burden, and to a positive but much smaller fraction of GDP if adjusted for that burden. The large new stock of government-issued money is irredeemable, and represents equity rather than debt.

Third, private debts can be dramatically reduced, because money creation no longer requires simultaneous debt creation. In principle, net private debts in our model could be

\footnotetext{
${ }^{41}$ Several subplots of Figure 6 show a gap in the transition period. This concerns all flow variables that represent changes in financial stocks, given that the latter exhibit large jumps in the transition period. Showing these values in the transition period would render the remaining values unreadable.

${ }^{42}$ This follows mechanically from the fact that the factor of proportionality between long-run deficit- and debt-to-GDP ratios is the steady state nominal growth rate.

${ }^{43} \mathrm{~A}$ small positive steady state inflation rate, even if considered acceptable for non-budgetary purposes, would not generate additional fiscal revenue. In fact, due to the high interest elasticity of money demand at the margin, it would reduce seigniorage income.
} 
reduced to almost zero if the government were to also cancel investment loans against treasury credit. But the monitoring of industrial projects is a core and highly useful function of banks in which they should continue to be involved, even though some authors, like Simons (1946), might argue that this could best be accomplished by equity mutual funds rather than by banks. However, all other pre-transition lending activities of banks in our model served the sole purpose of mortgaging various types of assets in order to be able to create a debt-based money supply at an acceptable risk to banks. This is not necessary, because providing a money supply does not need to involve risk. It can instead be done by the sovereign, debt-free, at much lower cost.

By validating these claims in a rigorous, microfounded model, we were able to establish that the advantages of the Chicago Plan go even beyond those identified by Fisher (1936). First, output gains are very large, approaching ten percent, due to a combination of lower real interest rates, lower distortionary tax rates, and lower monitoring costs in the banking system. Second, the model provides a compelling answer to those who claim that giving the government the power to issue such a large stock of money would be highly inflationary. The opposite is true. Not only does Fisher's proposal not imply any increase in the stock of money held by the private sector, and therefore by construction no increase in nominal spending power, but furthermore it allows the government to achieve much lower steady state inflation without any risk of falling into a liquidity trap.

A liquidity trap is a situation where monetary policy loses its ability to stimulate the economy, either because it is unable to increase broad monetary aggregates (which lead the business cycle) when banks will not lend, or because it is unable to lower nominal interest rates when the zero lower bound is reached. Under the Chicago Plan the government directly controls broad monetary aggregates, and a monetarist money growth rule becomes a highly effective policy tool to control nominal aggregate demand. This rule can ensure zero steady state inflation. At the same time, the policy interest rate does not represent the opportunity cost of money, but rather the cost of a very specific type of credit that is only available to banks. There is therefore no problem with this rate entering negative territory, which it would do more frequently at zero steady state inflation. Of course this presupposes that banks can be prevented from borrowing from the treasury for the purpose of investing in reserves, or in other words that treasury credit can be guaranteed to strictly only be disbursed to finance investment projects. That however does not need to be difficult to do.

\section{Credit Booms and Busts Pre-Transition and Post-Transition}

Figure 7 illustrates how the pre-transition and post-transition monetary regimes cope with a credit boom-and-bust cycle driven by volatile bank sentiment concerning borrower risk. Specifically, we construct a standardized experiment whereby banks receive a succession of "good news" shocks $\varepsilon_{t}^{\text {news }}$ whereby the standard deviation of the riskiness of all their borrowers falls gradually and cumulatively by $60 \%$ by the end of quarter 12 . For the post-transition economy this only concerns $\sigma_{t}^{k}$, the riskiness of investment loans, while for the pre-transition economy we assume that all four standard deviations are reduced by a 
common factor. Especially for the pre-transition economy, this shock leads to a very large three-year expansion in bank credit. We assume that in quarter 13 banks suddenly reverse their assessment of borrower riskiness. They not only start to completely discount the "news" previously revealed, which otherwise would have continued to support strong lending until petering out after another 12 quarters, but they also now perceive an additional adverse autocorrelated shock to borrower riskiness $\varepsilon_{t}^{z 2}$. The net effect is to make borrower riskiness jump from $40 \%$ of its steady state value to $125 \%$ of its steady state value in period 13 , after which it gradually reverts back to the steady state value. This simulation, which uses borrower riskiness shocks in a very similar way to Christiano et al. (2011) and Christiano et al. (2010), captures a highly realistic phenomenon that has been repeatedly observed throughout history, as detailed in section II. In a credit boom banks tend to compete with each other in providing easy credit and discounting lending risk, and the availability of credit and associated economic expansion create the very conditions that make optimism about borrower riskiness look justified. But there comes a point where the debt burdens of borrowers have become so widespread and so large that nervousness sets in about their ability to repay. At that point the perception of borrower riskiness can suddenly turn, and again this sharp contraction of credit creates the very conditions that justify the pessimism. This sudden change in the perception of borrower riskiness is the model's simplified way of capturing the economy's "Minsky moment" (Minsky (1986)).

But different monetary regimes cope with this shock in very different ways. The solid line in Figure 7 shows the response of the pre-transition economy. Bank loans grow very strongly over the initial boom period, by over $50 \%$ of GDP, and banks endogenously create the corresponding bank deposits to "fund" the additional lending. A decomposition shows that about $70 \%$ of the additional lending is due to higher mortgage loans, while the remaining three loan types account for approximately another $10 \%$ each. The reason why mortgages grow so strongly is the fact that the asset securing the loan is neither limited by the amount of the loan itself, as is the case for consumer and working capital loans that are backed by credit-based money, nor does the asset have to be produced first, subject to adjustment costs, as for investment loans. Rather, land already exists in unencumbered form on the balance sheet of unconstrained households, and easier credit terms simply enable constrained households to purchase this land from them, on credit created by banks against the security of that land. Unconstrained households instantaneously exchange their land against the additional bank deposits, while constrained households end up with additional land, of which they initially hold a lower amount due to their borrowing constraint. Unconstrained households end up awash with liquidity, and therefore increase their consumption. This is the main reason why both consumption and investment increase strongly under the pre-transition monetary regime. But deposits increase more generally across the economy, albeit by smaller amounts than for unconstrained households, because the lending expansion across all borrower classes creates large amounts of additional money. During this boom phase investment gradually grows by $2.5 \%$ relative to its trend, while consumption grows by $1.5 \%$, with GDP ending up just under $2 \%$ higher at the end of quarter 12 . At the peak of the boom the inflation rate exceeds its target by over $3 \%$ per annum, and the real policy rate has risen by $2 \%$ per annum. 
Compared to the cumulative gains of the boom phase, the credit contraction at the end of the third year has much larger negative effects on activity, with output dropping by over $5 \%$, consumption by around $3 \%$, and investment by well over $10 \%$. The main reason for this is not that the shock to creditworthiness at that point is around $30 \%$ larger than the cumulative shock over the first three years. Rather, what matters is the suddenness of the reversal. Households have no choice but to respond to the sudden destruction of money with an equally sudden contraction in consumption. More importantly, banks make very large lending losses, with capital adequacy ratios dropping by well over 2 percentage points, and more than $20 \%$ of all banks violating the MCAR. This leads to an approximately $2 \%$ per annum increase in the wholesale real lending rate as banks try to rebuild their capital base, and to an even larger 5\% per annum increase in the average real retail lending rate as banks require compensation for higher lending risk. This increase in lending rates across all borrower categories is the main reason why aggregate activity contracts, with investment being more seriously affected than consumption.

The dashed blue line in Figure 7 illustrates the response of the economy under the Chicago Plan, under the assumption that the government pursues an interest rate rule for the treasury credit rate, but that it does not pursue quantitative lending targets through countercyclical capital adequacy regulations. The first important observation is that the quantities of credit and money now evolve completely independently of each other.

Because debt is now much less pervasive throughout the economy, and especially because "pawnbroking" loans that create money on the security of land or deposits are no longer observed, the increase in credit is now much smaller as a share of GDP. Investment loans do rise, and continue rising until well after the negative shock hits in period 13, because the capital stock that requires continued financing only declines gradually thereafter, while bank net worth declines immediately due to lending losses, as in the pre-transition economy. The fluctuations in GDP in this economy are almost identical to those in the pre-transition economy, but the underlying fluctuations in consumption and investment are different. Because only investment is now subject to borrower riskiness shocks, an increase in banks' optimism now has much larger effects on investment, while consumption is not directly affected by increased lending, and is crowded out by higher investment. The treasury credit rate responds to higher inflation with a similar behavior to the policy rate in the pre-transition economy, but with a large swing during the credit bust that takes it well into negative territory, in real but especially in nominal terms. As emphasized above, under the Chicago Plan this does not need to be problematic because there is no zero lower bound for the policy rate. Nevertheless, despite these large swings in the treasury credit rate, the economy remains volatile. The much larger increase in the capital stock relative to its long-run equilibrium value under this scenario implies that the reversal of lending optimism has a larger effect on the valuation of capital, and therefore leads to larger losses at that time. As this impairs banks' capital adequacy more severely, it leads to a larger spike in the wholesale rate, but the main effect is a much larger spike in the retail lending rate to compensate banks for temporarily elevated credit risk. The highly volatile investment under this scenario would likely be considered undesirable by policymakers. A much more aggressive interest rate response would make nominal treasury credit rates far more volatile, which may also be undesirable. The problem is that an exclusively price-based credit policy still gives banks a great deal of discretion to choose the overall volume of lending. To avoid this and stabilize the economy more effectively, policy needs to avail itself of an additional quantitative tool. This however is readily available. 
The red dotted line in Figure 7 illustrates this possibility. The government is now assumed to pursue flexible quantitative lending targets via aggressive countercyclical adjustments of minimum capital adequacy requirements for banks. ${ }^{44}$ As stressed in Section IV.D.3, MCAR are a far more effective tool under the Chicago Plan, because the banking system is unable to endogenously create its own equity. In this simulation, banks have to raise their capital adequacy ratio from $10.5 \%$ to $15 \%$ during the boom, so that the wholesale lending rate, and thus also the retail lending rate, remains very much higher during that time. As a result the increase in investment is only one third as large, with a commensurate reduction in the fluctuations in consumption. At the time of the reversal in lending optimism this makes the economy far more resilient, first because capital investment funds are now much less exposed to a collapse in their asset values, and second because banks are far more resilient and can respond to the shock by reducing their capital adequacy ratio from a very comfortable level. As a result the spike in lending rates under this scenario is also much milder, and smaller than in the pre-transition environment, while the treasury credit rate can be far less volatile. Finally, the amplitude of GDP fluctuations throughout the entire boom-bust cycle is about half that under the other two scenarios.

We conclude that Fisher's claim (1) regarding the advantages of the Chicago Plan can also be validated, provided policy avails itself of the appropriate tools. What that means is that policy does not just use a countercyclical policy for the interest rate at which the treasury makes credit available to lenders, but also direct targets for the quantity of lending, to prevent excessive volatility in the quantity of investment projects approved by lenders.

\section{Conclusion}

This paper revisits the Chicago Plan, a proposal for fundamental monetary reform that was put forward by many leading U.S. economists at the height of the Great Depression. Fisher (1936), in his brilliant summary of the Chicago Plan, claimed that it had four major advantages, ranging from greater macroeconomic stability to much lower debt levels throughout the economy. In this paper we are able to rigorously evaluate his claims, by applying the recommendations of the Chicago Plan to a state-of-the-art monetary DSGE model that contains a fully microfounded and carefully calibrated model of the current U.S. financial system. The critical feature of this model is that the economy's money supply is created by banks, through debt, rather than being created debt-free by the government.

Our analytical and simulation results fully validate Fisher's (1936) claims. The Chicago Plan could significantly reduce business cycle volatility caused by rapid changes in banks' attitudes towards credit risk, it would eliminate bank runs, and it would lead to an instantaneous and large reduction in the levels of both government and private debt. It would accomplish the latter by making government-issued money, which represents equity in the commonwealth rather than debt, the central liquid asset of the economy, while banks concentrate on their strength, the extension of credit to investment projects that require monitoring and risk management expertise. We find that the advantages of the

\footnotetext{
${ }^{44}$ The lending volume of the aforementioned non-bank investment trusts could also be regulated by countercyclical capital adequacy requirements.
} 
Chicago Plan go even beyond those claimed by Fisher. One additional advantage is large steady state output gains due to the removal or reduction of multiple distortions, including interest rate risk spreads, distortionary taxes, and costly monitoring of macroeconomically unnecessary credit risks. Another advantage is the ability to drive steady state inflation to zero in an environment where liquidity traps do not exist, and where monetarism becomes feasible and desirable because the government does in fact control broad monetary aggregates. This ability to generate and live with zero steady state inflation is an important result, because it answers the somewhat confused claim of opponents of an exclusive government monopoly on money issuance, namely that such a monetary system would be highly inflationary. There is nothing in our theoretical framework to support this claim. And as discussed in Section II, there is very little in the monetary history of ancient societies and Western nations to support it either. 


\section{References}

Allais, M. (1947), Économie et Intérêt: Présentation nouvelle des problèmes fondamentaux relatifs au rôle économique du taux de l'intérêt et de leurs solutions, 2 vols., Paris: Librairie des Publications Officielles.

Angell, J. (1935), "The 100 Per Cent Reserve Plan", Quarterly Journal of Economics, 50, 1-35.

Angeloni, I. and Faia, E. (2009), "A Tale of Two Policies: Prudential Regulation and Monetary Policy with Fragile Banks", The Kiel Institute for the World Economy Working Paper Series, No. 1569.

Aoki, K., Proudman, J. and Vlieghe, G. (2004), "House Prices, Consumption, and Monetary Policy: A Financial Accelerator Approach", Journal of Financial Intermediation, 13(4), 414-435.

Ashcraft, A.B. and Steindel, C. (2008), "Measuring the Impact of Securitization on Imputed Bank Output", Working Paper, Federal Reserve Bank of New York.

Ball, L. (2001), "Another Look at Long-Run Money Demand", Journal of Monetary Economcics, 47, 31-44.

Bates, T., Kahle, K. and Stulz, R. (2008), "Why do U.S. firms hold so much more cash than they used to?", Working Paper, Ohio State University.

Benes, J. and Kumhof, M. (2011), "Risky Bank Lending and Optimal Capital Adequacy Regulation", IMF Working Paper WP/11/130.

Bentham, J. (1818), Defense of Usury, London: Payne \& Foss.

Berkeley, G. (1735), Querest, London: Innis, Davis \& Hitch, 1750.

Bernanke, B., Gertler, M. and Gilchrist, S. (1999), "The Financial Accelerator in a Quantitative Business Cycle Framework", in: Taylor, J.B., Woodford, M. (eds.), Handbook of Macroeconomics, Volume 1C. Elsevier, Amsterdam, pp. 1341-1393.

Berry, S., Harrison, R., Thomas, R. and de Weymarn, I. (2007), "Interpreting Movements in Broad Money", Bank 2of England Quarterly Bulletin, 2007 Q3, 47(3), 376-88, Monetary Analysis Division, Bank of England.

Black, W. (2005), The Best Way to Rob a Bank Is to Own One: How Corporate Executives and Politicians Looted the SEL Industry, University of Texas Press.

Butler, B. (1869), Speech in the House of Representatives, Congressional Globe, 40th Congress, 3rd Session, pp. $303 \mathrm{ff}$.

Calvo, G.A. (1983), "Staggered Prices in a Utility-Maximizing Framework", Journal of Monetary Economics, 12, 383-398. 
Carpenter, S. and Demiralp, S. (2010), "Money, Reserves, and the Transmission of Monetary Policy: Does the Money Multiplier Exist?", Finance and Economics Discussion Series, No. 2010-41, Divisions of Research \& Statistics and Monetary Affairs, Washington, DC: Federal Reserve Board.

Christiano, L. J., Eichenbaum, M. and Evans, C. L. (2005), "Nominal Rigidities and the Dynamic Effects of a Shock to Monetary Policy," Journal of Political Economy, 113(1), 1-45.

Christiano, L., Motto, R. and Rostagno, M. (2011), "Financial Factors in Economic Fluctuations", Working Paper.

Christiano, L., Trabandt, M. and Walentin, K. (2010), "Introducing Financial Frictions and Unemployment into a Small Open Economy Model", Sveriges Riksbank Working Paper Series, No. 214.

Curdia, V. and Woodford, M. (2010), "Credit Spreads and Monetary Policy", Journal of Money, Credit and Banking, 24(6), 3-35.

Currie, L. (1934), "A Proposed Revision of the Monetary System of the United States", submitted to the Secretary of the Treasury Henry Morgenthau, September, reprinted in Currie (1968), The Supply and Control of Money in the United States, New York: Russell and Russell.

Cutting, B. (1934), "Is Private Banking Doomed?", Liberty (May), pp. 7-10.

Del Mar, A. (1895), History of Monetary Systems, reprint: New York, A.M. Kelley (1978).

Dempsey, B. (1948), Interest and Usury, London: Denis Dobson.

Dillaye, S. (1877), Assignats and Mandats: A True History, Philadelphia: Henry Carey Baird.

Douglas, P. (1935), Controlling Depressions, New York: W.W. Norton \& Co., Inc.

Einzig, P. (1966), Primitive Money, New York: Pergamon.

Engen, E.M. and Hubbard, R.G. (2004), "Federal Government Debt and Interest Rates", NBER Macroeconomics Annual, 19, 83-138.

Federal Accounting Standards Advisory Board (2012), Federal Accounting Standards Advisory Board Handbook, Statements of Federal Financial Accounting Standards 7, pp. 106-107.

Federal Bureau of Investigations (2007), "2007 Mortgage Fraud Report", available at http://www.fbi.gov/stats-services/publications/mortgage-fraud-2007/mortgagefraud-2007.

Federal Financial Institutions Examination Council (2007), Annual Report 2006, 
Washington, DC.

Fisher, I. (1935), "100\% Money: Designed to keep checking banks 100\% liquid; to prevent inflation and deflation; largely to cure or prevent depressions; and to wipe out much of the National Debt", New York: The Adelphi Company.

Fisher, I. (1936), "100\% Money and the Public Debt", Economic Forum, Spring Number, April-June 1936, 406-420.

Foxwell, H. (1917a), "The Nature of the Industrial Struggle", Economic Journal, 27, $323-27$.

Foxwell, H. (1917b), "The Financing of Industry and Trade", Economic Journal, 27, 502-15.

Franklin, B. (1729), Modest Inquiry into the Nature and Necessity of a Paper Currency.

Franklin, B. (1786), "The Retort Courteous", in Franklin, W., 1819, The Posthumous and Other Writings of Benjamin Franklin, London: A.J. Valpy, p. 488.

Friedman, M. (1960), A Program for Monetary Stability, New York: Fordham University Press.

Friedman, M. (1967), "The Monetary Theory and Policy of Henry Simons", The Journal of Law and Economics, 10.

Friedman, M. and Schwartz, A. (1963), A Monetary History of the United States, 1867-1960, Washington, DC: National Bureau of Economic Research.

Furfine, C. (2001), "Bank Portfolio Allocation: The Impact of Capital Requirements, Regulatory Monitoring, and Economic Conditions", Journal of Financial Services Research, 20(1), 33-56.

Gale, W. and Orszag, P. (2004), "Budget Deficits, National Saving, and Interest Rates", Brookings Papers on Economic Activity, 2, 101-187.

George, H. (1884), Social Problems, New York: Schalkenbach Foundation, 1992, p. 168.

Gerali, A., Neri, S., Sessa, L. and Signoretti, F. (2010), "Credit and Banking in a DSGE Model of the Euro Area", Bank of Italy Working Paper Series, No. 740.

Gertler, M. and Karadi, P. (2010), "A Model of Unconventional Monetary Policy", Working Paper, New York University.

Girouard, N. and André, C. (2005), "Measuring Cyclically-Adjusted Budget Balances for OECD Countries", OECD Economics Department Working Papers, No. 434.

Gorton, G. (2010), "Questions and Answers about the Financial Crisis", Working Paper, Yale School of Management.

Gorton, G., Lewellen, S. and Metrick, A. (2012), "The Safe-Asset Share", NBER 
Working Paper No. 17777.

Gouge, W. (1833), A Short History of Paper Money and Banking, Philadelphia: T. Ustik.

Graeber, D. (2011), Debt: The First 5000 Years, Melville House Publishers.

Graham, F. (1936), "Partial Reserve Money and the 100 Per Cent Proposal", American Economic Review, 428-40.

Heaton, J. and Lucas, D. (1996), "Evaluating the Effects of Incomplete Markets on Risk Sharing and Asset Pricing", Journal of Political Economy, 104(3), 443-487.

Hördahl, P. and King, M. (2008), "Developments in Repo Markets During the Financial Turmoil", BIS Quarterly Review, 37-53.

Huber, J. (2011), Monetäre Modernisierung, Marburg: Metropolis Verlag.

Hudson, M. and van de Mierop, M. (2002), eds., Debt and Economic Renewal in the Ancient Near East, Bethesda, MD: CDL Press, pp. 7-58.

Ireland, P. (2001), "Sticky-Price Models of the Business Cycle: Specification and Stability", Journal of Monetary Economics, 47, 3-18.

Ireland, P. (2007), "On the Welfare Cost of Inflation and the Recent Behavior of Money Demand", Working Paper, Boston College.

Jefferson, T. (1803), Letter to Treasury Secretary Gallatin, December, in William Parker, ed., Thomas Jefferson: Letters and Addresses, New York.

Jowett, B. (1937), translation of Dialogues of Plato, Socrates dialogue Eryxias, p. 814, New York: Random House.

Keen, S. (2011), Debunking Economics: The Naked Emperor Dethroned?, draft of second edition, pp. 323-325.

Keister, T. and McAndrews, J. (2009), "Why Are Banks Holding So Many Excess Reserves?", Federal Reserve Bank of New York, Staff Report No. 380.

Keynes, M. (1929), "The German Transfer Problem", in Readings in the Theory of International Trade, 1949, Philadelphia and Toronto: The Blakiston Company.

Knapp, G.F. (1924), The State Theory of Money, translation of the original German Staatliche Theorie des Geldes (1905), London: Macmillan \& Co., Ltd.

Knight, F. (1927), "Review of Frederick Soddy's 'Wealth, Virtual Wealth, and Debt'”, The Saturday Review of Literature (April 16), p. 732.

Knight, F. (1933), "Memorandum on Banking Reform", March, Franklin D. Roosevelt Presidential Library, President's Personal File 431.

Knox, J. (1903), History of Banking in the United States, New York: Rhodes, Bradford 
\& Youngman.

Kumhof, M. and Rancière, R. (2010), "Inequality, Leverage and Crises", IMF Working Paper WP/10/268.

Kumhof, M., Lebarz, C., Rancière, R., Richter, A. and Throckmorton, N. (2012), "Income Inequality and Current Account Imbalances", IMF Working Paper $\mathrm{WP} / 12 / 08$.

Kydland, F. and Prescott, E. (1990), "Business Cycles: Real Facts and a Monetary Myth", Federal Reserve Bank of Minneapolis Quarterly Review, 14(2), 3-18.

Laibson, D., Repetto, A. and Tobacman, J. (2001), "A Debt Puzzle", Working Paper.

Laubach, T. (2009), "New Evidence on the Interest Rate Effects of Budget Deficits and Debt", Journal of the European Economic Association, 7(4), 858-885.

Laum, B. (1924), Heiliges Geld, Tübingen: J.C.B. Mohr.

Locke, J. (1692), Considerations on the Consequences of Lowering Interest, London, reprinted in McCulloch, Principles of Political Economy.

Locke, J. (1718), Essay on Money and Bullion, London: for B. Lintot.

Means, G. (1933), "The Present Crisis and a Proposal for Banking Action", Box 1, File: Banking and Currency Reform, The Papers of Gardiner C. Means, Franklin Roosevelt Library, Hyde Park, New York.

Menger, C. (1892), The Origin of Money.

Minsky, H. (1986), Stabilizing an Unstable Economy, New Haven, Connecticut: Yale University Press.

Montague, C. (1952), Spirit of the Laws, Great Books Collection, Encyclopedia Britannica, Vol. 38.

Naumann, F. (1915), Mitteleuropa, Berlin: G. Reimer.

Neumeyer, P. and Perri, F. (2005), "Business Cycles in Emerging Economies: The Role of Interest Rates", Journal of Monetary Economics, 52, 345-380.

O'Brien (2000), "Estimating the Value and Interest Rate Risk of Interest-Bearing Transactions Deposits", Working Paper, Board of Governors of the Federal Reserve System.

Paine, T. (1796), Decline and Fall of English System of Finance, in M.D. Conway, ed., The Writings of Thomas Paine, Vol. 3, 1967, NY: AMS.

Peruzzi, E. (1985), Money in Ancient Rome, pp. 9-10, Florence: Academia Toscana Di Sciencze E Lettere. 
Phillips, R. (1994), The Chicago Plan $\&$ New Deal Banking Reform, M.E. Sharpe.

Pope Pius XI (1931), Quadragesimo Anno, available at:

http://www.osjspm.org/cst/qa.htm.

Pozsar, Z., Adrian, T., Ashcraft, A. and Boesky, H. (2010), "Shadow Banking", Federal Reserve Bank of New York Staff Reports, No. 458.

Quiggin, A.H. (1949), Survey of Primitive Money, London: Metheun.

Randall, J. (1937), The Civil War and Reconstruction, Boston: Heath \& Co., 2nd edition 1961, edited by D. David.

Reinhart, C. and Rogoff, K. (2009), This Time Is Different: Eight Centuries of Financial Folly, Princeton and Oxford: Princeton University Press.

Ricardo, D. (1824), Plan for Establishing of a National Bank, London: J. Murray.

Ridgeway, W. (1892), Origin of Metallic Weights and Standards, Cambridge.

Rogers, J. (1929), The Process of Inflation in France 1914-192\%, New York: Columbia University Press.

Rogoff, K. (1998), "Blessing or Curse? Foreign and Underground Demand for Euro Notes", Economic Policy: A European Forum, 26, 261-290.

Schacht, H. (1967), The Magic of Money, translation by P. Erskine, London: Oldbourne.

Schmitt-Grohé, S. and Uribe, M. (2003), "Closing Small Open Economy Models", Journal of International Economics, 61, 163-185.

Schmitt-Grohé, S. and Uribe, M. (2004), "Optimal Fiscal and Monetary Policy under Sticky Prices", Journal of Economic Theory, 114, 198-230.

Schuckers, J. (1874), Finances and Paper Money of the Revolutionary War, Philadelphia: John Campbell.

Schularick, M. and Taylor, A. (2012), "Credit Booms Gone Bust: Monetary Policy, Leverage Cycles, and Financial Crises, 1870-2008", American Economic Review, 102(2), 1029-1061.

Shaw, W. (1896), The History of Currency, 1252-1896, Putnams, reprinted by New York: A.M. Kelley, 1967.

Simons, H. et al. (1933), "Banking and Currency Reform", manuscript, printed in Warren Samuels, ed., Research in the History of Economic Thought and Methodology, Archival Supplement, Volume 4, Greenwich, CT: JAI Press.

Simons, H. (1946), "Debt Policy and Banking Policy", Review of Economic Statistics, 28(2), 85-89. 
Simons, H. (1948), Economic Policy for a Free Society, Chicago: University of Chicago Press.

Smith, A. (1776), The Wealth of Nations, Great Books, Encyclopedia Britannica, University of Chicago Press, Vol. 39, 1952.

Soddy, F. (1926), Wealth, Virtual Wealth, and Debt, 2nd American Edition, 1933, New York: E.P. Dutton.

Soddy, F. (1933), Money versus Man, New York: Dutton.

Soddy, F. (1943), The Arch Enemy of Economic Freedom, London: Self-published.

Studenski, P. and Kroos, H. (1952), Financial History of the United States, New York: McGraw Hill.

Tobin, J. (1985), "Financial Innovation and Deregulation in Perspective", Bank of Japan Monetary and Economic Studies, 3, 19-29.

Ueda, K. and Brooks, R. (2011), "User Manual for the Corporate Vulnerability Utility: The 4th Edition", International Monetary Fund.

Van den Heuvel, S. (2005), "The Bank Capital Channel of Monetary Policy", Working Paper, Wharton School, University of Pennsylvania.

Van den Heuvel, S. (2008), "The Welfare Cost of Bank Capital Requirements", Journal of Monetary Economics, 55(2), 298-320.

Veblen, T. (1921), The Engineers and the Price System.

Werner, R. (2005), New Paradigm in Macroeconomics, New York: Palgrave/Macmillan.

White, M. (1998), "Why Don't More Households File for Bankruptcy?", Journal of Law, Economics and Organization, 14(2), 205-231.

Whittlesey, C. (1935), "Banking and the New Deal", Public Policy Pamphlet No. 16, Chicago: University of Chicago Press.

Wicksell, K. (1906), Lectures on Political Economy, Volume Two: Money, Lionel Robbins, ed., London: Routledge and Sons, Ltd.

Yamaguchi, K. (2011), "Workings of a Public Money System of Open Macroeconomics: Modeling the American Monetary Act Completed", Working Paper.

Zarlenga, S. (2002), The Lost Science of Money, Valatie, NY: American Monetary Institute. 
Figure 1. Changes in Bank Balance Sheet in Transition Period (percent of GDP)
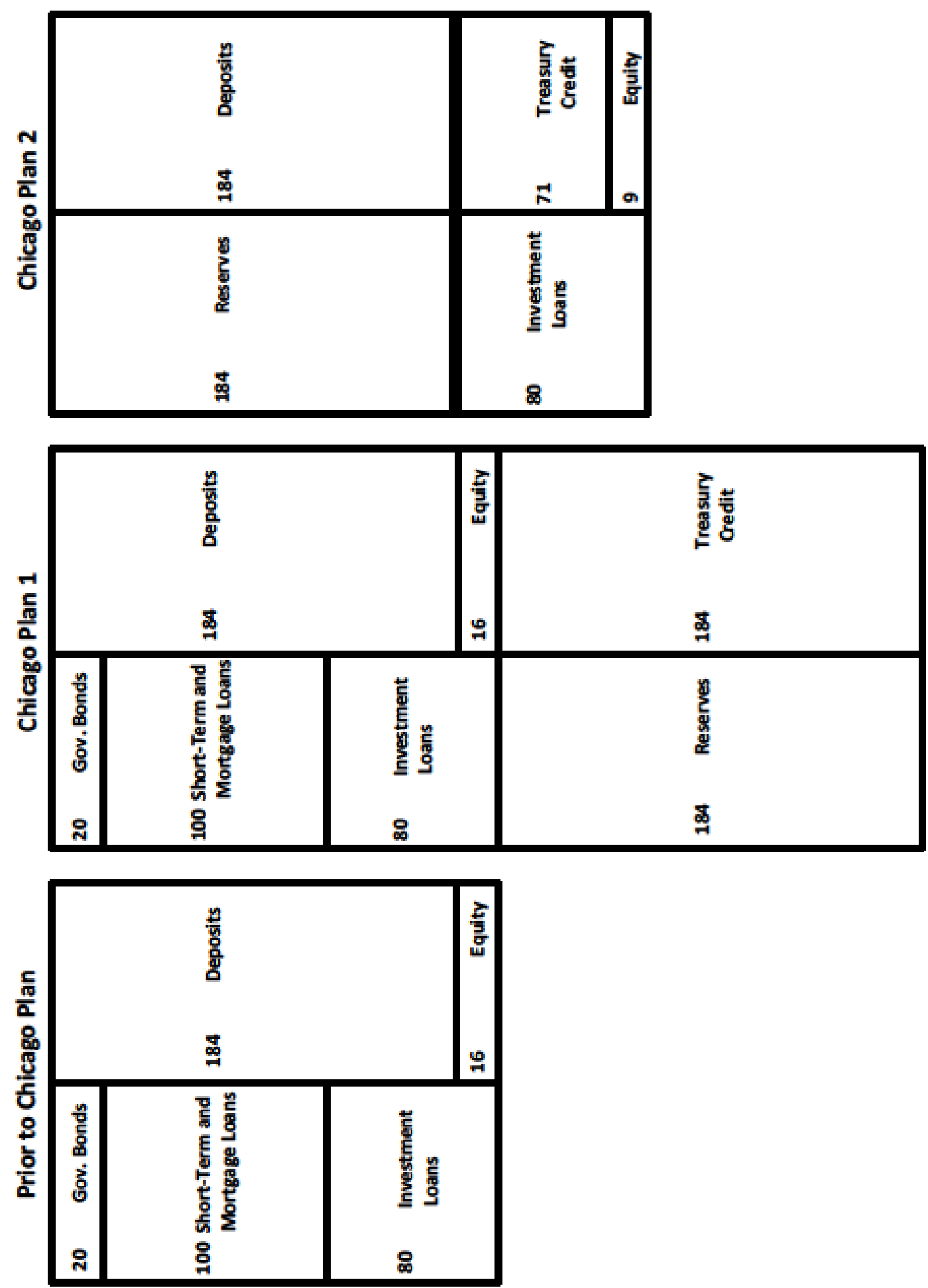
Figure 2. Changes in Government Balance Sheet in Transition Period (percent of GDP)
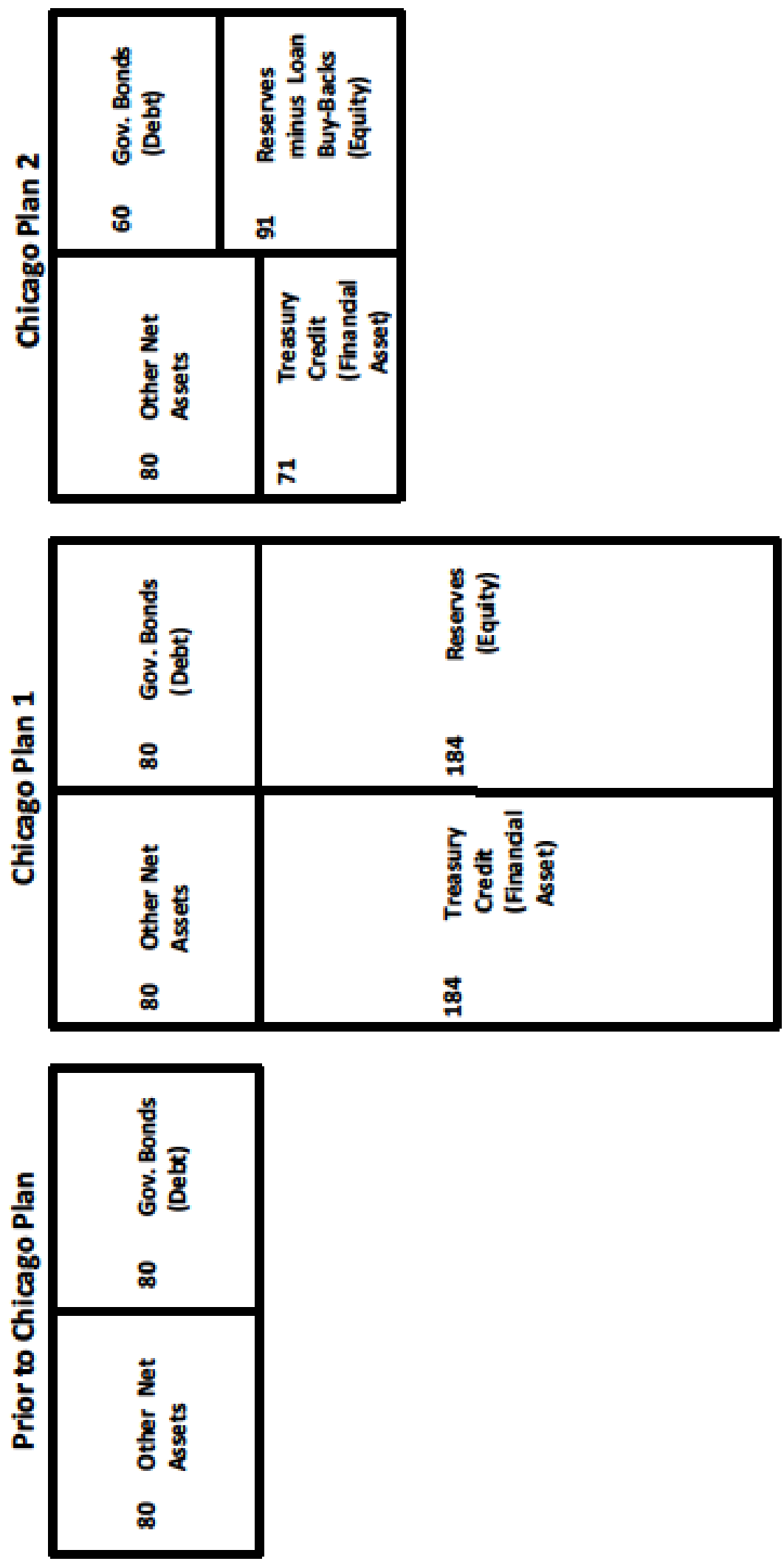

(CInternational Monetary Fund. Not for Redistribution 
Figure 3. Changes in Bank Balance Sheet - Details (percent of GDP)
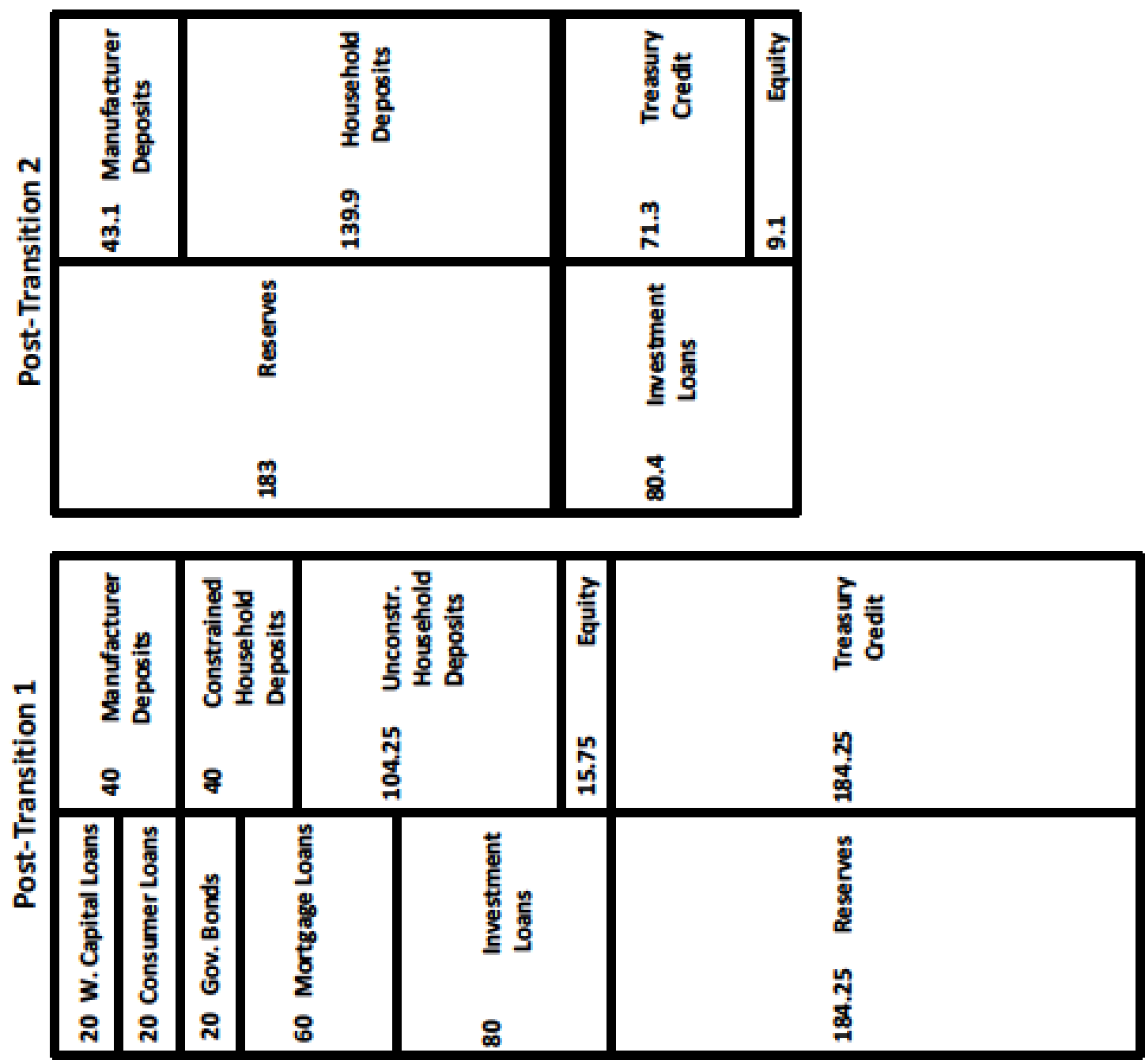

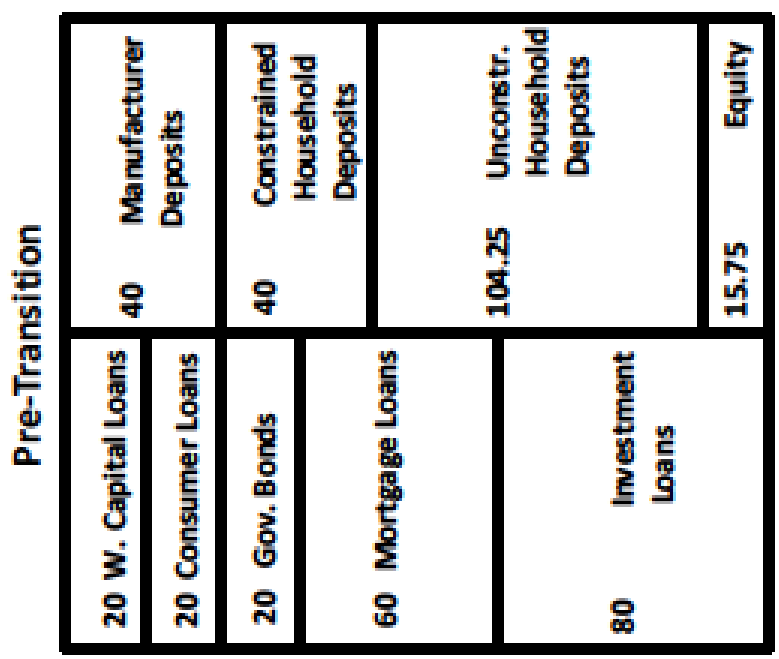


Figure 4. Transition to Chicago Plan - Bank Balance Sheets
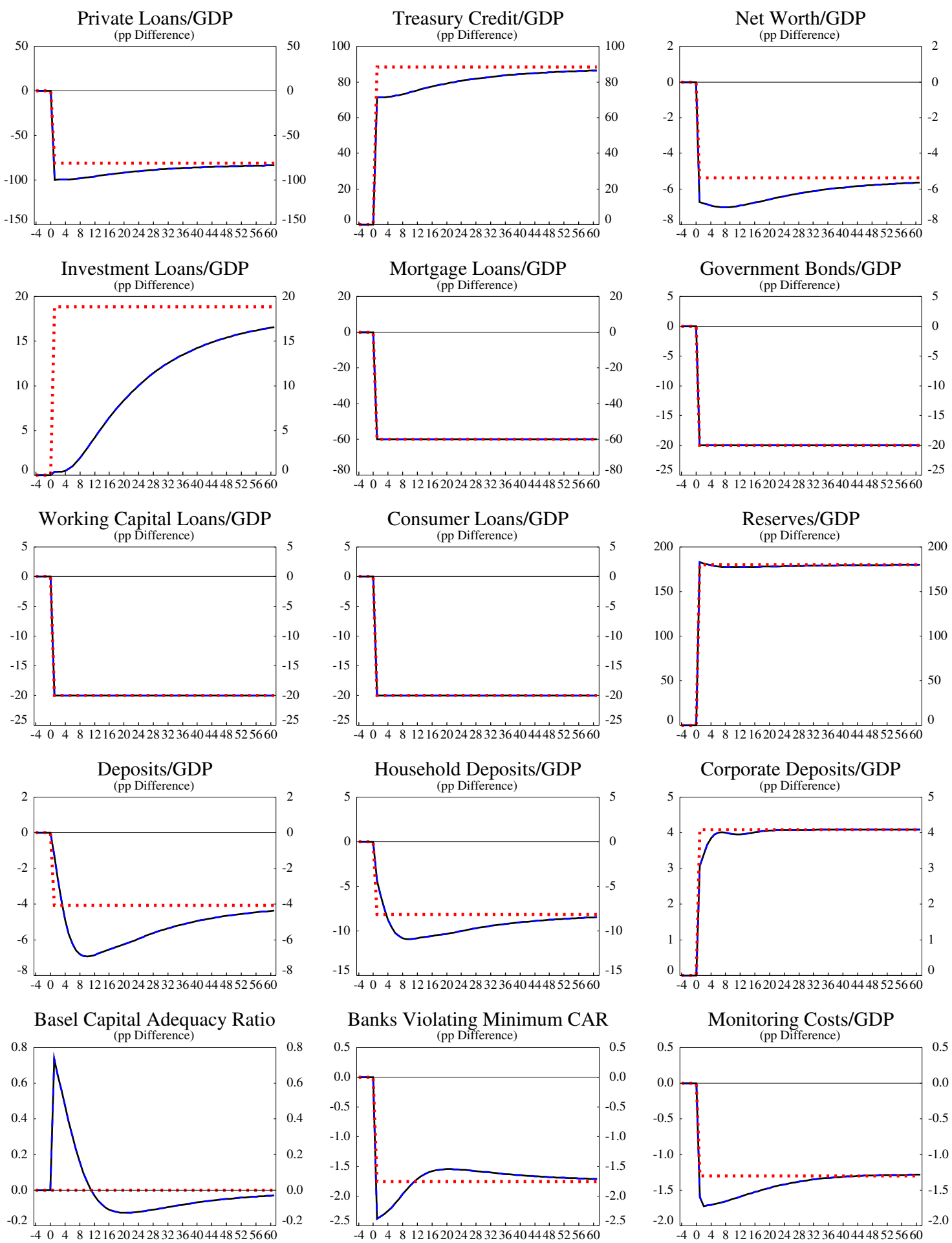
Figure 5. Transition to Chicago Plan - Main Macroeconomic Variables
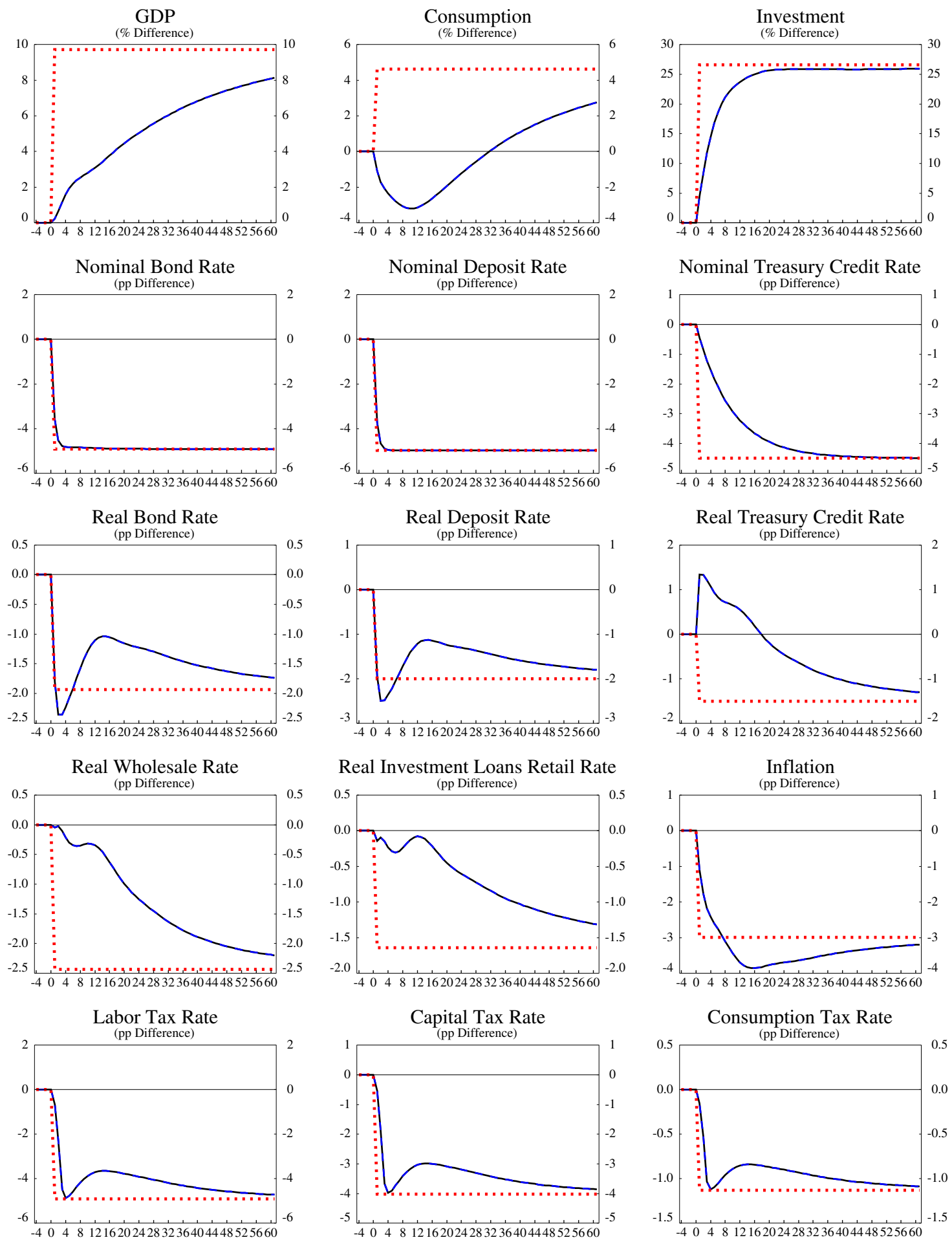
Figure 6. Transition to Chicago Plan - Fiscal Variables
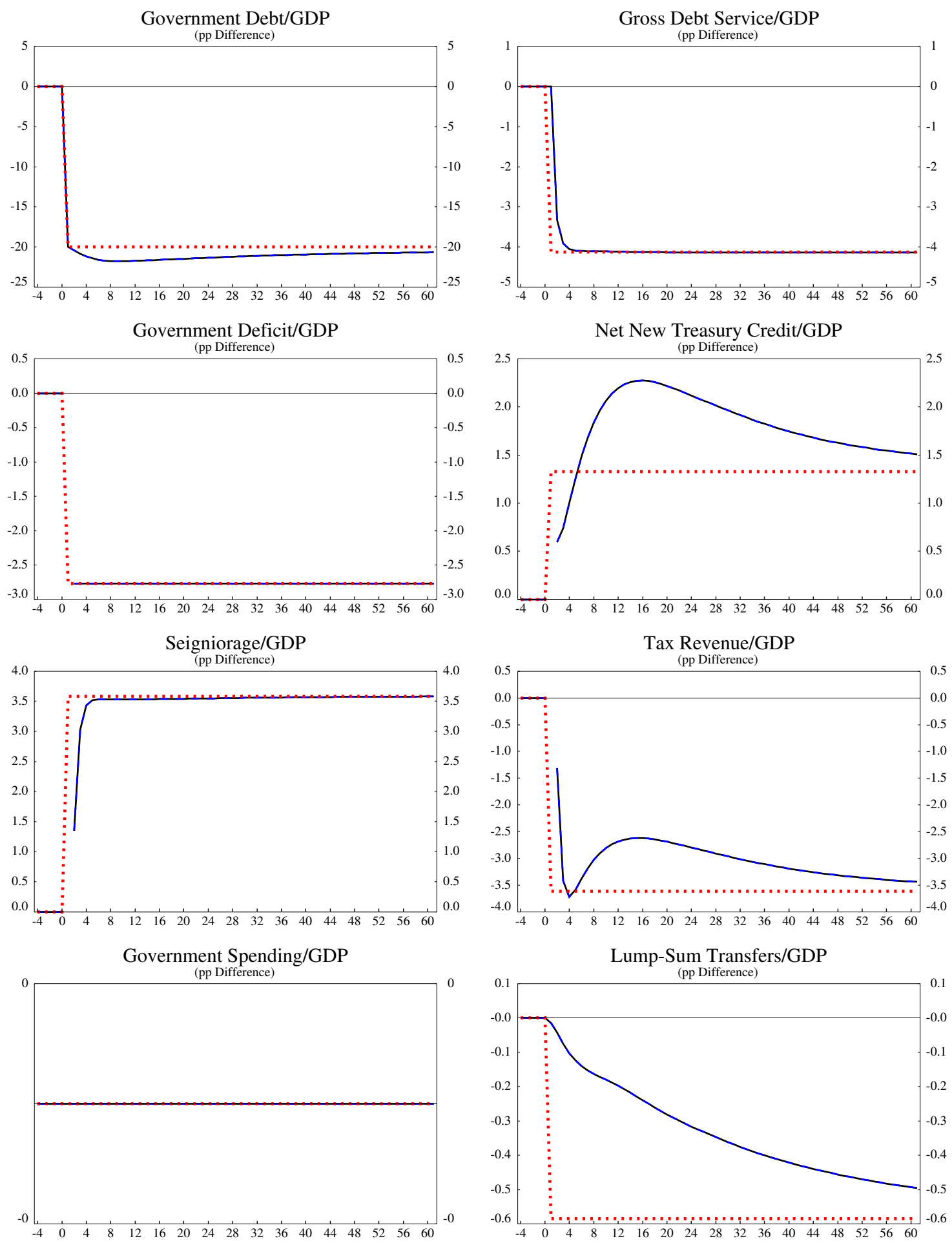
Figure 7. Business Cycle Properties Pre-Transition versus Post-Transition
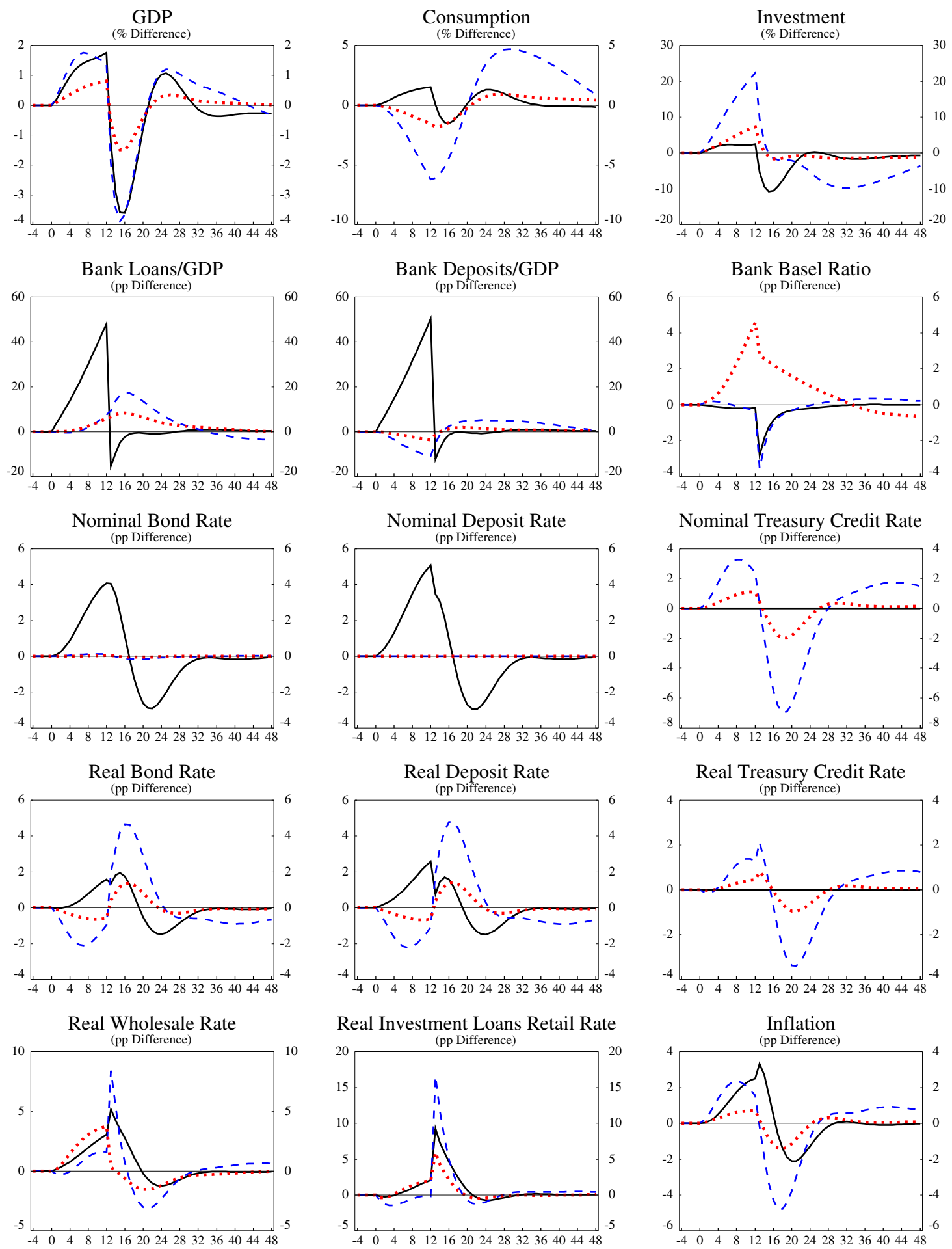

${ }_{-}=$Pre-Transition, $--_{-}=$Post-Transition, $p_{\ell}=0, \ldots=$ Post-Transition, $p_{\ell}=8$ 